\title{
20. LATE OLIGOCENE TO LATE PLIOCENE BENTHIC FORAMINIFERS FROM DEPTH TRAVERSES IN THE CENTRAL INDIAN OCEAN ${ }^{1}$
}

\author{
Anne Boersma ${ }^{2}$
}

\begin{abstract}
Late Oligocene to late Pliocene vertical water-mass stratification along depth traverses in the northern Indian Ocean is depicted in this paper by benthic foraminifer index faunas. During most of this time, benthic faunas indicate well-oxygenated, bottom-water conditions at all depths except under the southern Indian upwelling and in the Pliocene in the southern Arabian Sea.

Faunas suggest the initiation of lower oxygen conditions at intermediate depths in the northern Indian Ocean beginning in Oligocene Zone P21a. Lower oxygen conditions intensified during primary productivity pulses, possibly related to increased upwelling vigor, in the latest Oligocene and throughout most of the late middle through late Miocene. During times of elevated primary production, there may be more oxygen flux into sedimentary pore waters and the shallow infaunal habitat may become more oxygenated.

One criterion for locating the source of "new" water masses is vertical homogeneity of benthic foraminifer indexes for well-oxygenated water masses from intermediate through abyssal depths. In the northern Mascarene Basin, this type of faunal homogeneity with depth corroborates the proposal that the northern Indian Ocean was an area of sinking well-oxygenated waters through most of the Miocene before Zone N17.

Oxygenated, possibly "new" intermediate-water masses in the low- to middle-latitude Mascarene and Central Indian basins first developed in the late Oligocene. These well-oxygenated waters were probably more fertile than the Antarctic Intermediate Waters (AAIW) that cover intermediate depths in these areas today. Production of intermediate waters more similar to modern AAIW is indicated by the sparse benthic population of epifaunal rotaloid species in the northern Mascarene Basin during middle Miocene Zone N9 and from early through late Pliocene time.

Deep-water characteristics are more difficult to interpret because of the extensive redeposition at the deeper sites. Redeposited intermediate, rather than shallow, water fossils and erosion from north to south in the Mascarene Basin are incompatible with the sluggish circulation from south to north through the western Indian Ocean basins today. Such erosion could result from the vigorous sinking of an intermediate-depth water mass of northern origin.

Before late Oligocene Zone P22, benthic faunas indicate a twofold subdivision of the troposphere, with the boundary between upper and lower well-oxygenated water masses located from 2500-3000 mbsl. No characteristic bottom-water fauna developed before the end of late Oligocene Zone P22.

Deep and abyssal benthic indexes suggest the development of water masses similar to those of the present day in the latest Miocene. Faunas containing deep-water benthic indexes, including the uvigerinids, suggestive of a water mass similar to modern Indian Deep Water (IDW), appeared during the late Miocene in the northern Mascarene and Central Indian basins. In the early Pliocene, this deep-water fauna was found only in the Central Indian Basin, whereas a fauna typical of modern Antarctic Bottom Water (AABW) spread through deep waters at $2800 \mathrm{mbsl}$ in the Mascarene Basin. By late Pliocene Zone N21, however, deep-water faunas similar to their modern analogs were developed in both the eastern and western basins.

Abyssal faunas, studied only in the Mascarene Basin, show more or less similarity to those under modern AABW. Bottom-water faunas containing Nuttallides umbonifera or Epistominella exiguua were first differentiated at the end of Zone P22, then appeared episodically during the early Miocene. These AABW-type faunas reappeared and migrated updepth into deep waters during the glacial episodes at the end of the Miocene and at the beginning of the Pliocene. By late Pliocene Zone N21, however, a bottom-water fauna similar to that under eastern Indian Bottom Water (IBW) developed in the Mascarene Basin. Modern bottom-water characteristics of the Mascarene Basin must have developed after Zone N21.
\end{abstract}

\section{INTRODUCTION}

Benthic foraminifers were recovered at 12 sites cored during Ocean Drilling Program (ODP) Leg 115 to the north central Indian Ocean. Benthic faunas from all these sites have been discussed previously (Backman, Duncan, et al., 1988). Because these sites penetrated the water column from 1,500 to $4,000 \mathrm{~m}$ below sea level (mbsl), they sampled the major bathymetric zones and presumably their unique bottom conditions and water masses. In this paper I will use quantitative study of the benthic foraminifers along several traverses to describe faunal segre-

\footnotetext{
${ }^{1}$ Duncan, R. A., Backman, J., Peterson, L. C., et al., 1990. Proc. ODP, Sci. Results, 115: College Station, TX (Ocean Drilling Program).

2540 Gate Hill Road, Stony Point, NY 10980, U.S.A.
}

gation through depth. Environmental index faunas will be used to suggest the evolution of paleoenvironments in intermediate, deep, and abyssal areas of the central equatorial Indian Ocean. Key questions involve the differing histories of low-oxygen northern water vs. well-oxygenated intermediate water of southern origin; the source of deep waters before the evolution of true North Atlantic Deep Water (NADW); the possible effects of the increasing closure of the Middle Eastern Strait; and the effects of global glaciation.

Stable isotope analyses provided by N. Shackleton (see Boersma and Mikkelsen, this volume) and Woodruff et al. (this volume), augmented by published data (Vincent et al., 1985; Oberhänsli, 1986; Keigwin and Corliss, 1986; Woodruff and Savin, 1989) are evoked to test interpretations of water-mass stratification and benthic paleoenvironment suggested by the benthic foraminifers. 


\section{METHODS}

In the northwest central Indian Ocean, a traverse from 1500 to $3800 \mathrm{~m}$ down the Mascarene Ridge into the Mascarene Basin (Fig. 1) included Site 707 (1541 m), Site 709 (3038 m), and Site $710(3812 \mathrm{~m})$. This data base was augmented by sample sets from other western deep and intermediate-depth sites, including Sites 237, 238, 236, 241, and 219 (Table 1).

To the east, depth-graded sites were recovered both from the southern (Site 713) and northeast Chagos-Laccadive Ridge (Sites 714 and 715). Additional samples were studied from the southwest of India in the southeastern Arabian Sea (Site 219) and on Ninetyeast Ridge, including Sites 217 and 218 in the Bay of Bengal, 215 and 253 in the eastern Central Indian Basin, and 214 and 216 in the western Wharton Basin (Table 1).

Samples of $20 \mathrm{~cm}^{3}$ were washed on a $63-\mu \mathrm{m}$ sieve and air dried. Approximately $1 \mathrm{mg}$ of each sample was used for counts of all species in the $>63-\mu \mathrm{m}$ size fraction, thus producing an approximation of benthic abundance in a standardized sample. Benthic foraminifers were counted according to the following scheme: $1=$ present, $2=2$ or more, $3=3-5,4=5-10,6=$ $10-30,7=30-50,8=50-75$, and $9=75-150$. Because benthic foraminifers are not common in most samples, in many instances the numbers represent their true abundance in a sample. Only the bolivinids reached abundances of 6 or greater.

Estimates of abundance were used to determine paleobathymetric index faunas. A species was included in the index fauna
Table 1. Locations and depths of all Indian Ocean sites included in this study.

\begin{tabular}{lll}
\hline & $\begin{array}{c}\text { Latitude, } \\
\text { longitude }\end{array}$ & $\begin{array}{c}\text { Depth } \\
\text { (mbsl) }\end{array}$ \\
\hline 214 & $1^{\circ} \mathrm{S}, 88^{\circ} \mathrm{E}$ & 1761 \\
215 & $8^{\circ} \mathrm{S}, 86^{\circ} \mathrm{E}$ & 5321 \\
216 & $1^{\circ} \mathrm{N}, 90^{\circ} \mathrm{E}$ & 2262 \\
217 & $8^{\circ} \mathrm{N}, 90^{\circ} \mathrm{E}$ & 3030 \\
218 & $8^{\circ} \mathrm{N}, 86^{\circ} \mathrm{E}$ & 3737 \\
219 & $9^{\circ} \mathrm{N}, 72^{\circ} \mathrm{E}$ & 1764 \\
236 & $1^{\circ} \mathrm{S}, 57^{\circ} \mathrm{E}$ & 5146 \\
237 & $7^{\circ} \mathrm{S}, 58^{\circ} \mathrm{E}$ & 1640 \\
238 & $1^{\circ} \mathrm{S}, 70^{\circ} \mathrm{E}$ & 2844 \\
241 & $2^{\circ} \mathrm{S}, 44^{\circ} \mathrm{E}$ & 4054 \\
242 & $15^{\circ} \mathrm{S}, 41^{\circ} \mathrm{E}$ & 2275 \\
253 & $24^{\circ} \mathrm{S}, 87^{\circ} \mathrm{E}$ & 1962 \\
707 & $7^{\circ} \mathrm{S}, 59^{\circ} \mathrm{E}$ & 1541 \\
709 & $3^{\circ} \mathrm{S}, 60^{\circ} \mathrm{E}$ & 3038 \\
710 & $4^{\circ} \mathrm{S}, 60^{\circ} \mathrm{E}$ & 3812 \\
713 & $4^{\circ} \mathrm{S}, 73^{\circ} \mathrm{E}$ & 2090 \\
714 & $5^{\circ} \mathrm{N}, 73^{\circ} \mathrm{E}$ & 2038 \\
715 & $5^{\circ} \mathrm{N}, 73^{\circ} \mathrm{E}$ & 2262 \\
\hline
\end{tabular}

Note: Data from Heirtzler et al. (1977) and Backman, Duncan, et al. (1988).

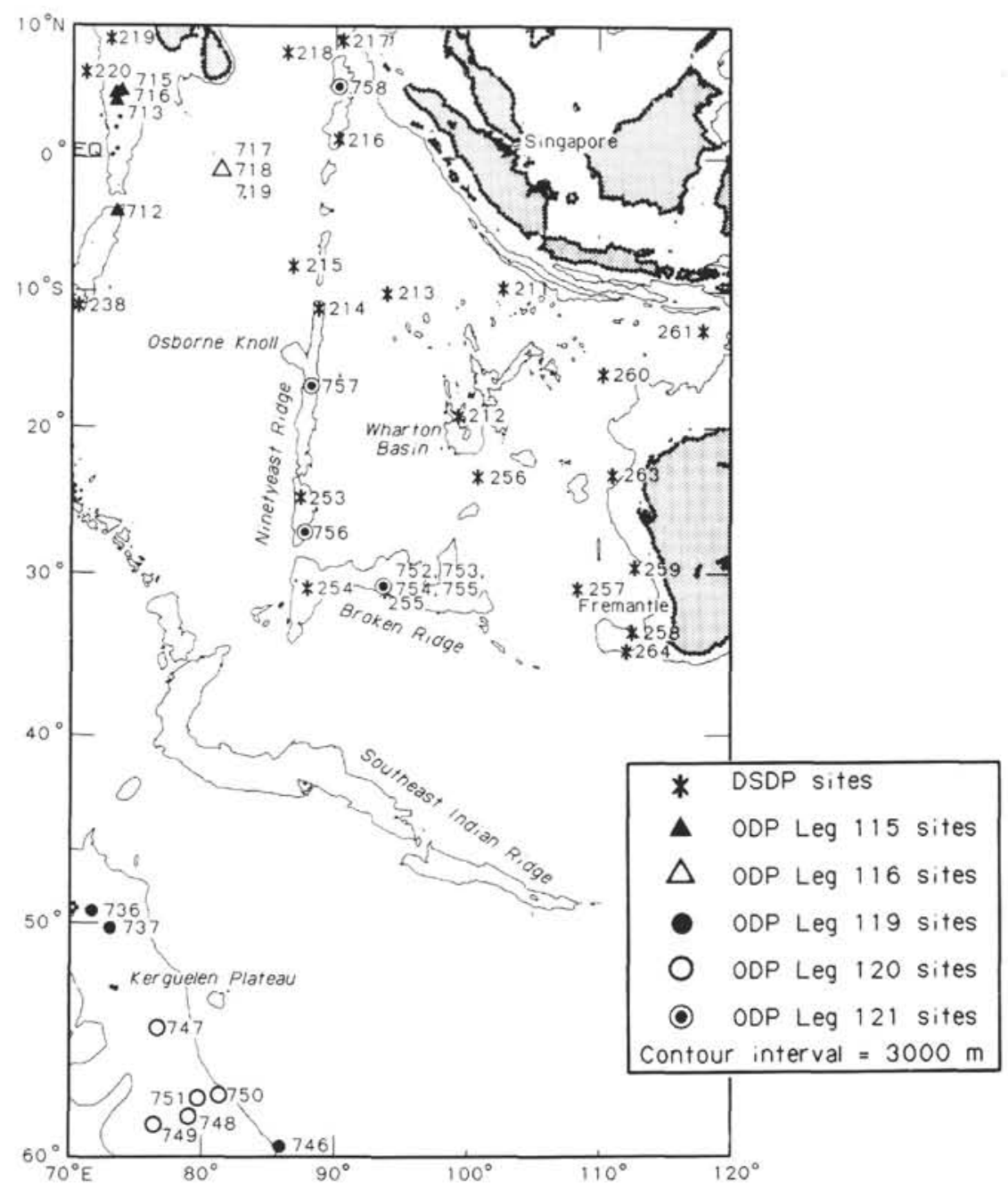

Figure 1. Location map of the eastern Indian Ocean showing DSDP and ODP sites. 
if it (1) occurred in greatest abundance throughout the sample interval, (2) occurred consistently throughout the sample interval, (3) first appeared or disappeared in the sample interval, or (4) transgressed its usual bathymetric range.

Not only the abundance of key species but also the diversity (species richness) and numbers of infauna and epifauna (Corliss and Chen, 1988) are used in this environmental interpretation. The infaunal-epifaunal ratio was computed for all samples from the Leg 115 sites by two methods. Both the numbers (species richness) and abundances of infauna compared with the numbers and abundances of epifauna are tabulated. Although we do not know all the species that belong to these categories, all genera presently assigned to the infauna, whether the deeper or shallower dwelling types, as well as the stilostomellids were attributed to infauna. The epifaunal genera of Corliss and Chen (1988) were counted as epifauna, and all agglutinants were excluded from consideration in this study.

Ten time slices from the Oligocene-Pliocene sequence were chosen for this study because they were represented at the largest number of sites along the two traverses. Because of extensive published reports of largely deep-water Miocene benthic faunas (Woodruff and Douglas, 1981; Woodruff, 1985; Woodruff and Savin, 1989), this study focuses on Oligocene and Pliocene age sediments and the eastern traverse of intermediate-depth sites.

Biostratigraphy (Backman, Duncan, et al., 1988), but no paleomagnetics, formed the basis of inter-site correlation. Therefore, site-to-site correlation of specific events is speculative. Biozonation was confounded by redeposition and hiatuses throughout all sections, with all abyssal samples containing some redeposited materials. Continuous stable isotope records were not produced because of the poor preservation, numerous hiatuses, and low rates of sediment accumulation. Global events recognizable in the stable isotope records, such as the late Miocene carbon shift (Vincent et al., 1980), the late Miocene glacial episode (Elmstrom and Kennett, 1985), and the late Oligocene Zone P22 warming (Boersma and Shackleton, 1977) allowed some intersite correlation.

\section{PALEOENVIRONMENTAL INDEXES}

Paleoenvironmental interpretation requires the use of species with well-established environmental preferences. A number of benthic foraminifer indexes, related to edaphic variables either in the water or in the sediment, are listed in Table 2 . Two types of foraminiferal associations identified in modern settings are useful in an interpretation of past environments: (1) species that occur under specific environmental conditions (Table 2), and (2) groupings of species produced by factor analysis, which are associated with a particular water mass (hereafter called factorspecies, factor-faunas, or factor-associations).

\section{Paleobathymetric Index Species}

In the Indian Ocean data set, there are a large number of species restricted to intermediate-depth, but not deeper, water sites. These include Discanomalina semipunctata, Cassidulinoides cornuta, Uvigerina spinulosa, Rectuvigerina striata, Discorbis villardeboanus, Planulina marialanna, Planulina gigas, Planulina renzi, Astrononion spp., Bulimina glomarchallengeri, Lenticulina nicobarensis, Bolivinita quadrilatera, Bolivina peregrina, Dyocibicides sp., Rectuvigerina spinea, Ceratobulimina pacifica, Planulina ariminensis, Textularia lythostrata, Martinotiella variabilis, Bolivina pseudobeyrichi, Bolivina pseudoplicata, Bolivina villaverniensis, Bolivina serranensis, Bolivina dilatata, Bolivina pukeuriensis, Bolivina finlayi, Bolivina goessi, Heterolepa rugosa, Bolivina tortuosa, Uvigerina porrecta, and Cassidulina ornata.

Species confined to deep or abyssal sites are few, and most are abyssal forms such as E. exiguua, P. quinqueloba, or N. um-
Table 2. Benthic foraminifers and the oceanographic parameters to which their occurrence has been related.

\begin{tabular}{|c|c|c|}
\hline Species/characteristic & Parameter & Reference \\
\hline Bolivinid ornament & Low energy bottom & 5 \\
\hline Bolivina diversity & Low oxygen & 1 \\
\hline Bolivina shape & Low oxygen & 2 \\
\hline Thick, crenulate bolivinids & Moderate oxygenation & 2 \\
\hline Smooth flat bolivinids & Low oxygen & 2 \\
\hline Delicate bolivinids & Lowest oxygen & 2 \\
\hline Shape B. albatrossi & Paleodepth & $3^{*}$ \\
\hline B. aenariensis & $\begin{array}{l}\text { Oxygen minimum, not } \\
\text { organic carbon maximum }\end{array}$ & $22^{*}$ \\
\hline Uvigerinid abundance & More organic carbon & 2 \\
\hline Uvigerinid abundance & More phosphorous & $4^{*}$ \\
\hline Rectuvigerinids & Heightened production & $11^{*}$ \\
\hline Uvigerinid ornament & Paleodepths & 6,7 \\
\hline Uvigerina, Hoeglundina & Solution susceptible & $13^{*}$ \\
\hline$U$. peregrina s.l. & Indian Deep Water & $10^{*}$ \\
\hline $\begin{array}{l}\text { U. peregrina, G. subglobosa, } \\
\text { Pyrgo }\end{array}$ & Old water, infauna & $14^{*}$ \\
\hline Uvigerinids & High sedimentation rate & 15 \\
\hline Trifarina spp. & High salinity & 20 \\
\hline $\begin{array}{l}\text { Uvigerina-E. exiguua- } \\
\text { M. pompilioides- } G \text {. solda- } \\
\text { nii }\end{array}$ & Indian Bottom Water & $26^{*}$ \\
\hline E. ехіguиа & Oxic conditions & 1 \\
\hline E. exiguиa & Specific volume anomaly & $10^{*}$ \\
\hline E. exiguиa, $N$. umbonifera & Lysocline & 16 \\
\hline E. ехіguиa & NADW & $18^{*}$ \\
\hline G. subglobosa, U. peregrina & CPDW & $19^{*}$ \\
\hline Large size $G$. subglobosa & Less corrosive waters & $12^{*}$ \\
\hline $\begin{array}{l}\text { M. sphaeroides, } P \text {. quinque- } \\
\text { loba, N. umbonifera }\end{array}$ & Bottom waters & 15 \\
\hline $\begin{array}{l}\text { P. murrhina, C. wuellerstorfi, } \\
\text { Nuttallides }\end{array}$ & Corrosive bottom water & $8 *, 9$ \\
\hline N. umbonifera & AABW & $8,10,18^{*}$ \\
\hline $\begin{array}{l}\text { N. umbonifera-O. umbonatus, } \\
\text { G. subglobosa }\end{array}$ & Antarctic Bottom Water & $26^{*}$ \\
\hline $\begin{array}{l}\text { E. umbonifera, } P \text {. bulloides, } \\
\text { C. wuellerstorfi }\end{array}$ & AABW & 25 \\
\hline $\begin{array}{l}\text { C. kullenbergi, N. umbonifera, } \\
\text { Gyroidinoides }\end{array}$ & More dissolution resistance & $13^{*}$ \\
\hline Gyroidina, Glomospira & Low oxygen, corrosivity & $21^{*}$ \\
\hline Gyroidina + Hoeglundina & Poor ventilation, noncorrosive & $21^{*}$ \\
\hline Lenticulinid ornament & Paleodepths & 6 \\
\hline Infauna & $\begin{array}{l}\text { Higher organic carbon, low } \\
\text { oxygen }\end{array}$ & $17^{*}$ \\
\hline Epifauna & Oxic conditions & $17^{*}$ \\
\hline Articulina, miliolids & Low ph minerals & $21^{*}$ \\
\hline Cibicidids replace eponidids & $\begin{array}{l}\text { Terrigenous, not marine, } \\
\text { organic matter }\end{array}$ & \\
\hline Smooth cassidulinids & Low oxygen & $2,5,16$ \\
\hline Bulimina spp. & $\begin{array}{l}\text { Low oxygen, high organic } \\
\text { carbon, pollution }\end{array}$ & $24^{*}$ \\
\hline $\begin{array}{l}\text { C. wuellerstorfi, G. subglobosa, } \\
\text { C. kullenbergi }\end{array}$ & Highly oxic NADW & 25 \\
\hline M. barleeanum, C. wuellerstorfi & $\begin{array}{l}\text { Moderately high surface-water } \\
\text { productivity }\end{array}$ & 25 \\
\hline O. umbonatus, C. kullenbergi & $\begin{array}{l}\text { Moderately low surface-water } \\
\text { production }\end{array}$ & 25 \\
\hline $\begin{array}{l}\text { Astrononion, M. barleanuum, } \\
\text { Uvigerina }\end{array}$ & $\begin{array}{l}\text { Corrosive, high surface } \\
\text { productivity }\end{array}$ & 27 \\
\hline \multirow[t]{2}{*}{ Astrononion } & $\begin{array}{l}\text { Corrosive, less highly produc- } \\
\text { tive }\end{array}$ & 27 \\
\hline & & 27 \\
\hline
\end{tabular}

Notes: Relations based on core-top studies are indicated with an asterisk $\left({ }^{*}\right)$. References are as follows: 1, Poag and Low, 1984; 2, Douglas, 1981; 3, Gary, 1985; 4, Lutze and Coulbourn, 1984; 5, Hendrix, 1958; 6, Boersma, 1984; 7, Boersma, 1985b; 8, Bremer and Lohmann, 1982; 9, Tjalsma and Lohmann, $1983 ; 10$, Peterson, 1984; 11, Lutze, 1977; 12, Corliss, 1980; 13, Corliss and Honjo, 1980; 14, Murray, 1973; 15, Boersma, 1985c; 16, Burke, 1981; 17, Corliss and Chen, 1988; 18, Schnitker, 1974; 19, Lohmann, 1978; 20, Oberhänsli et al., 1983; 21, Cita and Zocchi, 1978; 22, Saunders et al., 1985; 23 , Poag, 1981; 24, Seiglie, 1968; 25, Woodruff and Savin, 1989; 26, Corliss, 1979; 27, Woodruff and Douglas, 1981. 
bonifera that migrate updepth during discrete episodes in both the Paleogene and Neogene. Species with upper depth limits in deep-water sites were not found, but the following species were largely restricted to deep-water or abyssal sites: Pullenia quinqueloba, Melonis sphaeroides, N. umbonifera, E. exiguua, Heterolepa grimsdalei, smooth Buliminella sp., Favocassidulina fava, and Martinotiella cojimarensis.

\section{Size of Globocassidulina subglobosa}

To test the causal relationship between increased size of Globocassidulina subglobosa and increased carbonate saturation proposed for Indian Ocean populations by Corliss (1979), three sizes of G. subglobosa were counted separately at Sites 707, 709, 710 , and 713. Small-sized forms occurred in the $>63-<125-\mu \mathrm{m}$ size fraction, and medium-sized forms were approximately twothirds the size of large forms, with the latter categories both occurring in the $>250-\mu \mathrm{m}$ size fraction. Plots of relative abundance of the two extreme size classes and the numeric expression of preservation are shown in Figure 2.

In both the Oligocene and Neogene data sets at shallow and deep sites, there is a direct relation between estimates of good carbonate preservation and higher abundances of large size $G$. subglobosa, but no apparent relation between better preservation and small-size G. subglobosa. Although this does not confirm the hypothesis of Corliss (1979), it does corroborate his supposition that the abundance of large G. subglobosa is directly related to improved carbonate preservation in the western Indian Ocean.

\section{Temporal and Spatial Evolution of the Infaunal-Epifaunal Ratio}

The abundance of infauna in the modern North Sea has been related to conditions where the flux of organic carbon is higher. Inversely, modern epifauna in this basin proliferate under well-oxygenated conditions when the organic carbon flux is lower. The ratio between infauna and epifauna may, therefore, provide an index of more or less oxygenated bottom conditions and relative rates of organic carbon accumulation in ancient sediments (Corliss and Chen, 1988).

Faunas from Leg 115 traverses revealed two main trends in the infaunal-epifauna ratio (Figs. 3, 4, and 6). First, infaunal numbers parallel diversity at high and low sedimentation rate sites. And, second, infauna have predominated at all depths throughout the late Paleogene and most of the Tertiary, even in faunas that suggest well-oxygenated conditions (Table 2). The shallower the site, the greater this predominance. Epifauna predominate only in deep-water and abyssal areas after the early Pliocene.

Figures 3, 4, and 6 demonstrate the elegant correlation and parallelism between infaunal number and diversity (species richness) at intermediate-depth Sites 714 (relatively high sediment accumulation rates) and 707 (low accumulation rates) and deepwater Site 709. At Site 219 in the southern Arabian Sea, diversity is always maximal and infauna outnumber epifauna by as much as $4: 1$. Clearly, a large portion of the diversity is made up by infaunal species in the central Indian Ocean.

The infaunal-epifaunal ratios indicate the relative scarcity of epifauna before the Pliocene. Throughout the late Paleogene and Neogene, epifauna only increase in number: (1) during Zone P21 before the spread of lower oxygen index species in the Mascarene and Central Indian basins; $(2)$ in the Pliocene at deep and abyssal sites in the Mascarene Basin; (3) during episodes of redeposition; or (4) during Zones N9 and N22 at Site 707. By early Pliocene Zone N18, epifaunal numbers increase first in abyssal areas. By Zone N21, epifauna are more abundant than infauna at deep- and bottom-water sites and episodically dominate faunas at intermediate-depth Site 707 .

\section{PALEOCLIMATIC EVENTS DURING TIME SLICES}

Paleoceanographic interpretation of the late Paleogene-Neogene time slices is based on oxygen and carbon isotope analysis of planktonic and benthic foraminifers from the tropical Indian Ocean (Vincent et al., 1985; Oberhänsli, 1986; Woodruff et al., 1989; Woodruff and Savin, this volume; Boersma and Mikkelsen, this volume).

\section{Late Oligocene Time Slices P21 and P22}

Late Oligocene data are derived from Site 253 located at middle latitudes at the southern end of Ninetyeast Ridge. Benthic oxygen isotope data indicate a gradual enrichment through the early Oligocene, followed by an enrichment event near the top of Zone NP23. At the Oligocene/Miocene boundary both benthic and planktonic oxygen isotope values become depleted by just under $1 \%$. The surface to bottom carbon isotope gradients increase slightly in the latest Oligocene.

A benthic carbon isotope enrichment event at intermediatedepth sites at the Oligocene/Miocene boundary results in uniform carbon isotope values through a depth range of 1500-2500 mbsl. At Site 714 in the southern Indian upwelling zone, despite little change in benthic oxygen isotope values, benthic carbon isotope data from Planulina renzi indicate a $0.5 \%$ enrichment at the beginning of the Miocene (Boersma and Mikkelsen, this volume). An enrichment of almost identical values is registered by Cibicidoides across the Oligocene/Miocene boundary at Site 253 (Oberhänsli, 1986). Little change occurs in values of Cibicidoides at Site 707, which were already slightly enriched relative to those at other sites (Boersma and Mikkelsen, this volume). Because of variability in the differences of the values of Oridorsalis vs. the cibicidids, the Indian Ocean data of Vincent et al. (1985) are presently not comparable. Those data do, however, demonstrate the same pattern as the cibicidid data. There is little change at Mascarene Basin Site 237, immediately adjacent to Site 707, but an excursion is recorded at intermediate-depth Sites 214 and 216 on Ninetyeast Ridge. In summary, by the beginning of the Miocene, cibicidid carbon isotope values in western sites from 1500 to $2500 \mathrm{mbsl}$ approximate $1.6 \% 0-1.7 \%$. This increased the intermediate- to deep-water carbon isotope gradient to $1 \%$.

\section{Early Miocene Time Slices N4 and N9}

The lack of stable isotope analyses from early Miocene Zones N4-N7 reflects generally poor sediment preservation and the small size of benthic fossils. The major shift between early Miocene Zone N4 and middle Miocene Zone N9 involves carbon isotope values that become more positive at the surface and bottom during the Epoch 16 carbon shift (Vincent et al., 1985). This shift is apparent also in the cibicidid data from Site 709 (Woodruff et al., this volume) and in the difference between cibicidid values from Zones $\mathrm{CN} 1$ (N4 time slice) to CN4 (N9 time slice) at Site 714 (Boersma and Mikkelsen, this volume). This excursion has been attributed to the extraction of organic carbon from the ocean into another reservoir (Vincent et al., 1985).

The Indian Ocean may have served as the source for deep waters to both the Atlantic and Pacific oceans at this time (Woodruff and Savin, 1989). Intermediate- and deep-water carbon isotope values in all three oceans suggest "aging" of water from the Indian Ocean to the deep Pacific and Atlantic. These authors propose that a Tethyan Indian Saline Water, mixed with circumpolar water in the Antarctic, served as the source of deep water to the world's oceans. A similar process operative from middle to late Miocene was proposed by Johnson (1985).

\section{Time Slice N17}

The late Miocene Epoch 6 carbon shift and the glacial buildup at the end of the Miocene are discernible in Indian Ocean rec- 

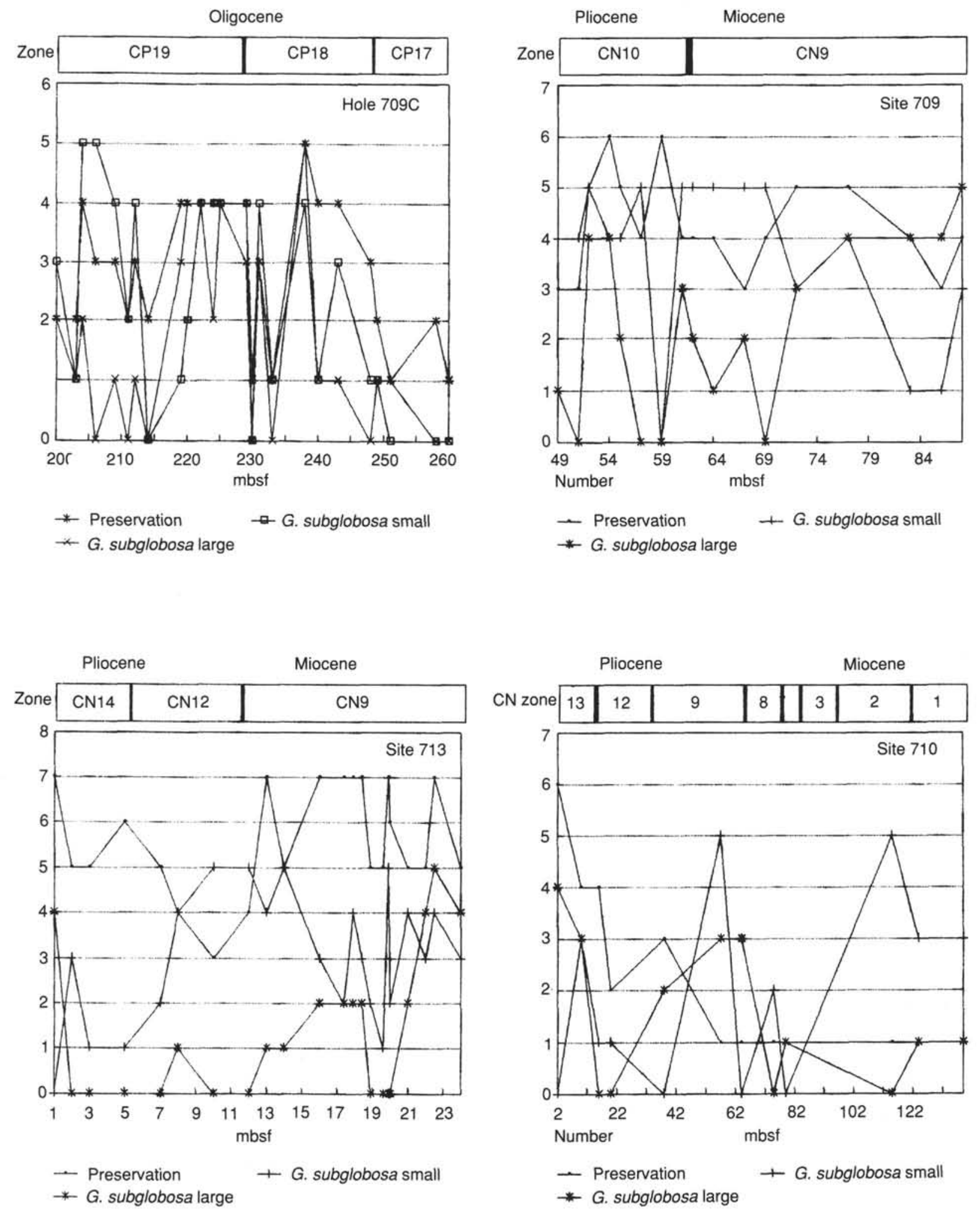

Figure 2. Abundance of large- vs. small-sized Globocassidulina subglobosa at three sites in the western Indian Ocean. The comparison of size with carbonate preservation, as indicated in Tables 11, 15,16, and 17, tests the idea that larger sized G. subglobosa is related to increased carbonate saturation (Corliss, 1979). Biostratigraphic zonation from Backman, Duncan, et al. (1988). 
Oligocene

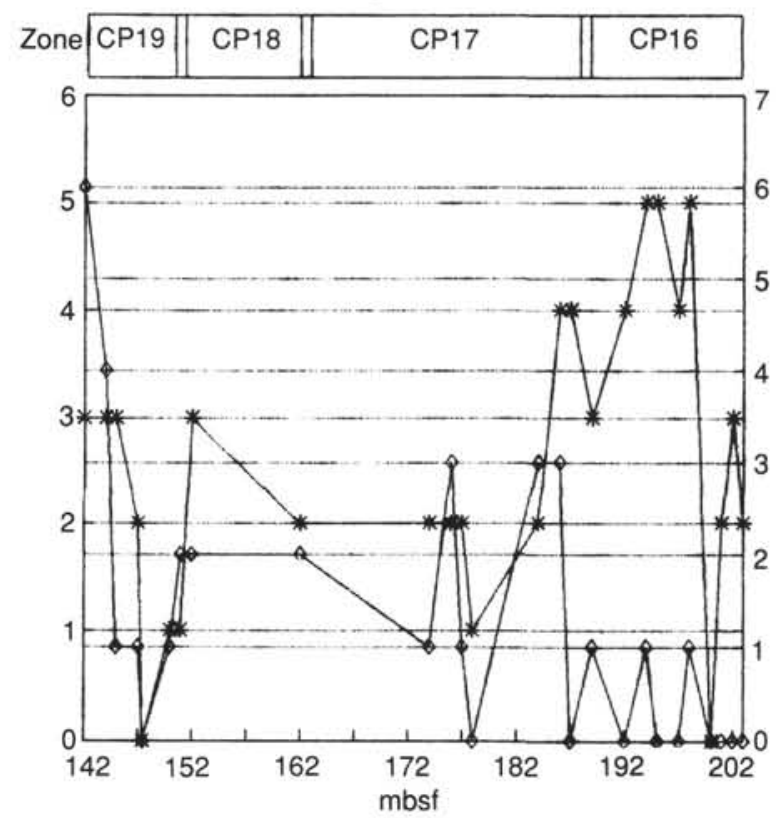

* o. umbonatus $\rightarrow$ Total uvigerinids
Oligocene

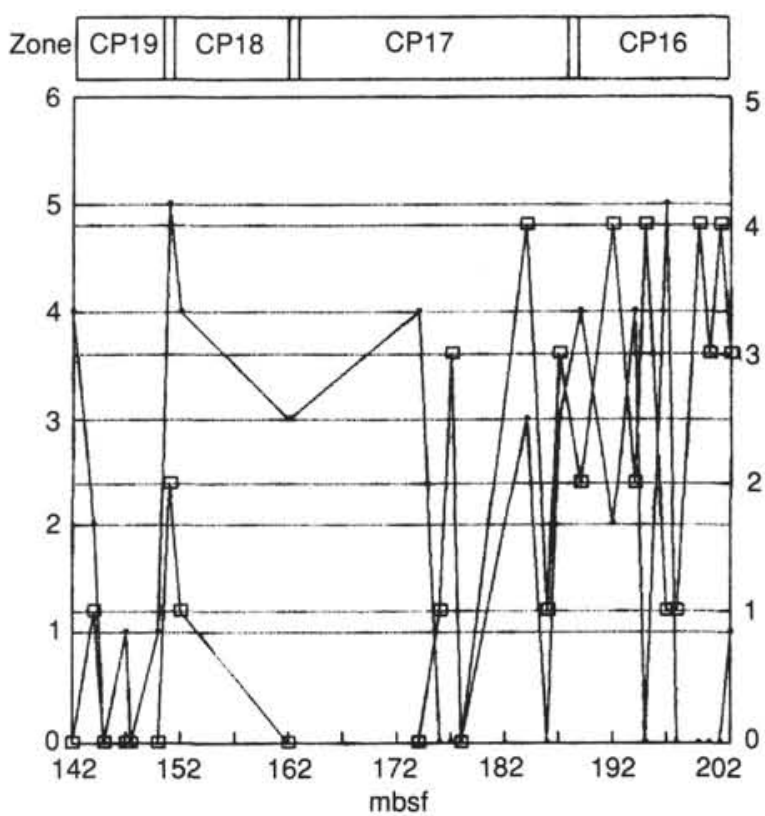

- B. tectiformis $\because 0$. mexicana

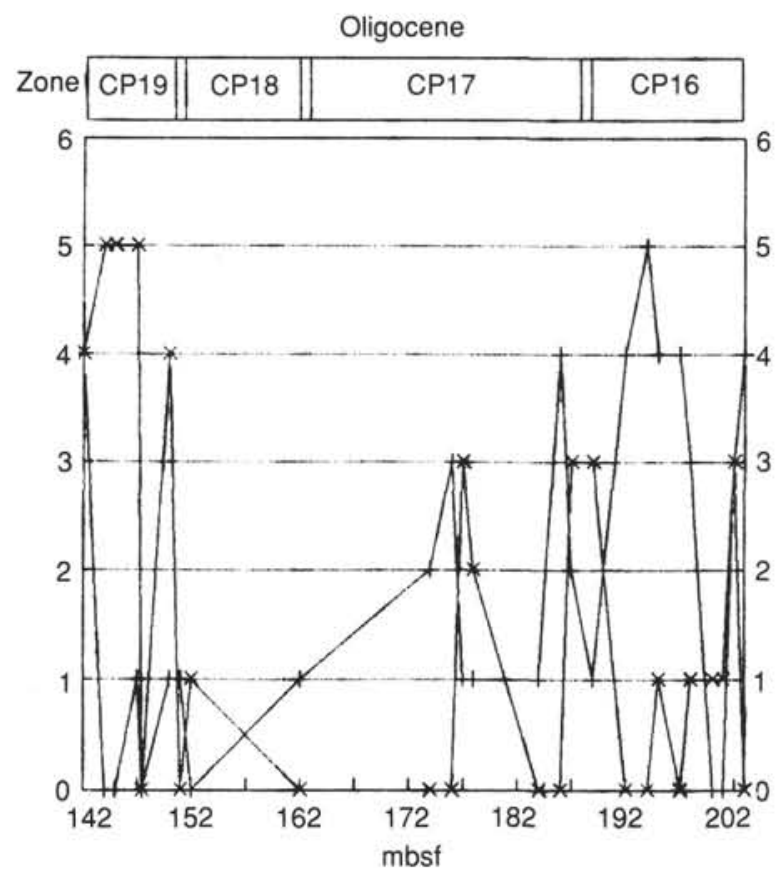

+ C. havanensis $\quad$ S. gracillima

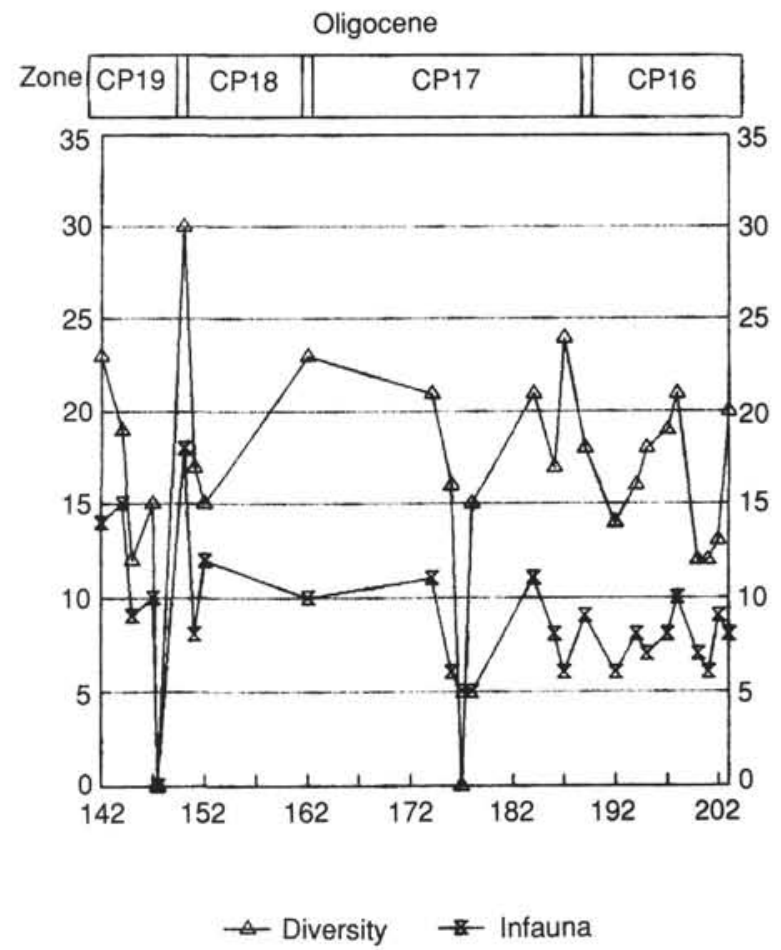

Figure 3. Relative abundances of most common benthic foraminifers during the Oligocene at Site 707. Species include Osangularia mexicana, Uvigerina spp., Bolivina tectiformis, Oridorsalis umbonatus, Cibicidoides havanensis, and Stilostomella gracillima. Total infaunal number is plotted against total diversity for each sample in Table 3. Zonation from Backman, Duncan, et al. (1988). 

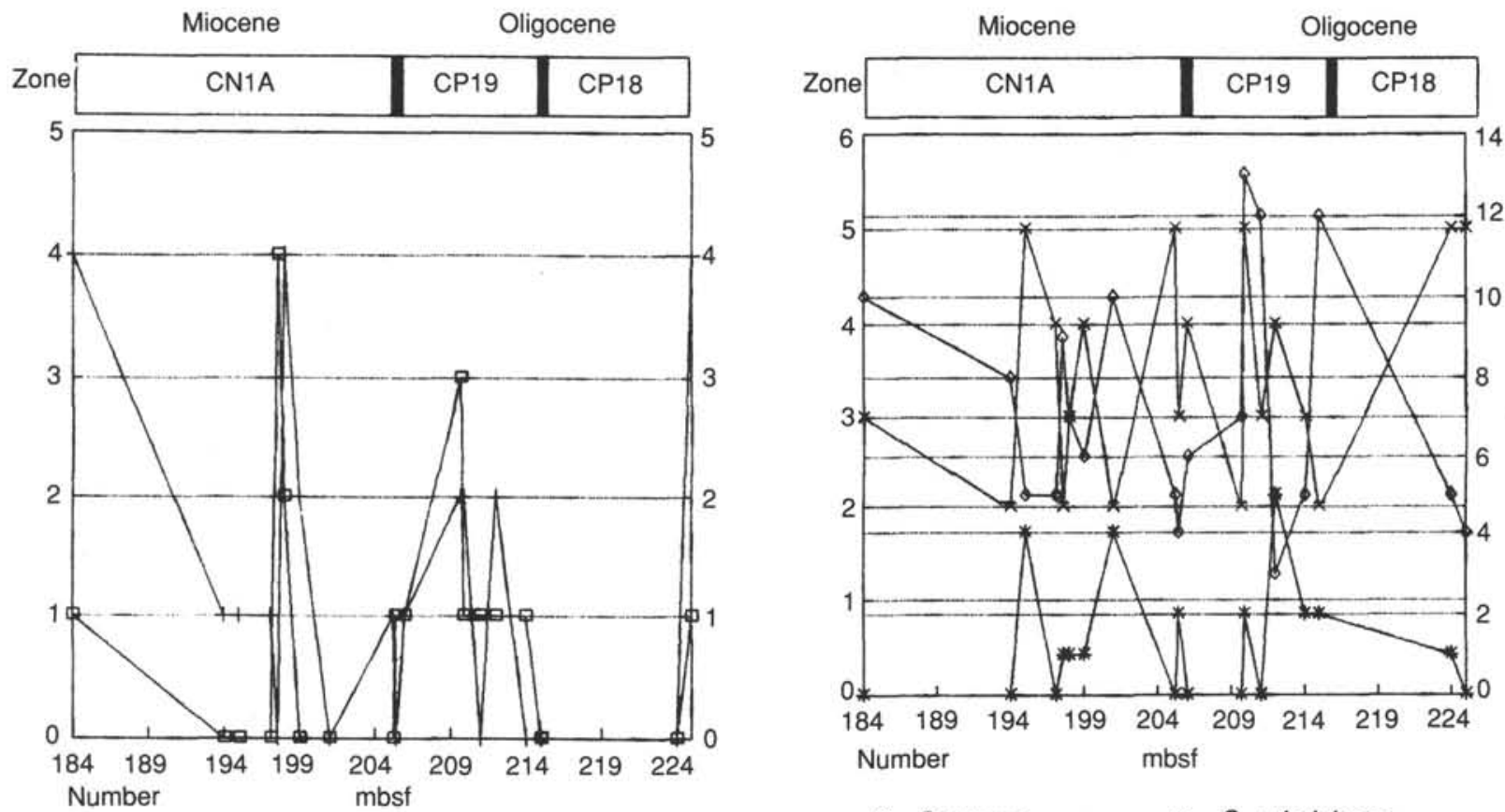

$$
+ \text { Total uvigerinids } \rightarrow \text { C. kullenbergi }
$$
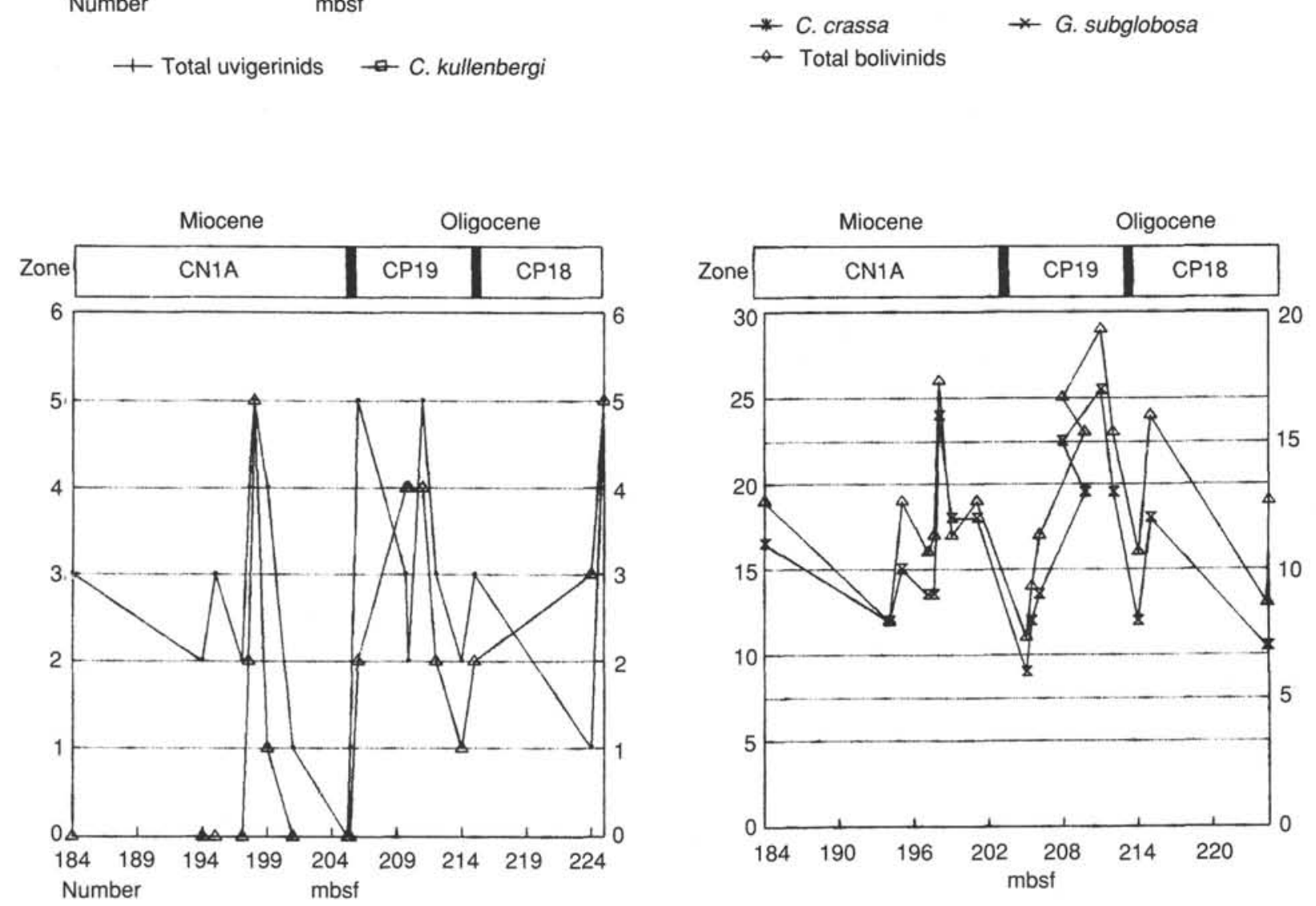

-S. lepidula $\leadsto$ O. umbonatus

$\triangle$ Diversity $\rightarrow$ Infauna

Figure 4. Relative abundance of most common benthic foraminifers from the late Oligocene into the early Miocene in Hole 714A. Species include Uvigerina spp., Cassidulina crassa, Stilostomella lepidula, Cibicidoides kullenbergi, Globocassidulina subglobosa, Oridorsalis umbonatus, and total bolivinids combined. Relative abundances of all bolivinids combined vs. total benthic diversity (species richness) vs. total abundance of infauna indicate that, with the exception of one peak, all indexes are lower in the early Miocene. Abundance of infauna is related to elevated carbon rain rates and organic carbon content of sediments (Corliss and Chen, 1988). This organic carbon serves as food for the foraminifers and may be partially responsible for supporting a greater number of benthic species. High bolivinid abundances have been attributed to the development of low-oxygen conditions. Zonation from Backman, Duncan, et al. (1988). 
ords from Zone N17 (Vincent et al., 1985). The well-known 1\% negative shift in Epoch 6 has been attributed to erosion of organic matter into the ocean and the expansion of the oxygen minimum during that portion of Zone N17 equivalent to nannofossil Zone CN9b (Vincent et al., 1985; Woodruff, 1985). In Hole 709B, this event is recorded from 92 to $98 \mathrm{~m}$ below seafloor (mbsf), dated around 6.3-6.5 Ma (Woodruff et al., this volume).

The terminal Miocene benthic oxygen isotope excursion is clearly recorded at middle latitude Site 253 where Uvigerina values become approximately $0.6 \%$ heavier at the end of Zone NN11 (Oberhänsli, 1986). This event is well recorded in the Pacific realm (Elmstrom and Kennett, 1985; Boersma, 1985c), but it is not visible in the Oridorsalis or cibicidid data from the Indian Ocean (Vincent et al., 1985; Woodruff et al., this volume). The lack of a benthic oxygen-isotope enrichment event, combined with the low abundance of Uvigerina hispidocostata usually associated with this event, suggests that there may be a hiatus in several Mascarene Basin sites through this interval.

Analysis of global benthic carbon-isotope values indicates that Atlantic deep-water masses were no longer "aged" and that the source of deep waters probably resided in the North Atlantic after $10 \mathrm{Ma}$ (Woodruff and Savin, 1989). This means that the Indian Ocean was no longer a source area of deep water to the Atlantic and Pacific oceans in Zone N17.

\section{Time Slices N18 and N21}

Although an early Pliocene glacial event has been recorded in the Pacific, the low-amplitude stable isotope fluctuations suggest less buildup of glacial ice and warmer temperatures than in the late Pliocene or Pleistocene. An $\sim 1 \%$ Pacific-Atlantic carbon isotope gradient in the early Pliocene (Shackleton et al., 1984) suggests that the Indian Ocean no longer served as a source area for Atlantic deep waters and that the predecessor of NADW was producing deep water as vigorously as it does today (Shackleton et al., 1984; Hodell et al., 1985). Global cooling combined with a benthic carbon-isotope-depletion episode characterize the N21 time slice equated roughly to the Gauss.

\section{DEVELOPMENT OF BENTHIC FAUNAS THROUGH TIME AND SPACE}

\section{Oligocene}

Oligocene biozones are not well represented at most sites, and sediments are well preserved only from the climatically warmer intervals late in Zones P19, P21a, and P22. Although the Eocene/Oligocene transition occurs in a siliceous facies in the Mascarene area, early Oligocene age faunas are rarely found in this data set from Ninetyeast Ridge, or at Sites 214 and 219. The shortness of Zone P21b, found only at deep-water Sites 217 $(3020 \mathrm{~m})$ and 709 and intermediate-depth Site 707 , suggests an extensive hiatus in this zone.

Redeposition occurs at all depths. At the deepest western basin Sites 710, 241, and 236, most levels contain material redeposited from intermediate depths rather than from shallow waters. Most of the Oligocene sediments at Site 712 are reworked, mixed, and disturbed. On Ninetyeast Ridge, an extended erosional event interrupted Zone P20, as this zone is commonly missing or contains levels with reworked Eocene fossils at several sites.

\section{Intermediate-depth Sites}

Although the CP16-CP17 (P18-P19) zonal interval was not well preserved, it was recovered at Wharton Basin Site 214 and Mascarene Basin Site 707 within the 1500-1700-m depth range. At Site 707 (Fig. 3), faunas consistently contain Osangularia mexicana, G. subglobosa (large form), Bolivina tectiformis, Ci- bicidoides havanensis, Oridorsalis umbonatus, Bulimina alazanensis, and an elongate buliminid with fine costulae. Crenulate bolivinids, such as Bolivina cf. B. pseudoplicata, occur in some numbers only in the earliest part of Zone P18 (= Zone CP16) (Table 3). Infauna fluctuate in number but are generally more numerous than epifauna. There is a clear trend to reduction in abundance of epifaunal species, such as $O$. mexicana, $C$. havanensis, and $O$. umbonatus, and a gradual increase in abundance of infaunal species, such as the bolivinids, uvigerinids, and stilostomellids.

Although more species occur consistently at Site 214, a $G$. subglobosa-C. havanensis-costulate buliminid-O. umbonatus index fauna (Fig. 5) also prevails there (Table 4). At both sites, epifaunal and infaunal diversity are equal, even though the relative abundance of infauna is greater at Site 214.

Zone P20 (= Zones CP17-CP18) age material was retrieved only at Site 707 (Fig. 3) where the poorly preserved faunas are low in diversity and dominance, redeposited material is common, a hiatus is clearly indicated, and most species occur in only one sample. Bolivinids are absent and the only consistently occurring form is the elongate costulate buliminid. Epifaunal diversity continues to equal infaunal diversity throughout this time period.

Zone P21a (= Zone CP18) age faunas were recovered to the east at Sites 714, 216, and 253, and to the west at Site 707. In the northern Central Indian Basin Site 714 (2038 mbsl), faunas rich in $O$. umbonatus and $G$. subglobosa are replaced by a $B$. tectiformis-Uvigerina spinulosa-G. subglobosa index fauna with Stilostomella lepidula (Fig. 5 and Table 5).

At the deeper Wharton Basin Site 216 (2252 mbsl), faunas contain Cibicidoides praemundulus, O. umbonatus, C. havanensis, Vulvulina spinosa, Stilostomella nuttalli, and, at the top of the interval, the abyssal form Nuttallides umbonifera and the deep-water taxon Pullenia quinqueloba (Table 6). Central Indian Basin middle-latitude Site 253 contains a different fauna, with $O$. umbonatus, Stilostomella gracillima, C. havanensis, Gyroidinoides altispirus, reticulate $C$. havanensis, and uvigerinids, including the usually deeper water form, Uvigerina spinicostata (Table 7). Infaunal diversity and abundance are consistently greater except at Site 216 , in which epifaunal abundance is equal to or greater than infaunal abundance (Fig. 5).

By Zone P21a at Site 707, although siliceous fossils predominate, benthic species $C$. praemundulus, B. tectiformis, Bolivinopsis gryzbowski, G. subglobosa (small form), and the uvigerinids become more abundant than rotaloid species (Fig. 3). Buliminids include both the reticulate Bulimina semicostata and the finely porous Bulimina macilenta.

Faunas of Zone CP19 (Zone P21b) age could be definitely identified only at Site 707 . With the loss of $O$. mexicana, B. tectiformis predominates (Table 3 ), accompanied by $S$. gracillima and Siphonodosaria modesta. Uvigerina spinicostata is occasionally present. Diversity reaches a maximum at this time and dominance is low.

Faunas of Zone CP19 (Zone P22) age were recovered at Sites 714,217 , and 253 to the east and Site 707 to the west. This is the most consistently recovered zone of the Oligocene, especially in deeper sites. Beginning in Zone CP19, faunas develop remarkable similarity; an S. gracillima-O. umbonatus index fauna proliferates with depth in the Mascarene Basin and to the east and west of Ninetyeast Ridge (Fig. 6).

Different species characterize the early and later part of Zone P22. For example, at Site 253 Uvigerina spinicostata and $N$. umbonifera, which occur in early Zone P22, are replaced by $E$. exiguua and $U$. spinulosa at the end of this interval (Table 7). At Site 714 , U. spinulosa, Planulina renzi, Cassidulina crassa, and osangularids occur at the beginning of the zone but are largely absent by its end when $P$. quinqueloba first occurs (Table 5). 
Site 714 offshore southern India on the Chagos-Laccadive Ridge stands out in contrast to all other sites because large numbers of bolivinids occur the most consistently of all species. Intrageneric diversity is highest in this genus, and species richness is highest at this site. Bolivinid abundance is episodic at the beginning of this zone but is consistent toward its end (Sections 115-714A-23X-6 to 115-714B-23X-1) (Table 5). Crenulate types with large pores replace the reticulate group and $B$. tectiformis in abundance in Zone CP19, but there is a diversity maximum and an acme of smoother, thinner forms with smaller pores in 115-714B-23X-6 (Fig. 7). Bolivinids and $C$. crassa, which vary directly but inversely with $G$. subglobosa, reach abundance maxima in this interval (Fig. 4). Oridorsalis umbonatus and $S$. lepidula vary synchronously and directly, reaching maxima later in this zone. The Neogene forms, $C$. kullenbergi and $O$. culter, which appear to occur here earlier than at other locations, alternate with an O.umbonatus-S. lepidula index fauna in which $G$. subglobosa is abundant (Fig. 5).

Faunas at Site 216 are characterized by large faunal turnover, with 12 species disappearing near the top of the Oligocene, including the costulate buliminid, Pullenia quinqueloba, N. umbonifera, $S$. nuttalli, $V$. spinosa, and the bolivinids (Table 6). The $S$. lepidula-O. umbonatus index fauna here includes also Gyroidinoides planulatus, $G$. subglobosa (large form), fewer $C$. praemundulus, and $U$. spinicostata (Fig. 5).

At Site 253 to the south in the middle latitudes, a similar fauna consistently contains $B$. semicostata, fewer $C$. havanensis than previously, $O$. mexicana, $P$. quinqueloba, increased numbers of bolivinids and buliminids, and N. umbonifera followed by Uvigerina spinulosa near the end of the zone (Table 7). Infaunal species outnumber epifaunal species 4 to 3 in the youngest levels, but infauna are almost two times more abundant than epifauna. A similar $S$. gracillima-O. umbonatus index fauna with $B$. semicostata and a uvigerinid-rich level near the end of Zone P22 occurs also at Site 707 to the west (Fig. 5). Uvigerinid diversity is greatest here of all sites, involving the species $U . s p i-$ nulosa, Uvigerina havanensis, Uvigerina subproboscidea, and the New Zealand form, Uvigerina ongleyi. Uvigerinids are particularly abundant at the end of this time when infaunal diversity exceeds epifaunal diversity by 7 to 1 , and infauna are three times more abundant than epifauna (Table 3).

\section{Deep-water Sites}

Oligocene deep-water faunas were recovered at few deep sites: Sites 217 and 712 to the east, and Sites 238 and 709 to the west. Abyssal faunas were counted only from the Mascarene Basin at Site 710 . In the deepest sites, redeposition and dissolution are extreme even at depths close to $3000 \mathrm{~m}$. Faunas are dominated by generalists, but include such deep-water forms as Heterolepa grimsdalei, P. quinqueloba, $S$. nuttalli, and to a lesser degree, $N$. umbonifera. Either through dissolution, redeposition, or ecology, bottom-water faunas close to $3800 \mathrm{mbsl}$ differ from their southern Atlantic analogs (Tjalsma, 1983; Clarke and Wright, 1984; Boersma, 1985a) in their scarcity of $N$. umbonifera.

The early Oligocene interval was not often recovered in deep or abyssal sites. Relatively well-preserved faunas of Zone CP16 (= Zone P19) recovered only at Site 217 in the Bay of Bengal contain $O$. umbonatus, C. praemundulus, G. altispirus, $H$. grimsdalei, $U$. havanensis, and, in one level, N. umbonifera (Table 8). Faunas of Zones CP17-CP18 (Zone P20) at deep-water Site 709 are characterized by poor preservation, but greater diversity and low dominance (Fig. 8). Typical are $S$. gracillima, G. subglobosa (small form), and in one level, N. umbonifera.

Late Oligocene faunas of Zone CP18 (Zone P21a) age, retrieved at all sites, are characterized by improved preservation, especially at abyssal depths along the Mascarene traverse. At the deepest Site 710, G. subglobosa (large form), O. umbonatus, and $C$. praemundulus occur at more than one level, and a slight increase in N. umbonifera occurs in Sample 115-710C-20X-CC (Table 9). At deep-water Site 709, despite the poor preservation, diversity is at a maximum lower in the zone, whereas dominance remains low (Fig. 8). Faunas consistently contain C. praemundulus, $S$. gracillima, and $G$. subglobosa (small form), with one sample enriched in $N$. umbonifera. Stratigraphic resolution is not fine enough, however, to determine whether this $N$. umbonifera enrichment event is coeval with that at abyssal Site 710 (Fig. 5).

Samples from Site $217(3020 \mathrm{~m})$ to the east in the Bay of Bengal contain high-diversity faunas with common $G$. subglobosa (large and small), O. umbonatus, $C$. praemundulus, and $S$. nuttalli (Table 8). Both $N$. umbonifera and the costulate bolivinids are present, but in low numbers (Fig. 5).

At Site $238(2826 \mathrm{~m})$ in the Central Indian Basin, preservation is poor and fossil abundance low (Table 10). One diverse fauna contains $S$. nuttalli, $S$. gracillima, $O$. umbonatus, and $B$. semicostata. Deep-water faunas of both the northern Mascarene and Central Indian basins are similar to the $O$. umbonatus-S. gracillima index faunas found at nearby intermediate-depth sites (Fig. 5). It is not certain, therefore, whether intermediate-water fossils have moved downslope via migration or redeposition.

A short interval of Zone CP19 (Zone P21b) was recovered in the 3,000 m depth range at Site 709 to the west and at Bay of Bengal Site 217 to the east. At Site 709 (Fig. 8), preservation improves and the fauna is somewhat diverse, containing the maximum of $C$. praemundulus, consistent $O$. umbonatus, $G$. subglobosa (small form), S. nuttalli, B. tectiformis, and U. spinicostata. The only truly deep-water heavily calcified bolivinid, called Bolivina huneri (Tjalsma and Lohmann, 1983), occurs at this site (Table 11). The dissolved faunas at Site 217 are very small, the only consistent species being $O$. umbonatus and $P$. quinqueloba (Table 8).

Faunas of Zone CP19 (= Zone P22) were recovered at all sites, although the samples from Site 710 were minute and badly dissolved (Table 9). Present at this site was a new dissolution residue consisting of $O$. umbonatus, G. planulatus, and $P$. bulloides. Gyroidinids increase in abundance in the top samples of this zone. At deep-water Site 709 (Fig. 8), O. umbonatus, G. girardanus, G. subglobosa (small form), and Anomalinoides semicribratus accompany reticulate cassidulinids in small, very dissolved samples. It is difficult to know if this fauna is in place.

At Site 238 (2826 mbsl) in the western Central Indian Basin, Zone P22 (Zone CP19) is almost 10 cores long but only fairly well to poorly preserved. Nuttallides umbonifera is more common here than at all other sites (Table 10). Present are $S$. modesta, S. gracillima, an increased number of $G$. subglobosa, pleurostomellids, and some $S$. subspinosa. A short bolivinidrich level may be the result of redeposition. At the end of the Oligocene, $N$. umbonifera, $P$. quinqueloba, C. praemundulus, and $E$. exiguua either increase in numbers or first appear (Fig. 6). A clear faunal succession can be recognized. A low-dominance, low-diversity, large $G$. subglobosa-O. umbonatus index fauna is replaced by an $S$. gracillima-O. umbonatus-pleurostomellid index fauna, then a second low-diversity, low-dominance $O$. umbonatus $-S$. gracillima index fauna, followed by the arrival of more common $N$. umbonifera, E. exiguua, or $P$. quinqueloba in the top four samples of the zone.

To the north in the Bay of Bengal in Hole 217A, the B. tectiformis-S. lepidula-G. subglobosa index fauna resembles those from Central Indian Basin Site 238, located at equivalent water depths (Fig. 6). Noteworthy is the proliferation of the costulate bolivinid, B. tectiformis, at these deep-water sites. The occurrence of the bolivinids and Cibicides laurisae, usually an intermediate-depth form, may indicate redeposition through this interval (Table 8). If these bolivinids are not redeposited, then 
Table 3. Ranges of benthic foraminifers from the late Eocene through the Oligocene in Hole 707A.

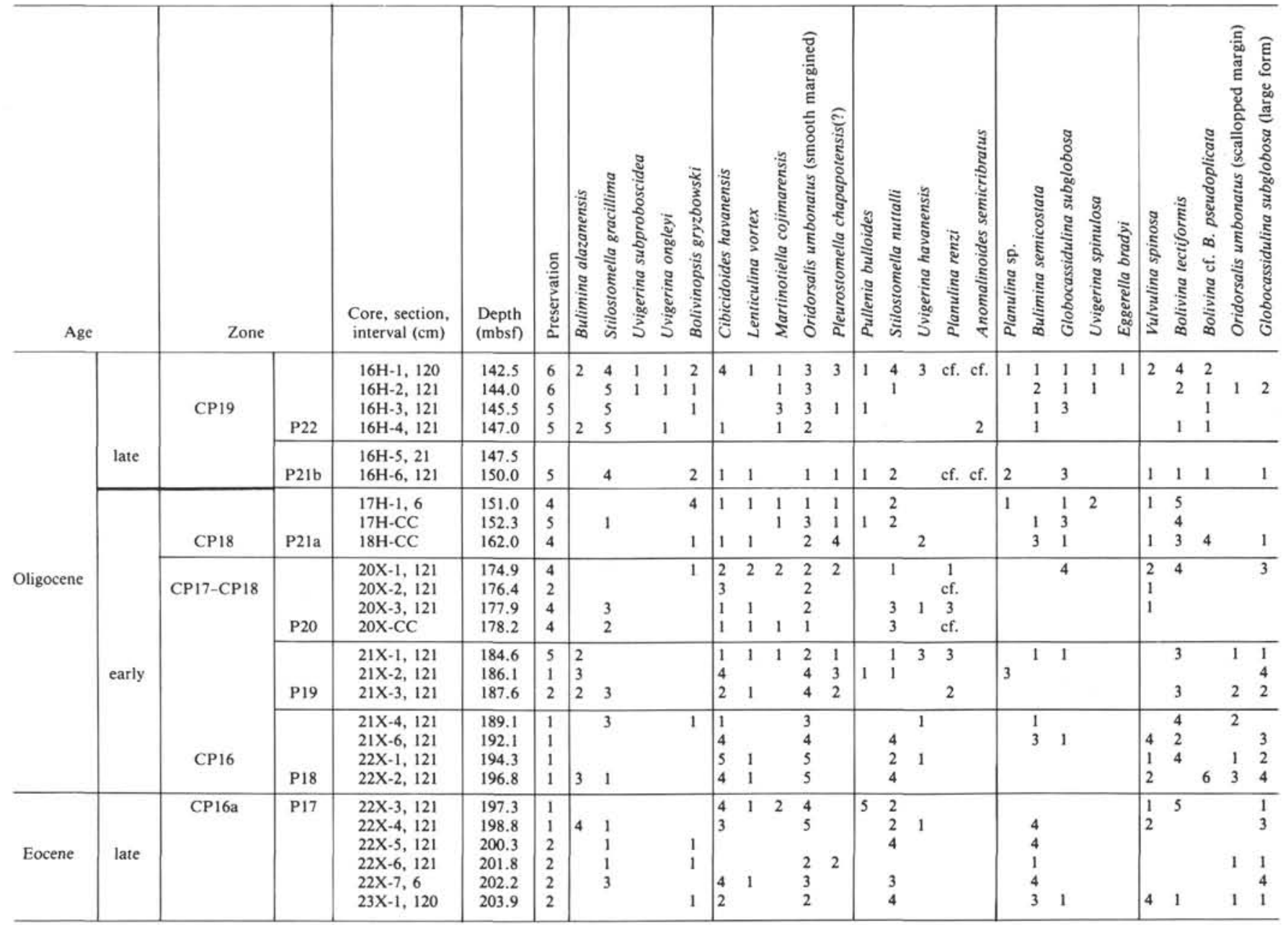

Notes: Preservation was assessed according to the following scheme: 1 , very very poor; 2 , very poor; 3 , poor; 4 , fair; 5 , good; 6 , very good; 7 , excellent. Number of infauna, epifauna, total species diversity, and abundance of infaunal vs. epifaunal species for each sample are tabulated to the right. Biozonation is based on nannofossils, but planktonic foraminifer zones are also shown (Backman, Duncan, et al., 1988)

their occurrence at Site 217 suggests that the bolivinid-rich level at Site 238 is also in place and that the lower depth limit of intermediate-depth faunas has been depressed to $2800 \mathrm{mbsl}$.

\section{Neogene Deep-water and Intermediate-depth Sites}

\section{Miocene}

All basinal samples from Sites 251 (3498 m), 236 (5140 mbsl), and $241(4054 \mathrm{~m})$ contain material redeposited from intermediate depths. At Site 236 in the Mascarene Basin, an abundance of crenulate bolivinids suggests a more northerly origin for the sediments, as these bolivinid-rich faunas do not occur at intermediate depths on the Mascarene Plateau, but farther north at sites on the Chagos-Laccadive Ridge.

Faunas of early Miocene Zones CN1-CN3 (= Zones N4N7) were recovered both along the Mascarene depth traverse and to the northeast at Sites 714 and 715. Preservation is fair except at Site 710, where it is generally poor as a result of extreme dissolution. Benthic foraminifers are less numerous than previously at all sites, fewer species dominate the samples, and many species are small in size. Benthic foraminifers are least common and diversity is lowest at intermediate-depth Site 707. Even at Site 714 , in which diversity is greater, the number of specimens per $\mathrm{mg} /$ sediment is low.
This interval is unique because of the similarity of faunas along the Mascarene depth traverse. Cibicidoides kullenbergi, $O$. umbonatus, G. subglobosa, S. lepidula, and S. nuttalli are found at all depths (Fig. 9). Nuttallides umbonifera occurs in the deeper two sites, 709 and 710 (Tables 9 and 11), and migrates updepth to Site 707 during one short episode midway through the zone (Table 12). Mixed tan and grey sediments at Sites 707 and 709 give evidence of oxidation or sediment mixing by burrowing organisms through this interval. Oxidation may be primary or may have occurred during episodes of sediment mixing or redeposition.

As in the Oligocene, the earliest Miocene age faunas at Central Indian Basin Sites 714 and 715 are entirely different from those along the Mascarene traverse. Bolivinids are the most common forms at both sites, but the crenulate bolivinids with large pores, such as B. pseudoplicata, predominate (Fig. 7). Although pleurostomellids are more common in the small faunas at Site 714 (Table 5), Bolivinita quadrilatera, G. subglobosa, and the flat, costulate bolivinid Bolivina striatocola characterize the higher diversity faunas at the slightly deeper Site 715 (Table 13). Dominance and benthic abundance are greater at Site 715 .

Middle Miocene Zone CN4 (= Zone N9) age faunas were identified only at the intermediate sites. At Site 707, the only forms present were large and small G. subglobosa, O. umbonatus, and $O$. bengalensis. Bolivinids were absent (Table 12). 
Table 3 (continued).

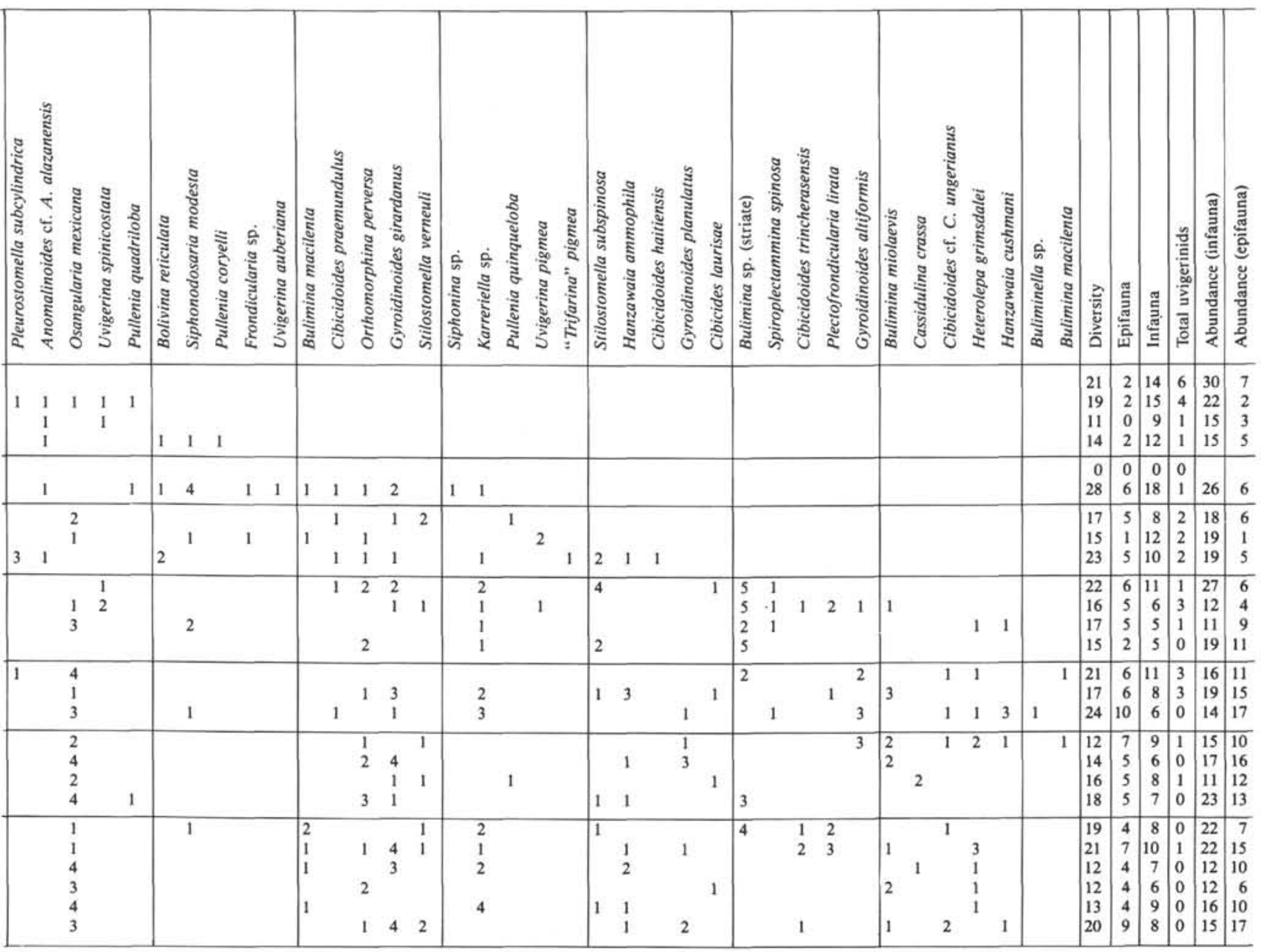

A different faunal stratification characterizes Sites 714 and 715 at this time (Fig. 10). Faunas at Site 714 become dominated by smoother, flatter, finely porous bolivinids such as Bolivina pukeuriensis, Bolivinita, several crenulate bolivinids, S. lepidula, and G. subglobosa (Table 14). Richer faunas at Site 715 are dominated by $U$. auberiana, C. kullenbergi, $C$. wuellerstorfi, $E$. hystrix, G. subglobosa, and increased numbers of cibicidids, but the bolivinids are virtually gone. Pullenia quinqueloba occurs in only one interval (Table 13). Clearly, different conditions developed between Site 714 at $2038 \mathrm{mbsl}$ and Site 715, located at 2262 mbsl.

Late Miocene Zone CN9 ( = Zone N17) was recovered at all three sites along the Mascarene traverse and to the east at Central Indian Basin Site 713 and Arabian Sea Site 219, but was represented by a hiatus at the northeastern Chagos-Laccadive Sites 714 and 715 . Most samples are characterized by high benthic foraminifer diversity and improved carbonate preservation. Along the Mascarene depth traverse (Fig. 11), uvigerinids, miliolids, and lagenids increase through this time. At intermediatedepth Site 707, very well-preserved $U$. auberiana, small $G$. subglobosa, lagenids and $C$. wuellerstorfi predominate (Table 12). In Zone CN9b (Zone N17b), an index fauna containing uvigerinids, Rectuvigerina spinea, and E. exiguua characterizes the end of the Miocene (Fig. 11).

At deep-water Site 709, both small- and large-sized $G$. subglobosa predominate along with $O$. umbonatus, $U$. proboscidea, N. umbonifera and fluctuating numbers of uvigerinids (Table
15). Present also are several large species first named in Car Nicobar, for example, Nodosaria skobina and Chrysalogonium setosum, together with the intermediate-water uvigerinid $R$. spinea (Boersma, 1984, 1985c). Because sediments throughout this interval are white and oxidized tan, some specimens are unusually large, and uvigerinid species usually restricted to intermediate depths are present, it is again unclear whether the sediments at Site 709 are in place. Redeposition or burrowing activity is suggested by the mottled sediments. The interval closes with an increase in the numbers of uvigerinids and Pyrgo spp. (Fig. 11).

At abyssal Site 710 (Table 16), preservation improves, diversity increases, and $E$. exiguua, N. umbonifera, and $O$. umbonatus occur in some number along with $C$. wuellerstorfi.

To the east, in the Central Indian Basin at deep-water Site 713 , the dominant species are the crenulate bolivinids, lagenids, $G$. subglobosa, B. alazanensis, $O$. umbonatus, $U$. auberiana, $C$. kullenbergi, and Favocassidulina fava (Table 17). Diversity is high (27-30 species), and dominance is high. It is possible that intermediate-water faunas represented by the crenulate bolivinids are mixed into deep-water faunas at Site 713. Near the end of this time, $N$. umbonifera appears, together with increased numbers of uvigerinids, Pyrgo murrhina, and $F$. fava, the loss of all crenulate bolivinids, and faunal overturn involving the loss of 11 species (Fig. 11).

To the north in the Arabian Sea, at intermediate-depth Site 219 , diversity reaches its Neogene maximum for all sites (46 species). These rich, moderately well-preserved faunas are domi- 


\section{A. BOERSMA}

Mascarene Basin

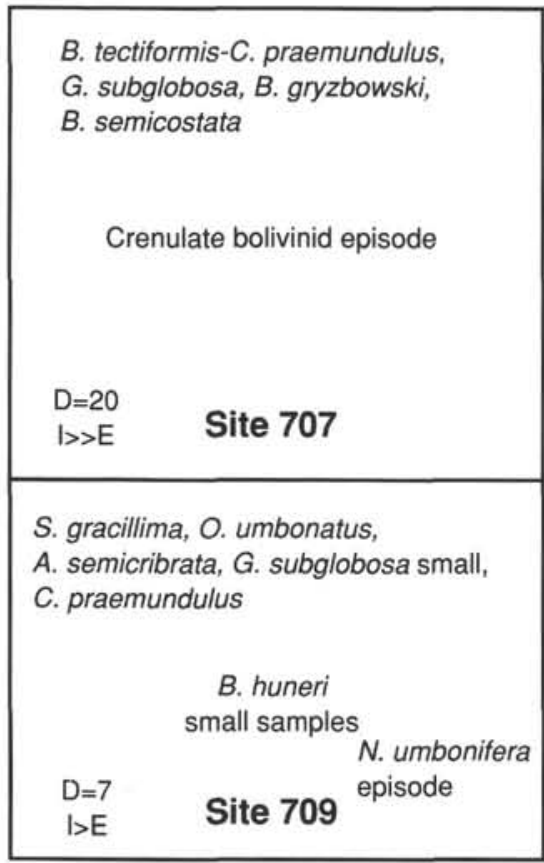

Wharton Basin

C. praemundulus, $O$. umbonatus,

G. subglobosa, G. girardana

Buliminella, buliminids

$\mathrm{D}=17$

$E=0 r>1$

Site 216

O. umbonatus, C. praemundulus,

G. subglobosa large

E>I

Site 710
Proto-

AAIW

Oxic

Widw

Few benthics

Low diversity
Central Indian Basin

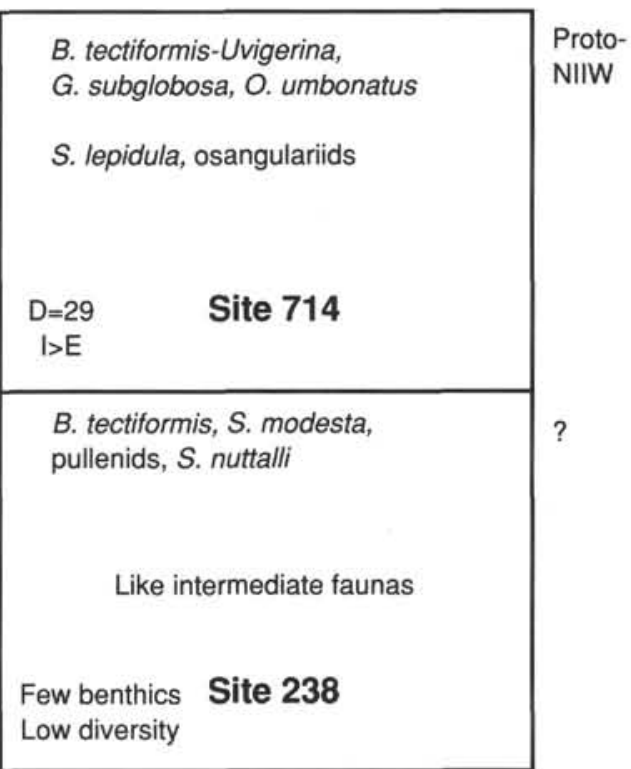

Less oxic NEiw

Oxic

Widw \begin{tabular}{l|l} 
O. umbonatus, G. altispira, & Fertile \\
C. havanensis, S. gracillima & proto- \\
& AAIW
\end{tabular}

U. spinicostata

B. miolaevis

$\mathrm{D}=27$

$1>E$
Time slice

P21

Mascarene Basin

Figure 5. Benthic foraminifer index faunas of late Oligocene Zone P21 (= Zone CP18) from seven sites in the western and central Indian Ocean. Indexes, listed at top, were most abundant or most consistently present. Index forms that occurred only in pulses or discrete episodes are shown below. Total sample diversity and the relation of infaunal to epifaunal abundance are shown at bottom left of each box. The faunal name assigned to each index fauna is listed to the right of each box. Data from Tables 3-11. 
Table 4. Ranges of benthic foraminifers from the early Oligocene to the early Miocene at Site 214 .
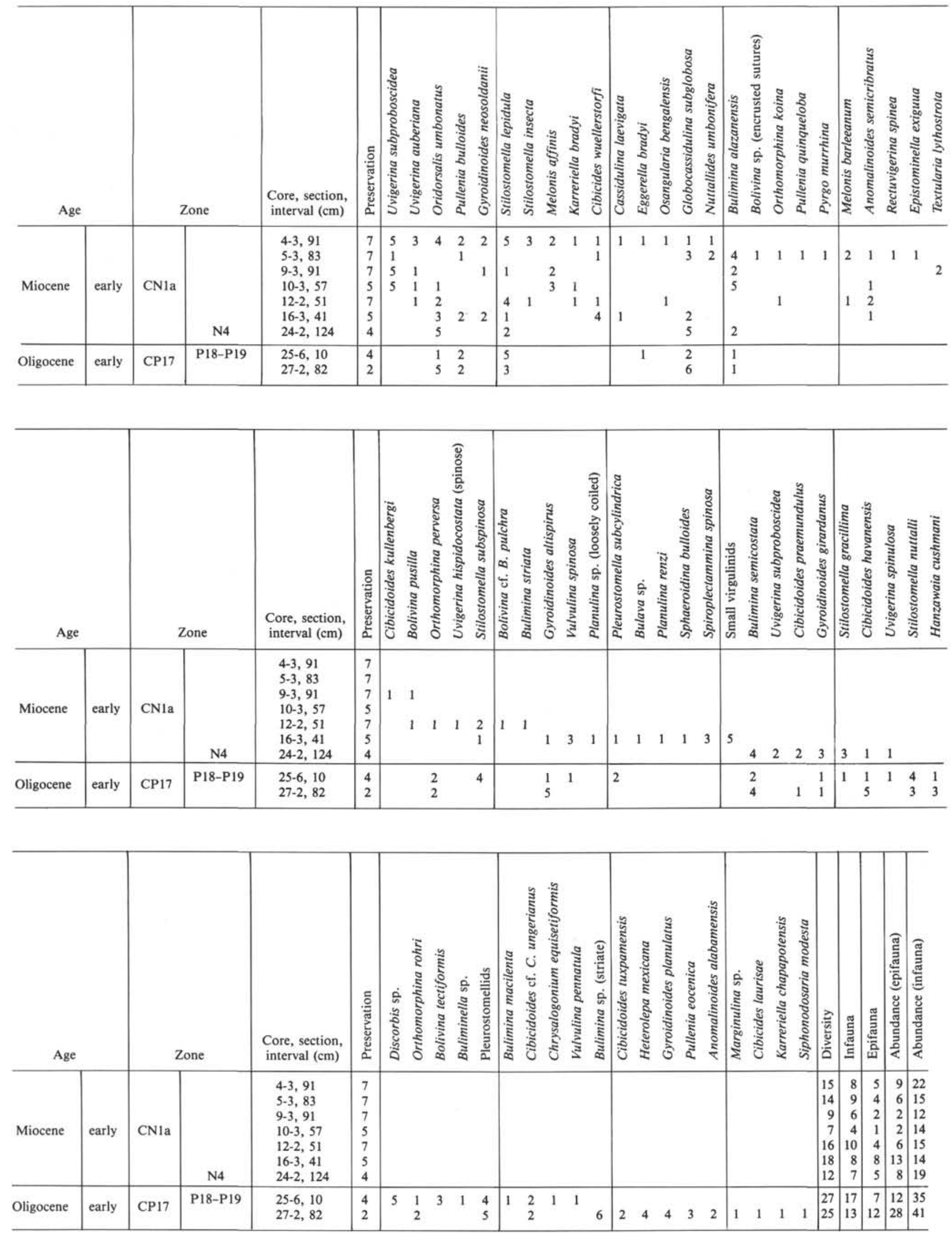

Note: Explanation as in Table 3. 
Table 5. Ranges of benthic foraminifers from the late Oligocene to the early Miocene in Hole 714A.

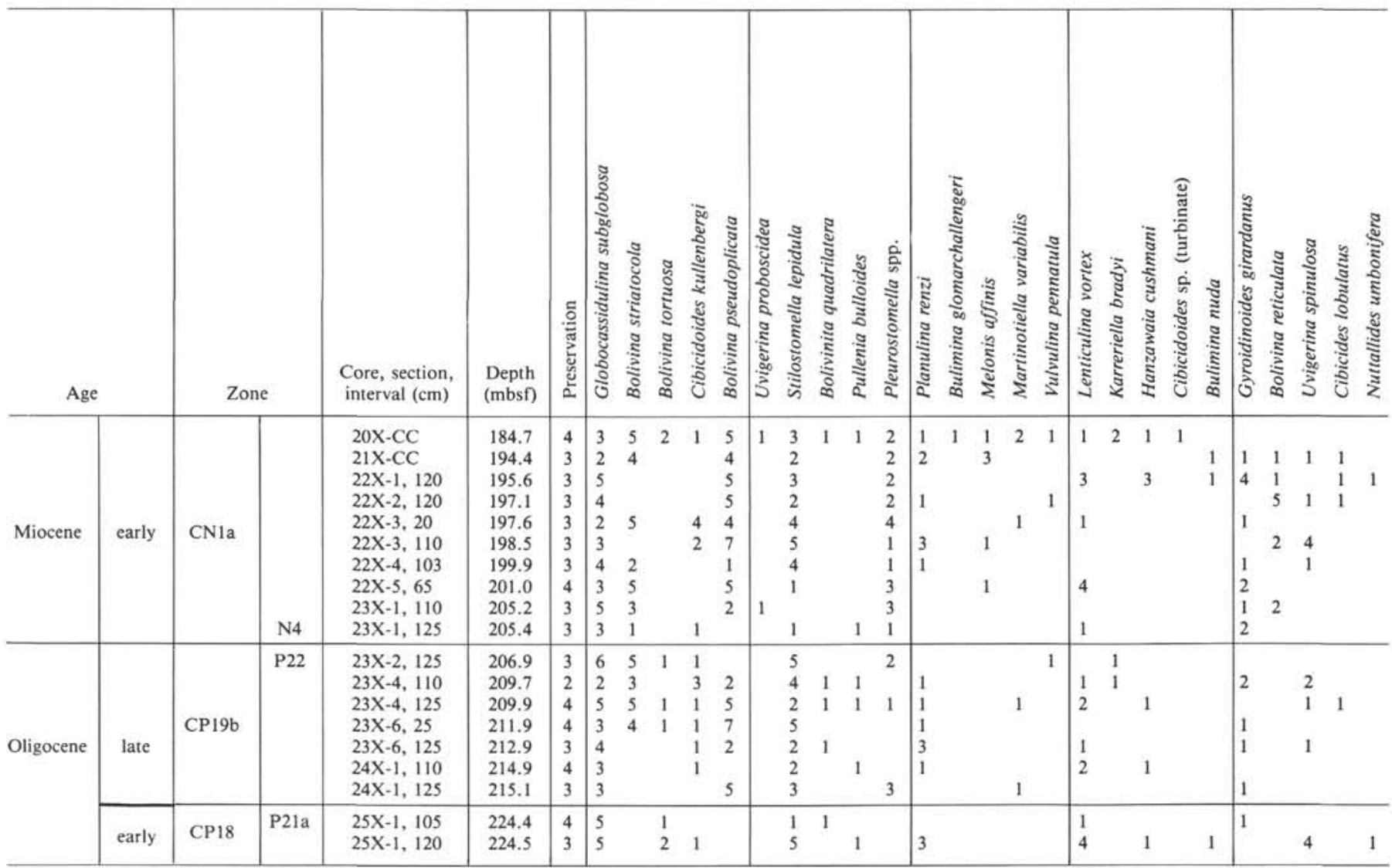

Note: Explanation as in Table 3.

nated by Uvigerina proboscidea, B. alazanensis, O. umbonatus, G. subglobosa, S. lepidula, Rectuvigerina multicostata (Table 18 ), and the smooth, lenticular bolivinid with large pores, $B$. pulchra. Epistominella exiguua occurs for the first time in this zone, and $O$. bengalensis disappears. The end is characterized by the only appearance of $N$. umbonifera and the replacement of the large-pored and crenulate bolivinids by the smooth, flat costulate types, together with increased numbers of uvigerinids and faunal overturn involving the loss of 7 species, including Hoeglundina elegans and Ehrenbergina trigona (Fig. 11).

\section{Pliocene}

Early Pliocene zonal interval CN10-CN11 (= Zones N18N19) faunas were identified at all three sites along the Mascarene traverse, as well as at Site 238 in the Central Indian Basin. At the shallowest Site 707, benthic foraminifers become scarcer and remain so throughout the remainder of the Cenozoic. Lagenids, G. subglobosa, O. umbonatus, and Melonis pacificum occur consistently, while crenulate bolivinids occur episodically (Table 19). The finely hispid uvigerinids vary inversely with $G$. subglobosa throughout this interval, with the uvigerinids more numerous when diversity and numbers of infauna are also greater (Fig. 12).

Miliolids, all size classes of G. subglobosa, lagenids, O. umbonatus, $F$. fava, and $G$. neosoldanii are typical at deeper Site 709 (Table 20), along with several large forms attributable to the Car Nicobar fauna (Fig. 13). It is again not clear how much of this fauna is in place. In general, the finely hispid uvigerinids and $G$. subglobosa vary inversely at this site, while the abundance of $N$. umbonifera varies directly with that of the epifauna
(Fig. 14). Diversity and the numbers of infauna and epifauna all decrease through this time.

Despite improved preservation, abyssal faunas at Site 710 remain small, but they do include a new group of solution-resistant forms including Melonis pompilioides, $G$. neosoldanii, $P$. quinqueloba, and $O$. umbonatus (Table 16). Redeposited fossils still occur in this abyssal fauna.

At Arabian Sea Site 219, intermediate depths are characterized by high-diversity faunas similar to those of the late Miocene, but are typified by such flat, smooth, costulate bolivinids as B. pusilla and by miliolids. In Zone N18, an abundance pulse of $E$. exiguua and $P$. quinqueloba accompanies increased numbers of Rectuvigerina multicostata and the lenticular, large-pored bolivinid, B. pulchra (Fig. 14).

Deep-water Central Indian Basin Site 238 faunas are characterized by $G$. subglobosa (small form), M. pompilioides, $F$. fava, a triangular-shaped uvigerinid related to Uvigerina pigmea (tentatively called "Trifarina" pigmea here), miliolids, turbinate cibicidids, $P$. bulloides, and $C$. wuellerstorfi (Table 10). Such Car Nicobar species as N. skobina and S. setosum are not present at this site, thus differentiating it from Site 709 located to the west at almost identical depths (Table 15).

A new $U$. auberiana- $F$. fava index fauna with high numbers of $G$. subglobosa develops at nearby Site 713. An abundance pulse of $N$. umbonifera at this site may correspond with pulses of N. umbonifera, uvigerinids, and miliolids registered at all other sites early in Zone N18 (Fig. 15).

Late Pliocene Zone CN12 (= Zone N21) along the Mascarene depth traverse is characterized by short sections and similar faunas at the two deeper Sites 709 and 710 . Site 709 contains a 
Table 5 (continued),

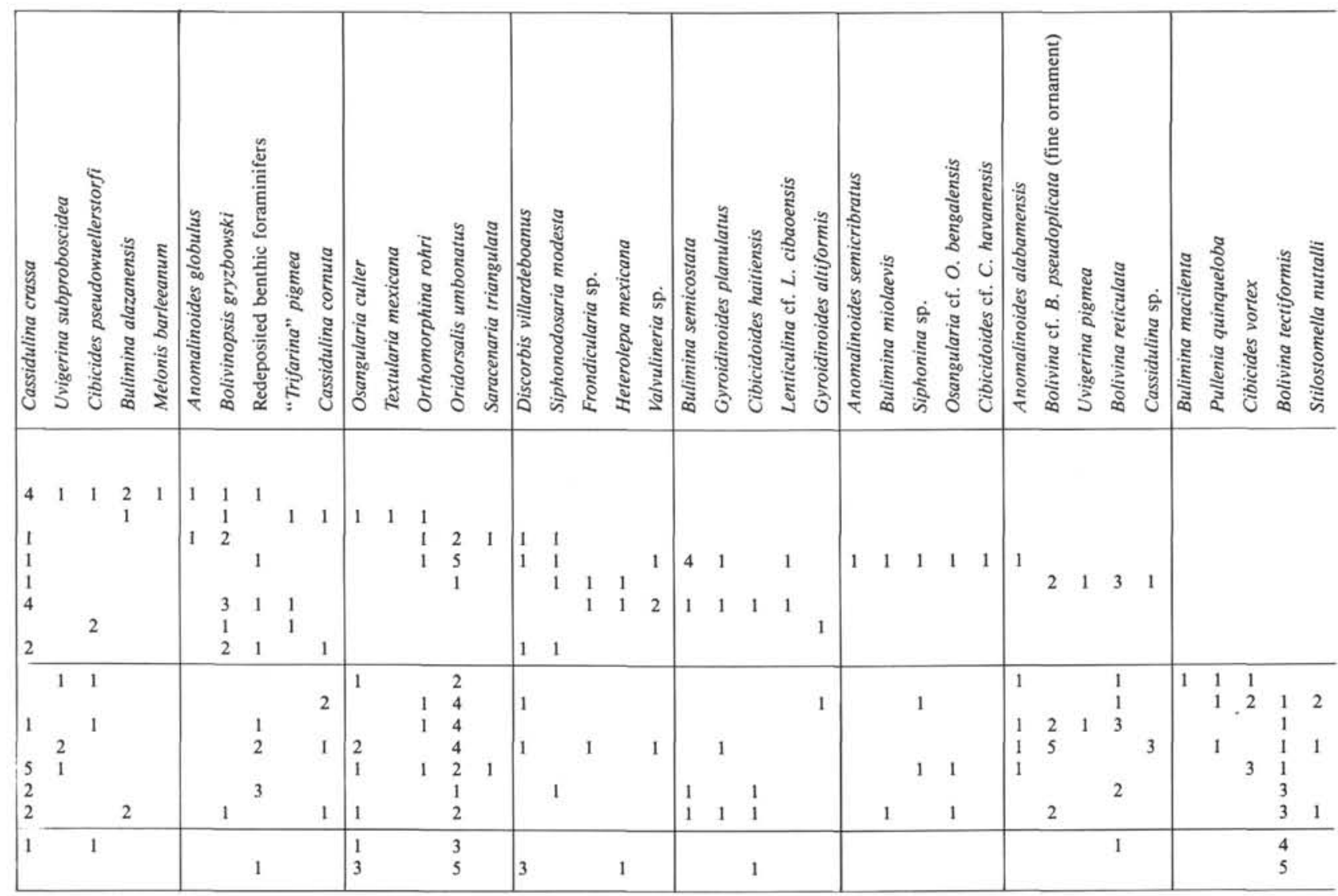

cibicidid-Pyrgo index fauna, including also F. fava, G. subglobosa, O. umbonatus, N. umbonifera and G. soldanii (Fig. 16). At Site 710 , lagenids and $M$. pompilioides are also typical. For the first time, epifaunal numbers become equal to or greater than infaunal numbers in abyssal and deep-water sites (Table 16).

Uvigerinids and bolivinids are more common at intermediate-depth sites. Both uvigerinids and cibicidids increase in number at the shallower Site 707 where crenulate bolivinids occur episodically for the last time (Fig. 16). By the end of the zone, infaunal numbers begin to drop toward values more typical of modern faunas. Farther north in the Arabian Sea at Site 219, uvigerinids predominate along with the smooth, costulate bolivinid $B$. pusilla, S. marginata, and small numbers of Epistominella exiguua and $P$. quinqueloba.

\section{DISCUSSION}

Subsurface water masses of the western Indian Ocean are produced from several source regions. Deep and bottom waters are derived from the Atlantic Ocean, as there is no evidence for formation of bottom water along the portion of the Antarctic continent south of the Indian Ocean. Intermediate waters, however, have two sources. Because of the landlocked character of the northern Indian Ocean and the lack of a connection to cool higher latitude seas, advection is slow and surface waters tend to evaporate, become highly saline, and sink to intermediate depths. Because of the fertility and high primary productivity of the northern Indian Ocean, there is such a high demand for oxygen in the water column that intermediate waters also tend to be low in oxygen. The lowest oxygen intermediate waters are currently found in the Bay of Bengal and the Andaman and Arabian seas. Intermediate water of Antarctic origin can be traced by its salin- ity minimum as far north as $10^{\circ} \mathrm{S}$. Because this water is formed by intense mixing and sinking of Antarctic surface water along the Polar Front, it is oxygen rich and low in nutrients (Wyrtki, 1973; Warren, 1981).

Modern intermediate-depth benthic foraminifer faunas in the northern Mascarene Basin, the southern Indian upwelling zone, and the southern Arabian Sea reflect these two different intermediate-depth water masses. At Site 219 in the southern Arabian Sea and Site 714 in the southern Indian upwelling zone underlying high-fertility surface waters, benthic foraminifer faunas are high in diversity and rich in infauna; the number of specimens per mg/sediment is high; and large numbers of spinose uvigerinids, stilostomellids, buliminids, and diverse bolivinids are found. In contrast, modern intermediate-depth faunas in the area of Site 707 underlying AAIW contain few specimens and few species per genus per $\mathrm{mg} /$ sediment, and no uvigerinids or bolivinids. Epifauna are more numerous in these samples and diversity is low. Such a faunal contrast should be useful for interpreting the development and geography of lowoxygen conditions from ancient sediments and faunas in the northern Indian Ocean.

Foraminifer tracers depict relative oxygenation at intermediate depths. Because low-oxygen levels develop in fertile areas where high primary production results in high organic carbon flux to the bottom, sediments underlying low-oxygen intermediate waters are often organic-carbon rich (Banse, 1968). Indexes for elevated levels of organic carbon in the sediment include species of the infaunal genera Uvigerina, Hopkinsina, and Rectuvigerina, the abundances of which correlate with high phosphate concentrations in the sediments under modern upwelling zones (Lutze, 1977; Douglas, 1981; Miller and Lohmann, 1982; Lutze and Coulbourn, 1984; Corliss and Chen, 1988). 
Table 5 (continued).

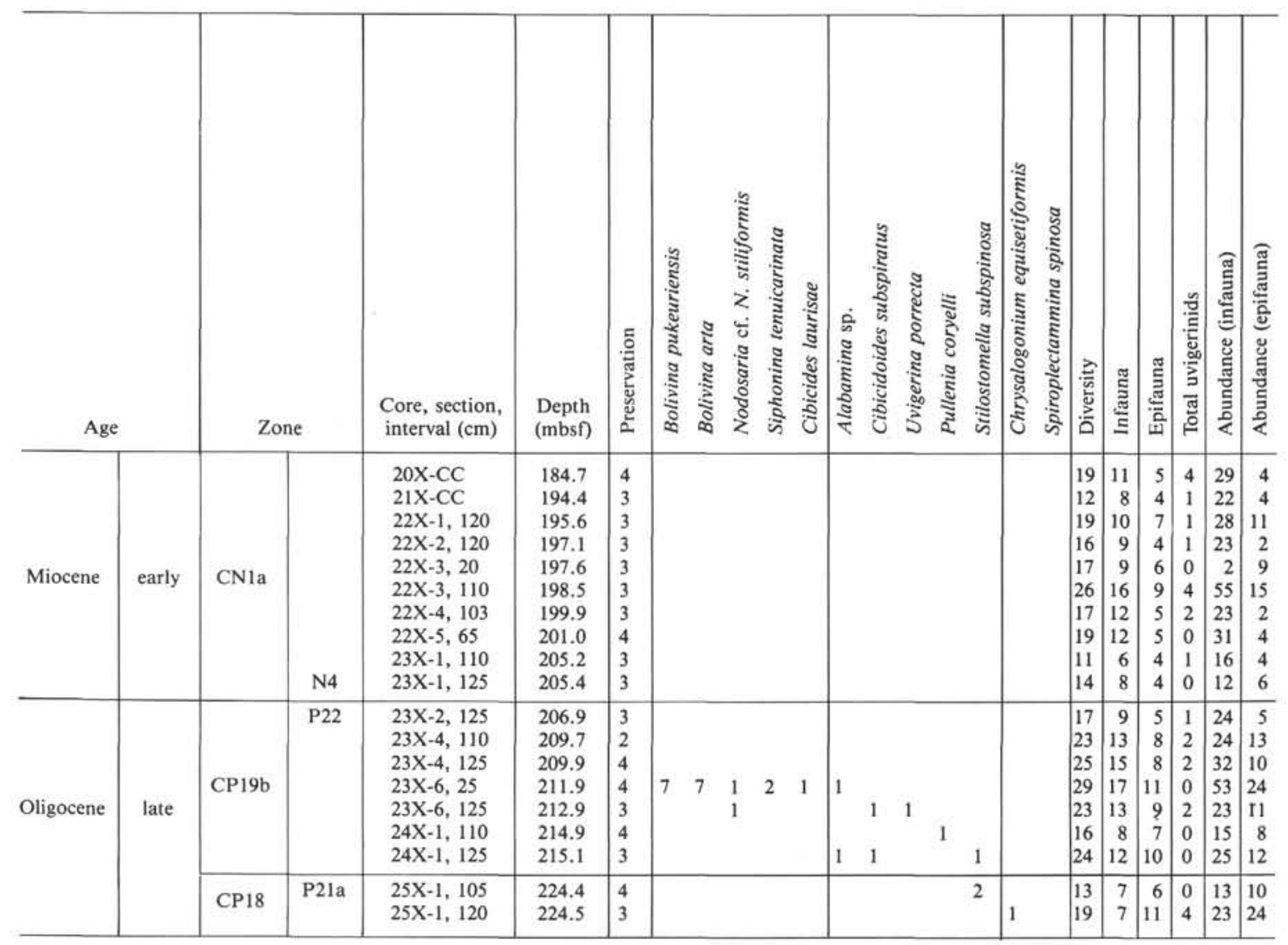

Globobuliminids and buliminids are factor-genera associated with low oxygen in the water column overlying areas with lower organic carbon in the surface sediment. In these areas, Uvigerina is the factor-genus correlated with organic carbon and silt maxima in sediments (Miller and Lohmann, 1983). Ehrenbergina, Bulimina, cassidulinids, Eponides, Laticarinina, porous melonids, miliolids, and $C$. wuellerstorfi have all been related to productivity and organic carbon accumulation in various oceanic settings (Douglas, 1981; Poag, 1981; Woodruff and Savin, 1989).

Infaunal abundance has been related to high organic carbon flux and organic carbon content in sediments in the modern North Sea. It is assumed that such sediments will also be less aerated (Corliss and Chen, 1988). Because of the complex processes determining pore-water oxygenation, however, only the association of infauna with higher organic carbon and organic carbon flux is assumed in this paper.

The relation between bolivinids and lowered oxygen levels in silled basins is well known (Hendrix, 1958; Phleger and Soutar, 1973; Leutenegger and Hansen, 1979; Douglas, 1981; Ross and Kennett, 1983). In the California offshore basins, bolivinids are correlated with low-oxygen levels in bottom waters, but not with anoxia in sediments (Douglas, 1981). They are typical in estuarine muds-for example, the Niger Delta (Brun et al., 1982)but decrease in diversity and abundance offshore, being rarely found in abyssal areas.

Specific bolivinid morphological types are associated with different relative oxygenation levels. Thick, crenulate forms with rhomboidal cross-sections and large pores usually inhabit more oxygenated waters than flat, unornamented types with small pores (Lutze, 1977; Douglas, 1981; Boersma and Mikkelsen, this volume). Flat, unkeeled, and unornamented types with small pores are typical of quiet sedimentation under low-oxygen bottom waters where the organic carbon content of the sediments is high (Hendrix, 1958; Douglas, 1981). The modern flat, lenticular, but ornamented species Bolivina aenariensis has been associated with lowered oxygen levels at the bottom, not corresponding to the area of the organic carbon maximum (Poag, 1981). This means that this costulate form occurs at somewhat higher oxygen concentrations than species associated with the organic carbon maximum in the sediments.

In areas with low oxygen, but not anoxic conditions at the bottom, small, thin, delicate, and finely porous bolivinids proliferate (Douglas, 1981). In the Miocene of the North Atlantic and northern Indian Ocean during apparent low-oxygen episodes, the more delicate, thin, and finely porous species predominated and fluctuated together with the uvigerinids (Thomas, 1985; Boersma and Mikkelsen, this volume).

A number of other genera are associated with low-oxygen conditions at intermediate or shoaler depths. For example, the reducing, brownish-black, slope-depth sediments of Miocene age offshore West Africa contain, together with the diatoms and abundant uvigerinids, elevated numbers of Gyroidina, Praebulimina, Cassidulina, Melonis, Bulimina, allomorphinids, Valvulineria, and, in areas of very low oxygen and probably high turbidity, agglutinants such as Haplophragmoides, Cyclammina, Pavonita, Textularia, Spiroplectammina, Eggerella, and Karreriella (Brun et al., 1982, and pers. observ.).

Increased oxygenation of the intermediate depths, signaled by a decrease in low-oxygen indexes, should produce elevated abundances of benthic indexes associated with well-oxygenated conditions. Increased epifaunal abundance occurs in well-oxygenated (hereafter called oxic) areas of low-carbon rain rates in the Norwegian Sea (Corliss and Chen, 1988). In the southwest 
Table 6. Ranges of benthic foraminifers through the Oligocene at Site 216.
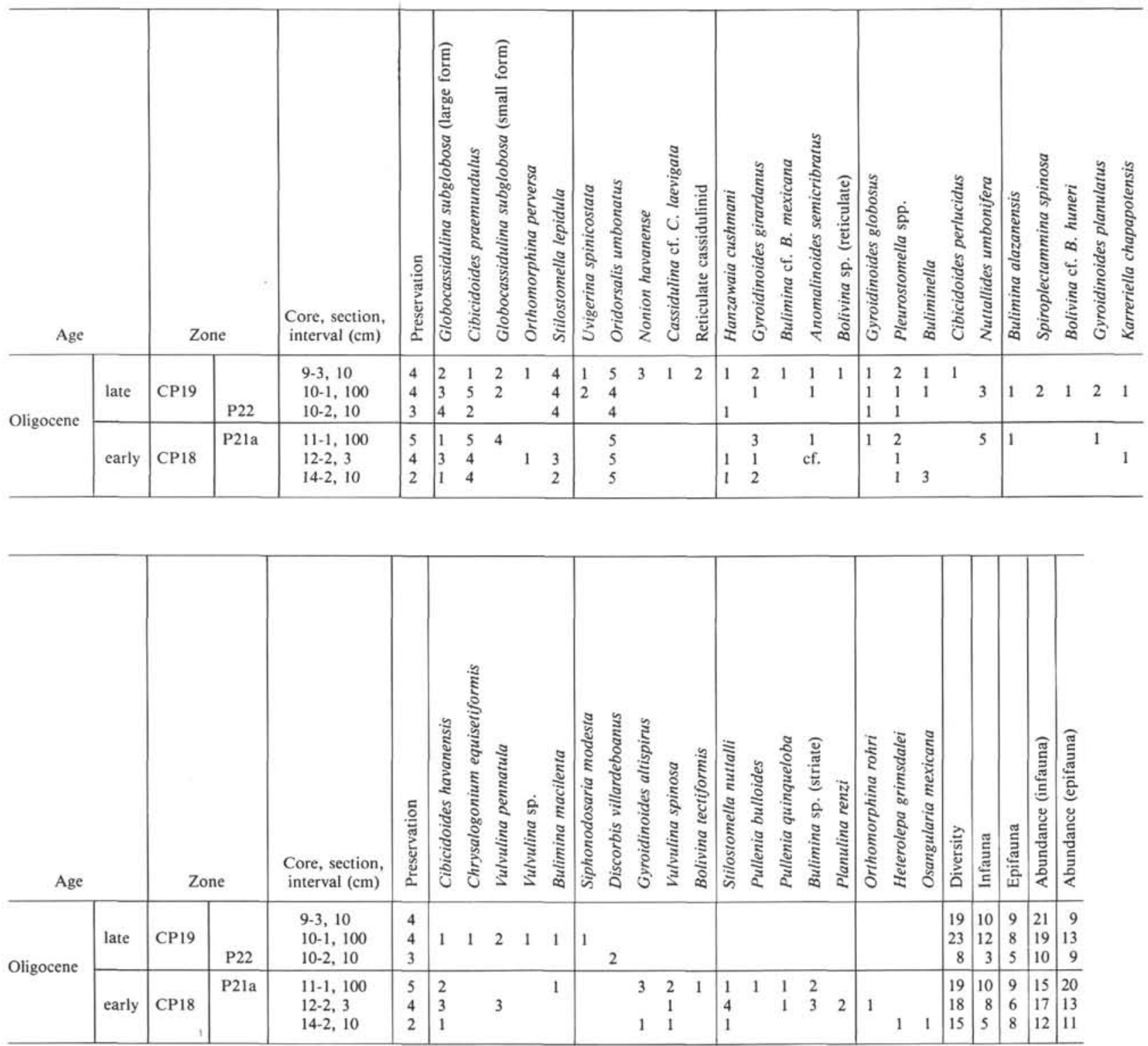

Note: Explanation as in Table 3.

Atlantic, species characterizing well-oxygenated, "new" AAIW include $G$. subglobosa, U. auberiana, B. alazanensis, $C$. wuellerstorfi, $H$. elegans, eggerellids, and various intermediate-dwelling planulinids (Corliss, 1983; Boersma, 1985a). The AAIW is well oxygenated, but less so than the NADW (Reid et al., 1977). Atlantic factor-species related to oxic conditions in NADW include C. kullenbergi, E. exiguua, N. umbonifera, G. subglobosa, $O$. umbonatus and $H$. elegans (Fig. 5). Of these, C. kullenbergi is associated with the highest oxygen values in the NADW (Woodruff and Savin, 1989). Although such forms as E. exiguua are found in abyssal waters, even at lower intermediate depths in the Norwegian Sea, $E$. exiguua inhabits well-oxygenated waters (Schnitker, 1974).

\section{Oxygenation of Intermediate Waters}

\section{Zones CN18-CN19 (= Zone P21) Time Slice}

The absence of bolivinids and a paucity of buliminids and uvigerinids in all areas, even to the north under the upwelling zone at Site 714, indicate that low-oxygen conditions in the sediments at intermediate depths did not exist in the north central Indian Ocean before the late Oligocene. The costulate index $B$. tectiformis first appeared in abundance in both the Mascarene and northern Chagos-Laccadive areas in Zone CN18 (= Zone P21a). Because of its lenticular cross-section and moderate-sized pores, and because this species is the Paleogene analog of the lenticular, finely porous, costulate bolivinid B. pusilla, which is common in the Arabian Sea today, it is considered an index for lower oxygen conditions in the sediment.

In the Mascarene and Wharton basins, intermediate-depth faunas contained abundant deep-water indexes, such as $P$. quinqueloba and $C$. praemundulus, together 'with buliminids and buliminellids, but rare bolivinids. Because $C$. praemundulus is the predecessor of the NADW index, C. kullenbergi, it is interpreted to represent well-oxygenated, deep-water conditions. At Site 707, C. praemundulus occurs together with $G$. subglobosa and alternates in abundance with the bolivinids. This suggests alternating episodes of well-oxygenated bottom waters and times 
Table 7. Ranges of benthic foraminifers through the Oligocene at Site 253.
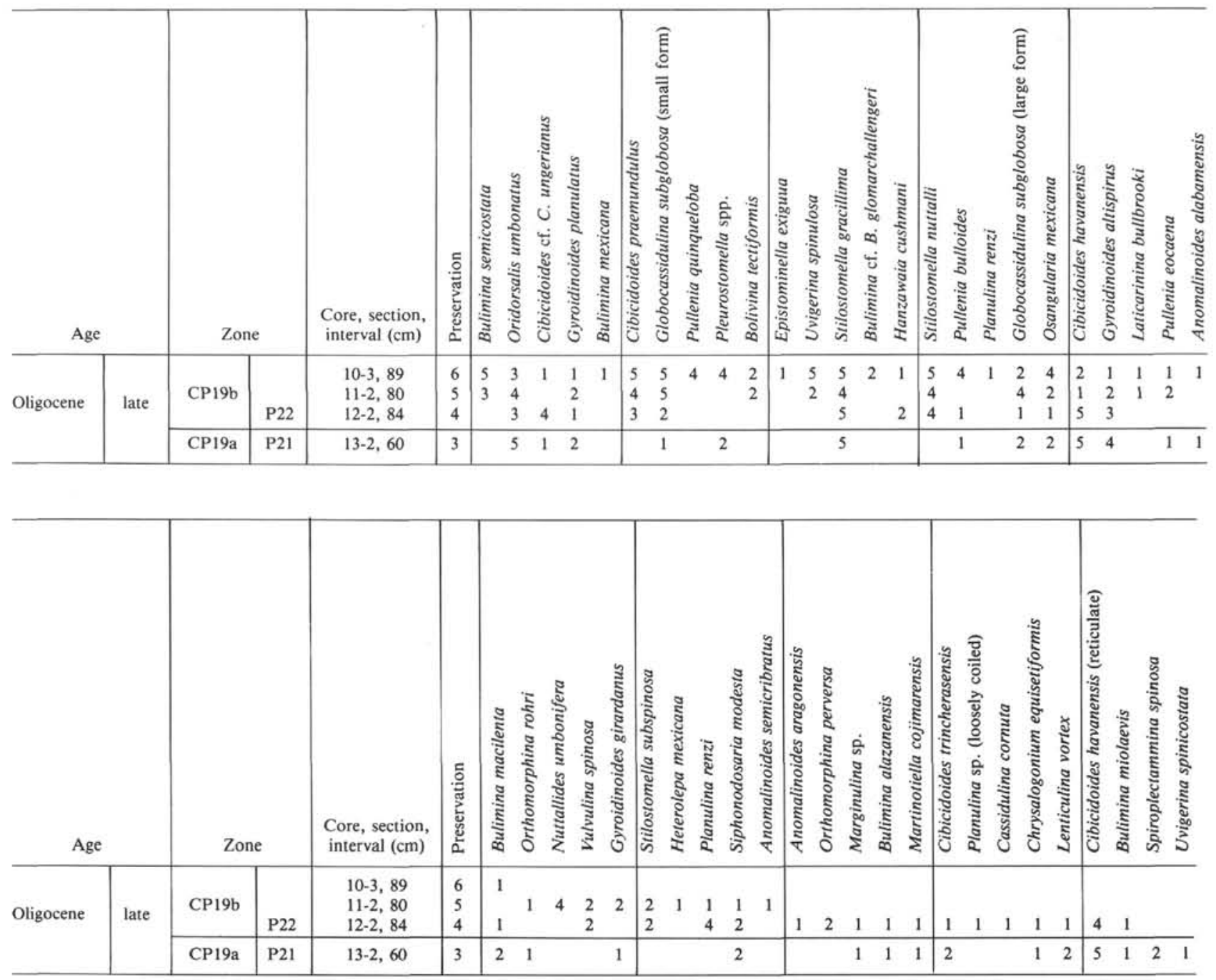

Note: Explanation as in Table 3.

of lowered oxygen at the bottom and in the sediment. Based on the similarity to modern AAIW associations, intermediate-depth faunas containing these oxic indexes are called proto-AAIW water faunas (Fig. 5).

A faunal association typified by common costulate bolivinids, but infrequent uvigerinids and rare to no $C$. praemundulus, developed during Zone $\mathrm{CN} 19$ under the southern Indian upwelling zone. At Site 714, an association, representing lower oxygen conditions in the sediment, but moderate organic carbon flux to the bottom under moderately low-oxygen bottom waters, is suggested by the absence of $C$. praemundulus, but frequency of the gyroidinids, and is called a proto-North Indian Intermediate Water (or proto-NIIW) fauna (Fig. 5). That $G$. subglobosa alternates in abundance with the bolivinids in these faunas may be a criterion for recognizing the alternation of fertile, low-oxygen conditions with only moderately fertile, moderately low-oxygen conditions under the upwelling zone.

The bolivinids and C. praemundulus are absent, and G. subglobosa is rare, in Site 253 faunas, which, however, include spinocostate uvigerinids, including the predecessor of the modern species, $U$. peregrina, together with abundant $C$. havanensis. Although the meaning of this fauna is unclear, the absence of the oxic indicators suggests that it may represent less well-oxygenated intermediate waters in an area of organic carbon accu- mulation underlying cool, fertile surface waters, as suggested by the spino-costate uvigerinids. Because of its southerly location, this fauna is called a fertile, proto-AAIW fauna (Fig. 5).

\section{Zone CN19 (Zone P22) Time Slice}

A proto-NIIW fauna characterizes all intermediate-depth sites in the Mascarene, Wharton, and Central Indian basins during late Oligocene Zone CN19. Present at all sites $(216,714,715$, and 707) are the oxic indexes G. subglobosa, C. praemundulus, or $O$. umbonatus, but the cibicidids are rare. Stilostomellids proliferate, accompanied by high numbers of a different group of bolivinids, the thick, subrhomboid forms with crenulate ornament and large pores such as B. pseudoplicata. Uvigerina spinulosa and other uvigerinids are present throughout, but most common at the very end of this time (Fig. 6). Nuttallides umbonifera and $E$. exiguua occur in pulses during this zone, but are consistently present at its end. Because of the number of epifaunal oxic indexes and the association of thick, crenulate, largepored bolivinids with moderately high oxygen concentrations in the sediment, these proto-NIIW faunas suggest elevated organic carbon contents and moderately aerated conditions in the sediments.

The association of large-pored bolivinids and uvigerinids, suggestive of high-carbon rain rates, may be related to the pene- 


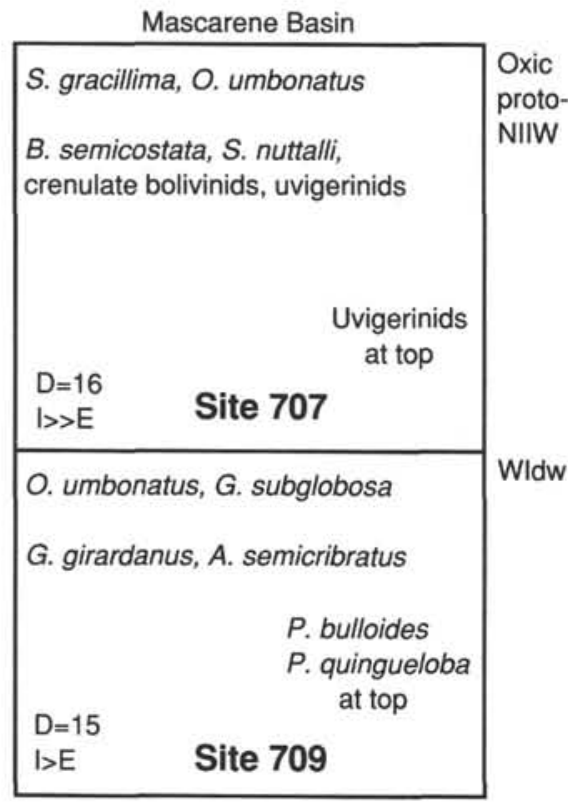

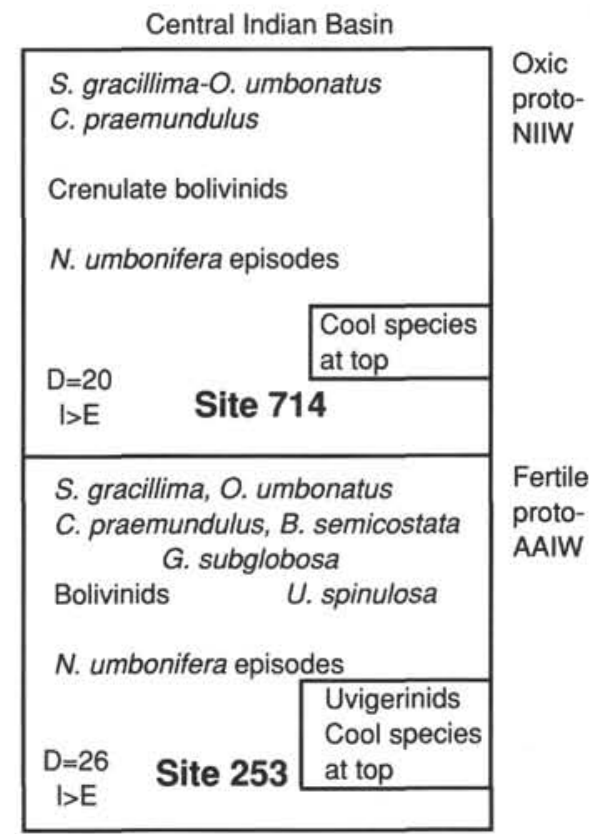

Time slice P22

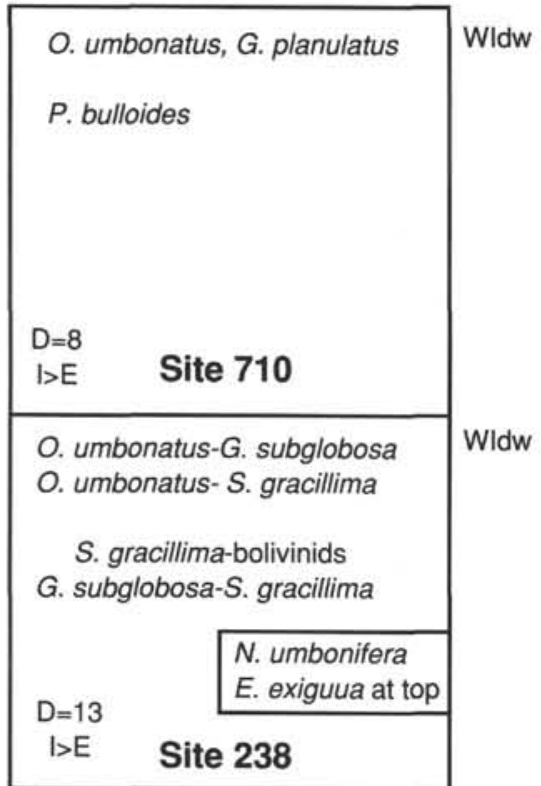

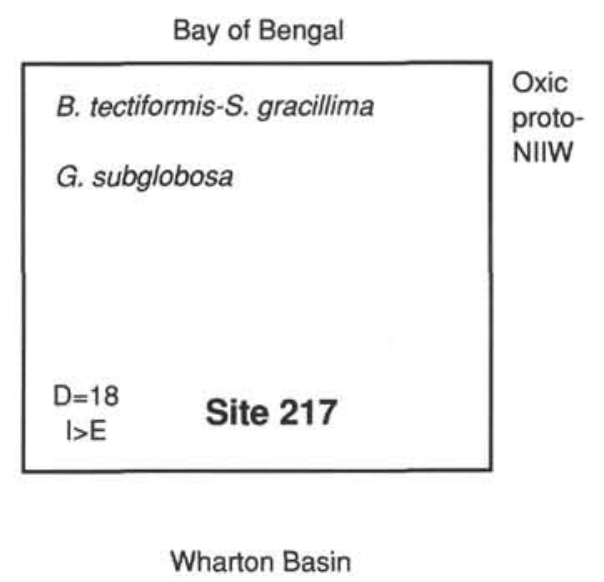

S. gracillima-O umbonatus

G. subglobosa large

G. planulatus

Cldw

Figure 6. Benthic foraminifer index faunas of late Oligocene Zone P22 (Zone CP19) from eight sites in the western and central Indian Ocean. Indexes, listed at top, were most abundant or most consistently present. Index forms that occurred only in pulses or events are shown below. Total sample diversity and the relation of infaunal to epifaunal abundance are shown at bottom left of each box. The faunal name assigned to each index fauna is listed to the right of each box. Data from Tables 3-11. 


\begin{tabular}{|c|c|c|}
\hline Zone & Miocene & \multicolumn{2}{c}{ Oligocene } \\
\hline CN1A & CP19 & CP18 \\
\hline
\end{tabular}

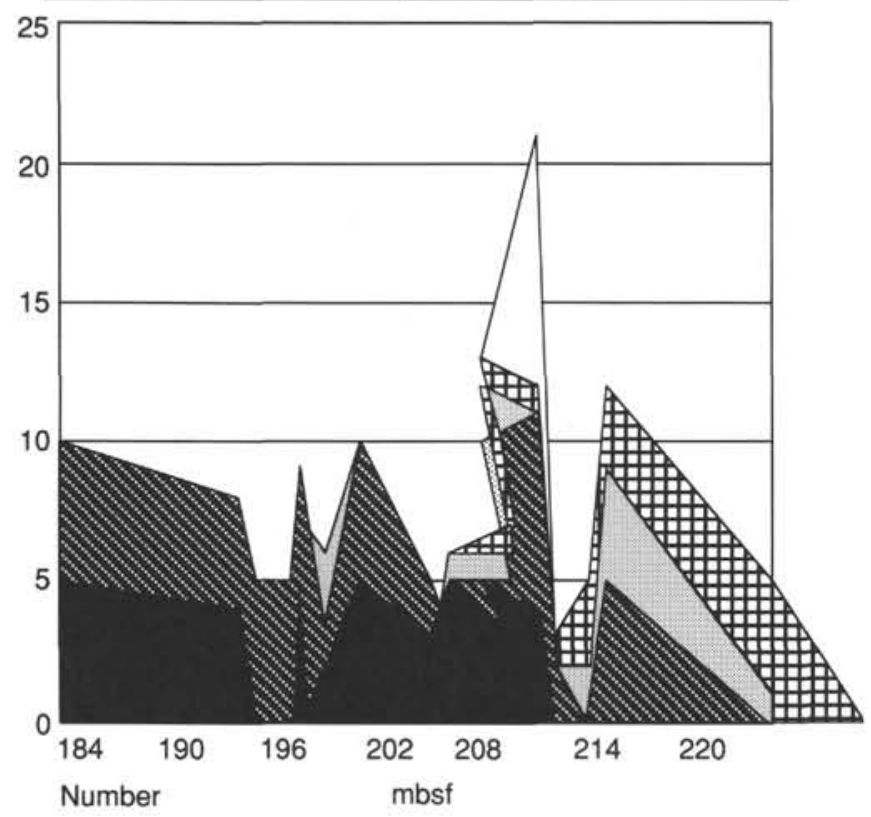

$\square$ Costulate $\mathbf{N}$ Crenulate $\square$ Reticulate B. tectiformis $\square$ Finely porous

Figure 7. Relative abundances of bolivinid species, B. pseudoplicata, $B$. reticulata, B. tectiformis, and all smooth forms with small pores combined in Hole 714A across the Oligocene/Miocene boundary. The diversity maximum in Zone CP19b may reflect the development of an oxygen minimum in the sediments. Data from Table 5 and zonation from Backman, Duncan, et al. (1988).

tration of oxygen into sediments. When the carbon rain rate is high or bottom waters are lower in oxygen, the depth of the aerated zone in the sediment decreases (Archer et al., 1989). Oxygen demand, generated by the organic carbon, increases oxygen flux into the sediment, thus increasing the oxygen content of the upper few centimeters of sediment (Jahnke et al., 1982). The large-pored bolivinids may be tracers for increased oxygen content of the upper infaunal habitat before the development of an oxygen minimum when oxygen is depleted (Boersma and Mikkelsen, this volume.

\section{Zones CN2-CN3 (Zones N4-N7) Time Slice}

More oxygenated, lower fertility conditions develop in the Mascarene Basin than in the northern Central Indian and Wharton basins at this time. Faunas containing the oxic indexes $O$. umbonatus, G. subglobosa, and $C$. kullenbergi, together with the moderately low-oxygen infaunal index $B$. pusilla, continue at Site 707 (Fig. 9). Because of the elevated numbers of displaced benthic foraminifers, it is unclear if the bolivinids at Site 707 are in place. If not, then a proto-AAIW fauna occupies intermediate depths in the northern Mascarene Basin. Because of the presence of the uvigerinids and bolivinids, this is termed a fertile, proto-AAIW fauna. This area cannot have been a source of saline, low-oxygen waters. If intermediate waters were saline, then they were a saline, oxic, or "new" water type in Zone N4.

Proto-NIIW faunas develop in the Central Indian and Wharton basins in Zone CN1 (= Zone N4) (Fig. 9). Bolivinids, pleurostomellids, stilostomellids, and infrequent uvigerinids, to- gether with consistently high numbers of globocassidulinids, characterize most faunas from 1600 to 2300 mbsl. Absent is the oxic index $C$. kullenbergi, and epifauna are infrequent. Crenulate bolivinids suggest that the sediment was moderately oxic, uvigerinids indicate moderate organic carbon content, and the lack of epifaunal oxic indexes suggest that the bottom water was only moderately oxic.

\section{Zone CN4 (Zone N9) Time Slice}

After Zone CN1 and continuing into Zone CN4 time, faunas in all areas are more similar to those under modern AAIW (Fig. 10). Benthic foraminifers are scarce, diversity is low, no uvigerinids except the oxic type $U$. auberiana are present at any site, and epifauna become more numerous than infauna for the first time at Site 707. Even in the Arabian Sea, a low-diversity fauna lacking uvigerinids, bolivinids, and buliminids develops. During the early to middle Miocene, therefore, the southern Arabian Sea did not produce high-salinity, low-oxygen intermediate waters as it does today.

Under the southern Indian upwelling zone at Site 714, a new group of bolivinids appears, albeit in low numbers, in small benthic foraminifer faunas composed of small-sized individuals. Finely porous, relatively robust bolivinids referable to $B$. pukeuriensis are accompanied by lenticular forms of $B$. striatocola, a Miocene analog of the modern species $B$. aenariensis. This species today is associated with an oxygen minimum and not the organic carbon maximum (Table 2 ), whereas the finely porous bolivinids are not the same as those delicate, thin types associated with the oxygen minimum (Douglas, 1981). This suggests that intermediate waters in the upwelling zone were moderately oxygenated, but that the upper pore waters had only moderately low oxygen levels. Because of the small faunas, low-diversity, small-sized individuals, and bolivinids, this fauna is called a moderately low-oxygen, proto-AAIW fauna (Fig. 10).

\section{Zone CN9 (= Zone N17) Time Slice}

In Zone CN9, a different faunal pattern develops in the Arabian Sea than at intermediate depths in the Mascarene Basin (Fig. 11). To the north at Site 219, an abundance pulse of spinose uvigerinids accompanies buliminids, stilostomellids, melonids, and bolivinids in very high-diversity faunas containing 46 species. In these faunas, the crenulate bolivinids are replaced by the costulate group, and the deep- and bottom-water indexes $P$. quinqueloba and $E$. exiguua migrate updepth, where they join the oxic indexes $C$. kullenbergi and $G$. subglobosa. The combined indexes suggest the development of oxygenated intermediate waters overlying sediments moderately low in oxygen, but rich in organic carbon. The presence of this fauna, called an oxic proto-NIIW fauna, suggests that saline, low-oxygen waters were not produced in the southern Arabian Sea at this time.

In contrast, a fauna containing the oxic indexes $G$. subglobosa and $U$. auberiana proliferates in the Mascarene Basin. Bolivinids, buliminids, and other indexes for lowered oxygen or greater organic carbon accumulation are absent. This fauna is called a fertile proto-AAIW fauna because uvigerinids are present and faunas are more diverse than modern faunas underlying AAIW at this site.

\section{Zones CN10-CN11 (Zones N18-N19) Time Slice}

During Zones CN10-CN11, the faunas of the Mascarene Basin and southern Arabian Sea diverged, a proto-AAIW fauna occurring to the south of the proto-NIIW fauna at Site 219 (Fig. 14). In the Arabian Sea, uvigerinids, bolivinids, buliminids, and stilostomellids occur in high-diversity faunas where the oxic cibicidid indexes and $E$. exiguua were scarce to absent, and infauna were almost four times as abundant as epifauna. Lenticular, costulate bolivinids represent moderately low-oxygen pore 
Table 8. Ranges of benthic foraminifers through the Oligocene at Site 217 .
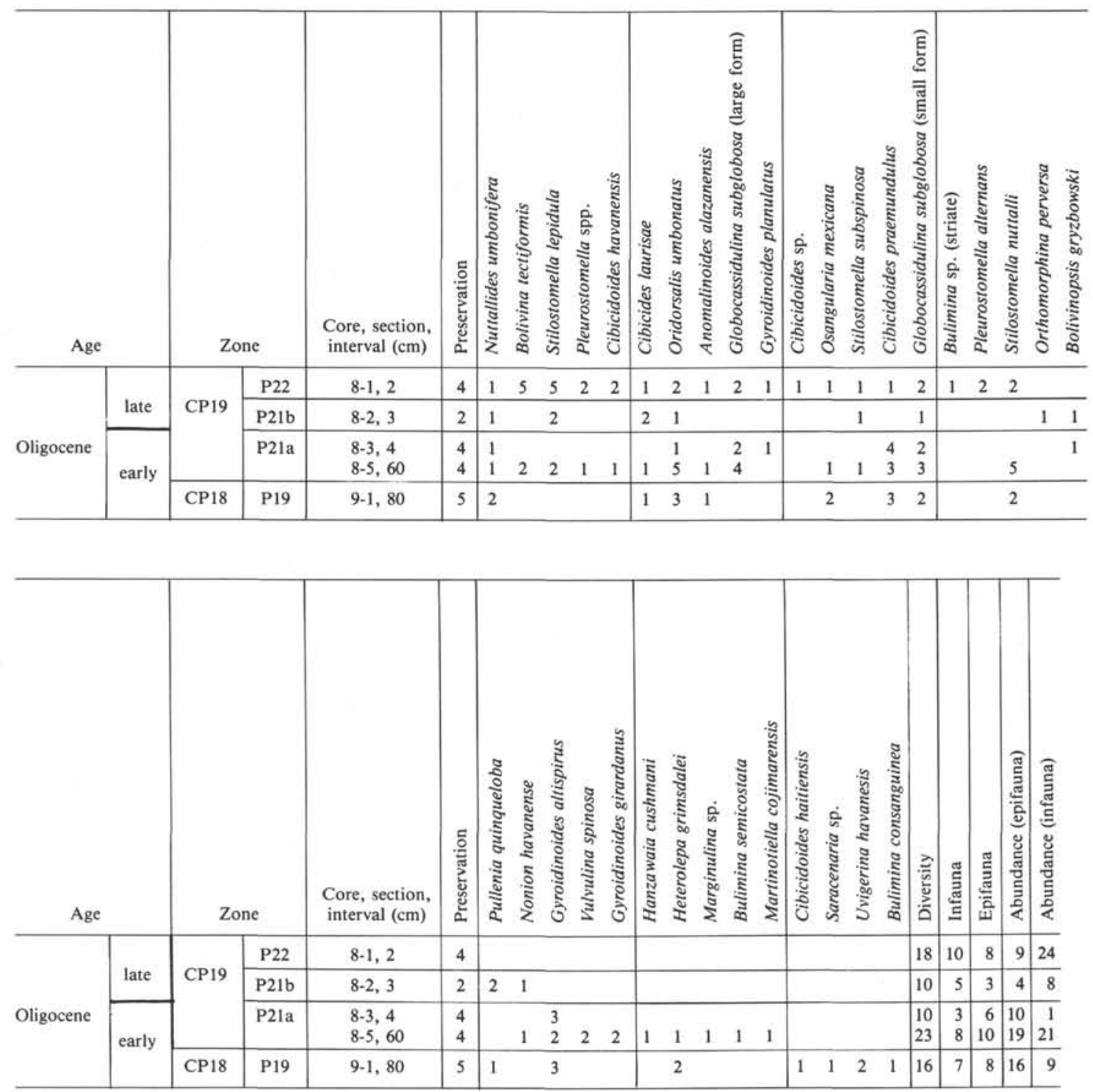

Note: Explanation as in Table 3.

waters that the presence of uvigerinids indicates are organic-carbon rich. Buliminid abundance may suggest low-oxygen intermediate waters (Table 2), in which case conditions similar to those under modern NIIW first developed in the southern Arabian Sea in the warm part of the early Pliocene (Fig. 14).

In contrast, oxic (Table 3) and bolivinid indexes for aerated pore waters occur at Site 707. These well-preserved carbonates, suggested by the presence of the lagenids, apparently underlay well-oxygenated intermediate waters, called here proto-AAIW (Fig. 14).

\section{Zone CN12 (Zone N21) Time Slice}

For the first time, a NIIW fauna occupied intermediate depths at sites ranging from the southern Arabian Sea to the northern Mascarene Basin (Fig. 16). Uvigerinids, bolivinids, stilostomellids, and $C$. wuellerstorfi are abundant, but the costulate, finely porous bolivinid $B$. pusilla typifies Site 219 . These indexes suggest that sediments were organic carbon rich and moderately low in oxygen.
The bottom-water species $E$. exiguua again migrates updepth into Site 219 , then persists into the youngest levels. The occurrence of $E$. exiguua at intermediate depths is anomalous, as this species today occurs in the factor correlated with oxygen-rich bottom waters (Fig. 5). In the southeastern Indian Ocean, its presence in IBW, in which it is co-dominant with the uvigerinids, has been related to conditions of carbonate undersaturation and low nitrite concentrations (Corliss, 1979; Peterson, 1984). The fact that $E$. exiguua migrates upward to depths near 2,000 mbsl during the coolest part of Zone N17, then again in the cooler part of the Pliocene, suggests updepth penetration of conditions typical of IBW. In the southern Arabian Sea, this water type was cool, probably well-oxygenated, and overlay lowoxygen, organic-carbon-rich sediments.

In the Mascarene Basin, elevated numbers of spinose uvigerinids occur in small, low-diversity faunas that also contain the oxic index $G$. subglobosa and crenulate bolivinids. Faunas containing infauna and uvigerinids suggestive of organic-carbonrich sediments that are oxic in the upper 1-2 cm and the underlying oxic intermediate waters are called oxic NIIW faunas. 

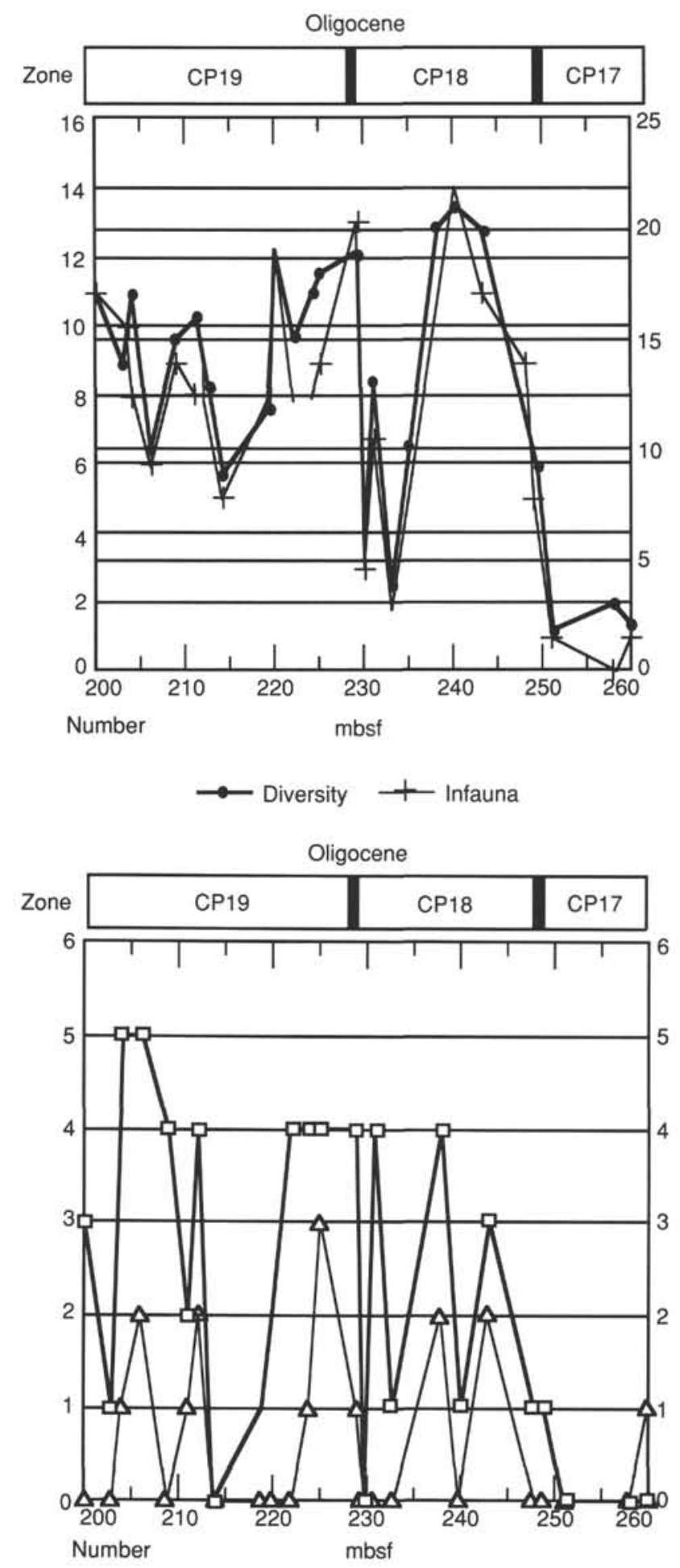

$$
\rightarrow-\text { G. subglobosa small } \quad-\Delta-\text { C. praemundulus }
$$

Figure 8. Abundances of most common species, infauna, and benthic foraminifer diversity through the Oligocene in Hole 709C. Species include Cibicidoides kullenbergi and Globocassidulina subglobosa. In Hole $709 \mathrm{C}$ samples were small and siliceous; carbonate preservation was generally poor. High infaunal abundance has been related to high carbon rain rates and elevated organic carbon content in sediments (Corliss and Chen, 1988). Because organic carbon serves as food for the foraminifers, high organic carbon content may support the higher diversity faunas. Zonation from Backman, Duncan, et al. (1988).

\section{Oxygenation Patterns and Stable Isotope Studies}

Predictions based on this study of benthic foraminifer faunas can be compared with stable isotope studies of water mass "aging" patterns through the Miocene. Benthic carbon isotope gradients from the northern Indian Ocean to the Pacific and Atlantic basins indicate that surface waters in the northern Indian Ocean were young and well oxygenated in the early and middle Miocene (Woodruff and Savin, 1989). These waters, which became oxygenated at the surface, were probably warm, yet saline enough to sink to intermediate depths. Carbon isotope gradients indicate the continuation of this pattern until $10 \mathrm{Ma}$ (in Zone CN7 = Zone N16) when new deep-water source areas developed in the Atlantic Ocean. Indian Ocean benthic foraminifer fauna patterns support the predictions of carbon isotope studies by indicating the presence of well-oxygenated waters at intermediate depths in the southern Arabian Sea and northern Mascarene Basin after Zone CN1 through the remainder of the early and early middle Miocene. In agreement with the carbon isotope data, an entirely new intermediate fauna indicating less oxic intermediate- and deep-water conditions had developed by time slice N17 (= Zone CN9) throughout the central Indian Ocean.

\section{Indian Deep-water Formation}

Although deep water in the Indian Ocean is formed today from "aged" North Atlantic Deep Water entering to the southwest, Johnson (1985) proposed that the high salinity of intermediate and deep waters in the Arabian Sea rendered them a prime deep-water source to stimulate AABW formation, especially at times when NADW formation may have been weakened or suppressed. He suggested that because evaporation in the Arabian Sea forms the deep northern salinity maximum, this saline deepwater source probably originated with the final closure of the Middle Eastern Strait, about $16 \mathrm{Ma}$, and has been operating as a deep-water source intermittently since that time.

Woodruff and Savin (1989) interpreted Miocene-age benthic carbon isotope gradients to indicate that "new," oxygen-rich, saline waters formed in the Indian Ocean, providing a deep-water source to the two adjacent oceans, from the beginning of the Miocene (24 Ma) until the late Miocene $(10 \mathrm{Ma})$ when the North Atlantic became the source of deep waters in the Atlantic basins.

Deep-water faunas and sediments from Leg 115 lend several types of evidence supporting the idea of a descending northern Indian source water. Redeposition is apparently occurring at all depths throughout the Indian Ocean (Boltovskoy, 1977; Premoli Silva and Spezzaferi, this volume). In the Mascarene Basin, redeposited intermediate-water fossils pollute the deep-water section at Site 709. More significantly, intermediate-water fossils are found redeposited throughout abyssal areas where Sites 236, 242, and 710 were drilled (Fig. 1). This erosion might be attributable to the interaction of rugged topography and a western boundary current, as in the modern Mascarene and Central Indian basins (Warren, 1981; Corliss, 1979). The displaced intermediate-depth bolivinid faunas at Site 236 in the deep Mascarene Basin, however, suggest transport not just downslope from the margin of the Mascarene Basin, but from far north on the Chagos-Laccadive Ridge because only in the northern Chagos sites do such rich and diverse bolivinid faunas occur. These patterns could be used as evidence for a vigorously sinking intermediate-water mass and a northern origin for deep waters.

\section{DEEP- AND BOTTOM-WATER STRATIFICATION}

Deep and bottom waters in the modern western Indian Ocean are derived from the Atlantic Ocean and the Atlantic sector of the Antarctic. Cold, low-salinity AABW flows north through the western basins and into the Mascarene Basin as a western 
Table 9. Ranges of benthic foraminifers through the Oligocene in Hole 710A.

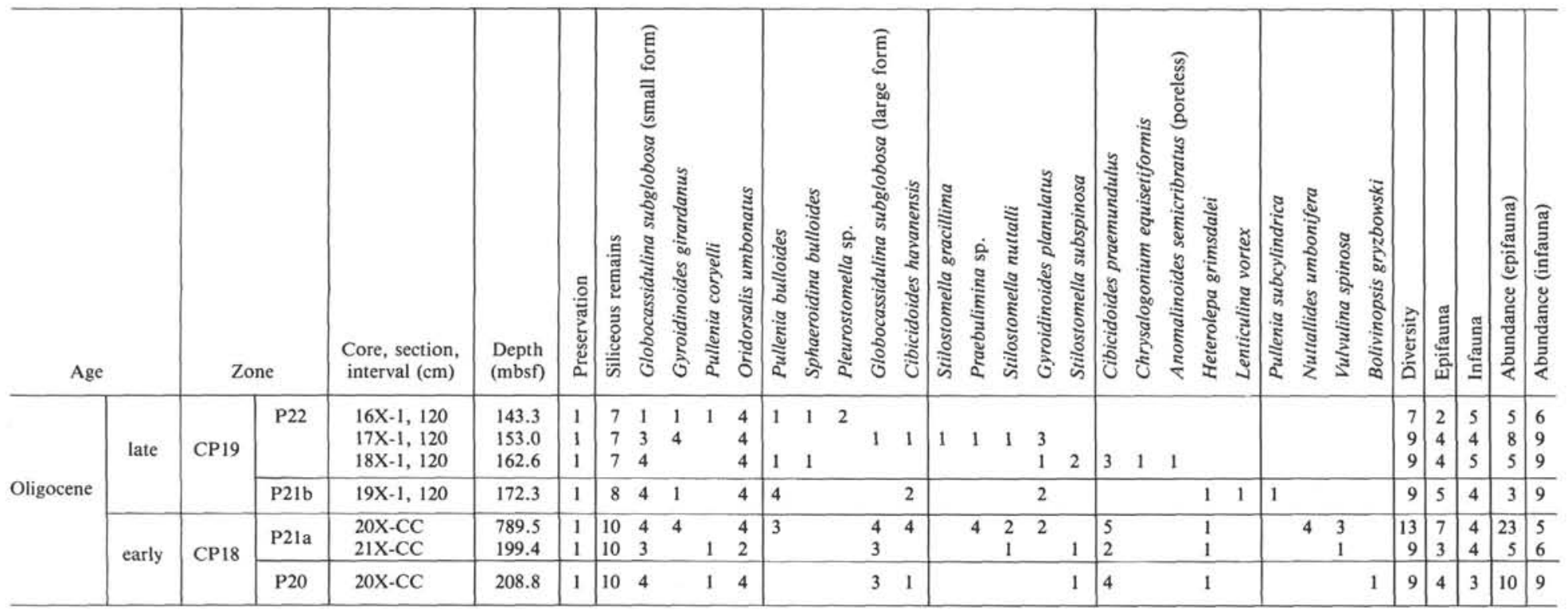


Table 10. Ranges of benthic foraminifers through the Oligocene at Site 238 .
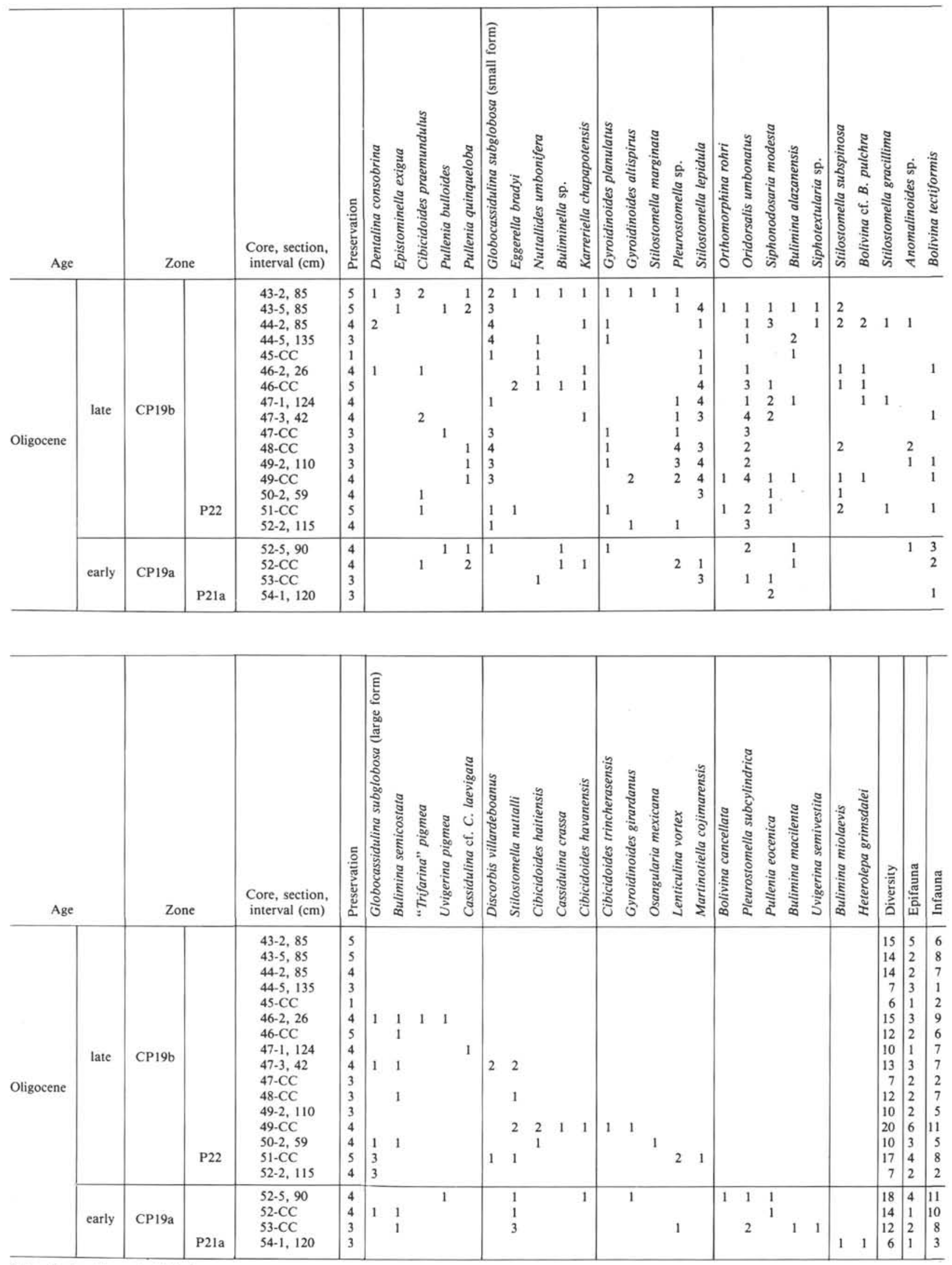

Note: Explanation as in Table 3. 
Mascarene Basin

O. umbonatus, G. subglobosa, S. gracillima, B. pusilla, S. nuttalli, C. kullenbergi

Redeposition

$D=13$

$\mathrm{I}>\mathrm{E}$

Site 707

S. gracillima, B. tectiformis, G. subglobosa,

C. praemundulus, uvigerinids

Decreased diversity

$S$. lepidula increase

in Zone N4

D-14

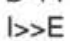

\section{Site 237}

Fertile

proto-

AAIW

Fertile

proto-

AAIW

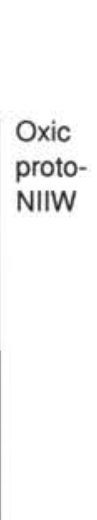

Arabian Sea

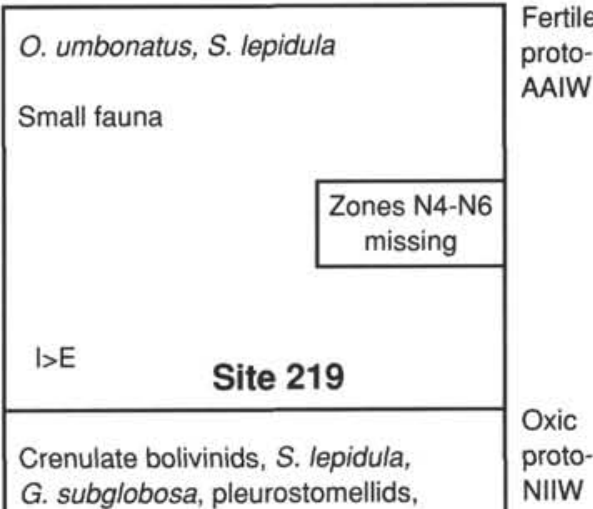

South Indian Upwelling

Crenulate bolivinids, $S$. lepidula,

Bolivinita, B. pusilla, G. subglobosa

Oxic

proto-

NIIW

G. subglobosa, B. semicostata,

$O$. umbonatus-S. lepidula,

uvigerinids

\begin{tabular}{ll|} 
Decreased diversity \\
$\begin{array}{c}D=12 \\
l>E\end{array}$ & $\begin{array}{c}\text { Uvigerinids } \\
\text { at top } \\
\text { N4 }\end{array}$ \\
\hline
\end{tabular}

Time slice

N4-N7

\section{$\underset{I>E}{D=13} \quad$ Site 710}

Figure 9. Benthic foraminifer index faunas of early Miocene Zones N4-N7 (= Zones CN1-CN3) from seven sites in the western and central Indian Ocean. Indexes, listed at top, were most abundant or most consistently present. Index forms that occurred only in pulses or events are shown below. Total sample diversity and the relation of infaunal to epifaunal abundance are shown at bottom left of each box. The faunal name assigned to each index fauna is listed to the right of each box. Data from Tables 12-16. 
Table 11. Ranges of benthic foraminifers through the Oligocene in Hole $709 \mathrm{C}$.

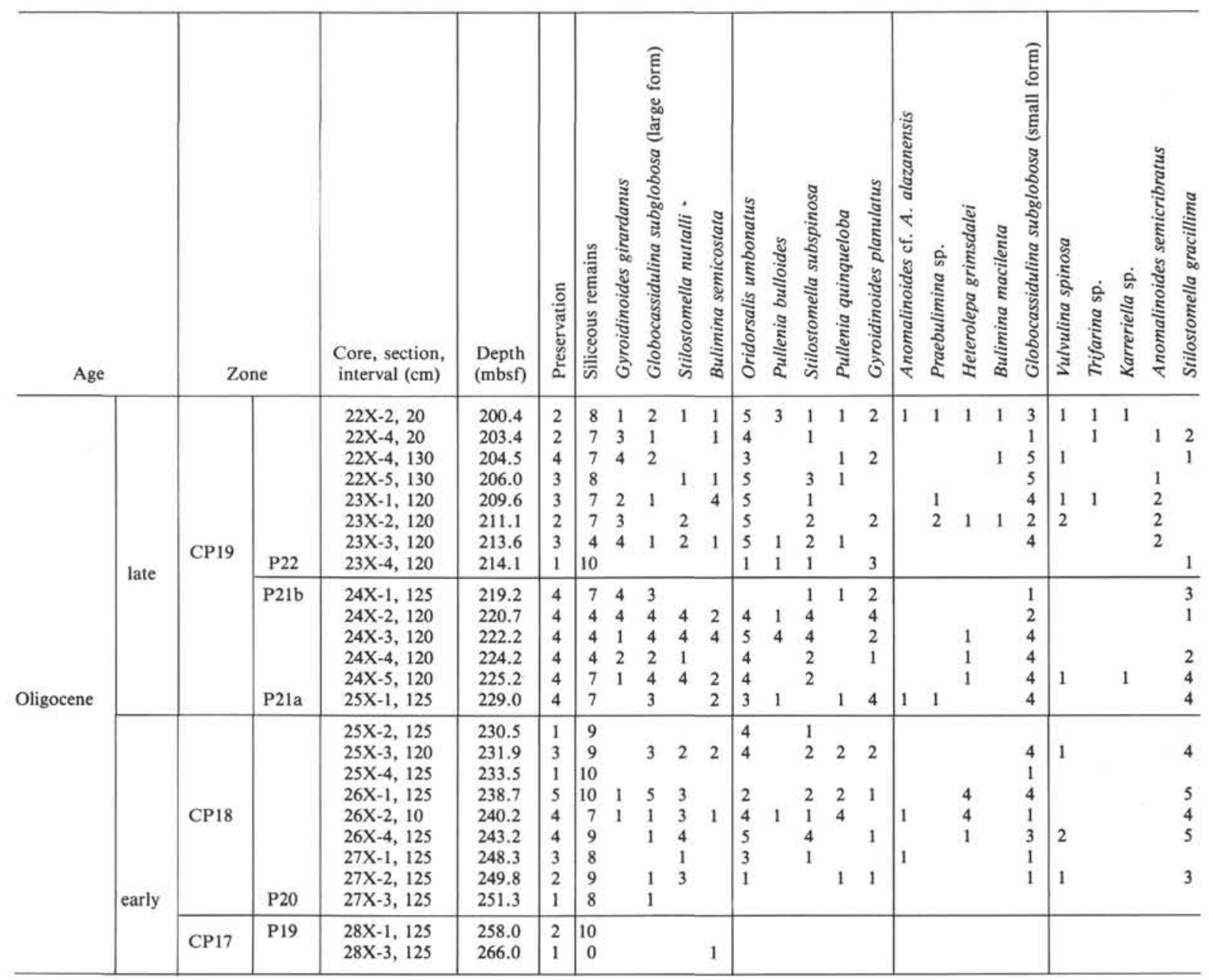

Note: Explanation as in Table 3.

boundary current. Warm, high-salinity deep waters, produced by "aging" of NADW that enters to the south of South Africa, also flow northward through the Mascarene Basin as a western boundary current. Circumpolar water flows northward along the Central Indian Ridge (Wyrtki, 1973; Warren, 1981; Corliss, 1983; Peterson, 1984; Johnson, 1985).

Modern deep and abyssal faunas associated with these water types resemble their Atlantic and southeast Indian ocean counterparts. Nuttallides umbonifera characterizes the coldest bottom water of Antarctic origin, distinguished from the overlying deep water largely by its temperature and salinity minimum. This cold AABW is undersaturated with respect to calcite because of the high $\mathrm{CO}_{2}$ productivity on the Antarctic continental shelf. Cold, "new" bottom waters in the abyssal northeastern Atlantic are associated with the factor-species $E$. exiguua, $C$. wuellerstorfi, $O$. umbonatus, $N$. umbonifera, $N$. pompilioides, $M$. barleanuum, $P$. bulloides, $C$. robertsonianus, $E$. bradyi, and $C$. kullenbergi. During glacial episodes, this abyssal factor-association includes the uvigerinids, globobuliminids, and $B$, alazanensis (Schnitker, 1979).

In the southeast Indian Ocean, well-oxygenated AABW derived from the southern Indian Basin is associated with the factor-species $P$. wuellerstorfi, N. umbonifera, P. bulloides, M. pompilioides, and $O$. umbonatus. No uvigerinids or Nonion are found in faunas in this water mass. An overlying, warmer AABW that fills most of the eastern abyssal basins is characterized by the factor-species G. subglobosa, Astrononion sp., O. umbonatus, G. soldanii, P. bulloides, and C. wuellerstorfi (Corliss, 1979).

In both the southeast Indian Ocean and Central Indian Basin, Indian Bottom Water (IBW), produced from a mixture of CPDW and AABW, is slightly higher in temperature and salinity, but slightly lower in dissolved oxygen. This water is less undersaturated with respect to calcite because of its production in warmer water at shoaler depths (Corliss, 1979). Characteristic factor-species include the uvigerinids and E. exiguua, with Pyrgo spp., Astrononion sp., C. kullenbergi, O. umbonatus, miliolids, and lagenids. Dominance of this factor-association suggests decreased AABW input to the South Indian Basin (Corliss, 1979). Shoaling of the AABW fauna, in contrast, suggests increased bottom-water circulation (Corliss, 1979).

Warm, high-salinity deep water in the southwest Indian Ocean is characterized by the factor-species Astrononion echolsi, $P$. bulloides, G. subglobosa, and C. wuellerstorfi (Corliss, 1983). This water type is formed by the "aging" of NADW, which is associated with the factor-species $G$. subglobosa, U. peregrina, O. umbonatus, C. wuellerstorfi, C. kullenbergi, H. elegans, and the miliolids in the southwest Atlantic Ocean (Lohmann, 1978; Corliss, 1983). Less saline deep waters in the southeastern 
Table 11 (continued).

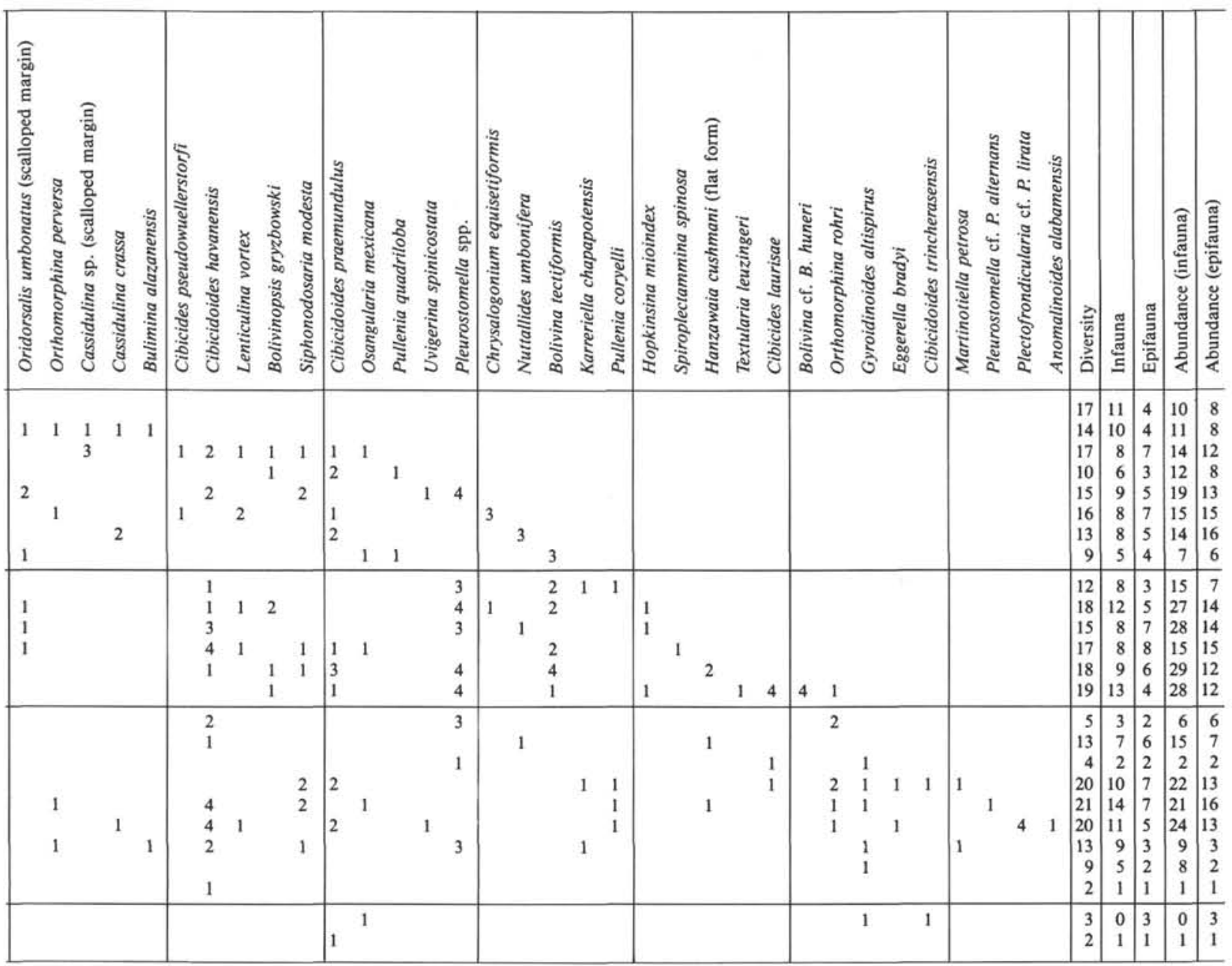

Indian Ocean, however, are associated with factor-species of uvigerinids, together with miliolids and $G$. subglobosa (Peterson, 1984).

Circumpolar deep waters are lower in oxygen and higher in temperature and display a salinity maximum. Most typical of this water type are the uvigerinids, which occur in the higher latitude South Atlantic and the southeastern Indian Oceans, but not in the modern Mascarene Basin. Indexes for this water mass include $C$. carinata, $P$. bulloides, $B$. aculeata, and in the South Atlantic Astrononion (Corliss, 1983; Hodell et al., 1985; Clarke and Wright, 1984; Boersma, 1985b; Mead, 1985).

Deep and abyssal faunas from the Leg 115 traverses, although reduced by dissolution and polluted by redeposition, retain unique signatures resulting in more or less faunal similarity with depth and between basins. Faunal similarity with depth increases: (1) during the early late Oligocene and most of the early to middle Miocene when deep-water indexes expanded into abyssal depths; and (2) in the latest Oligocene, episodically in the earliest Miocene, and in the late Pliocene when abyssal indexes migrated upslope. Similarity of deep and abyssal faunas has been interpreted to indicate the diminution of either deep- or bottom-water formation (Hodell et al., 1985), or similarity of source regions (Woodruff and Savin, 1989).

\section{Oligocene}

By Zone CN18 time, there was an expansion to all depths of indexes for well-oxygenated waters, such as $C$. praemundulus, the progenitor of the modern, well-oxygenated NADW index, C. kullenbergi (Fig. 5). Also present are other oxygenated-water-mass indexes, including $N$. umbonifera, G. subglobosa, and the pullenids. These faunas, suggesting a well-oxygenated, deep-water mass, range in depth from Site 709 to abyssal Site $710(2800-3800 \mathrm{mbsl})$ in the Mascarene Basin and are termed oxic Western Indian deep water (WIdw) faunas (Fig. 5). Homogeneity with depth of deep-water indexes for well-oxygenated conditions may indicate a similar and local source region for deep and bottom waters in the Mascarene Basin. Clearly, in the Oligocene they were not formed by aging of a deep-water mass derived from the Atlantic.

The development of a G. subglobosa-O. umbonatus-N. umbonifera bottom-water index fauna in one episode at Site 709 (Fig. 5) suggests increased bottom-water formation or decreased deep-water formation (Hodell et al., 1985), and/or dissimilar source regions. This fauna is similar to the faunal-factor associated with modern IBW in the southeastern Indian Ocean, a water mass that is cold, low in salinity, and well oxygenated (Peterson, 1984).

In the Mascarene and Central Indian basins, deep-water faunas such as those found at Site $238(2826 \mathrm{mbsl})$ resemble faunas updepth and contain such intermediate-depth indexes as Uvigerina semivestita (Boersma, 1984). If these species are in place, then homogeneity from intermediate to abyssal areas of faunas suggesting well-oxygenated conditions may indicate that the source area of these water masses is localized in the northern Indian Ocean beginning in the late Oligocene. 
Table 12. Ranges of benthic foraminifers through the Miocene in Hole 707A.

\begin{tabular}{|c|c|c|c|c|c|c|c|c|c|c|c|c|c|c|c|c|c|c|c|c|c|c|c|c|}
\hline \multicolumn{2}{|c|}{ Age } & \multicolumn{2}{|c|}{ Zone } & \multirow{2}{*}{$\begin{array}{l}\begin{array}{l}\text { Core, section, } \\
\text { interval }(\mathrm{cm})\end{array} \\
11 \mathrm{H}-1,70 \\
11 \mathrm{H}-\mathrm{CC}, 120 \\
12 \mathrm{H}-1,120 \\
12 \mathrm{H}-2,120\end{array}$} & \multirow{2}{*}{$\begin{array}{c}\begin{array}{c}\text { Depth } \\
\text { (mbsf) }\end{array} \\
93.9 \\
? \\
104.0 \\
105.5 \\
\end{array}$} & & \multicolumn{5}{|c|}{ 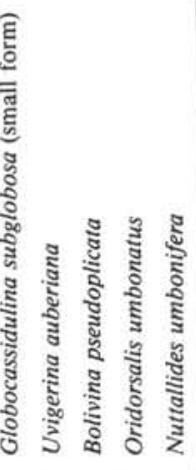 } & 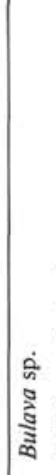 & \multicolumn{4}{|c|}{ 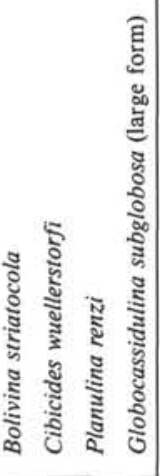 } & 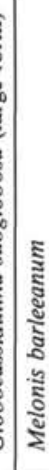 & 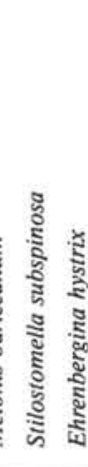 & \multicolumn{2}{|c|}{ 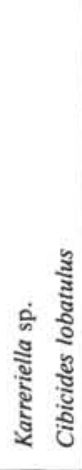 } & \multicolumn{2}{|c|}{ 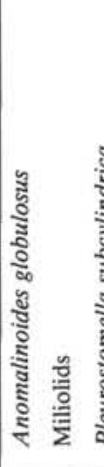 } & 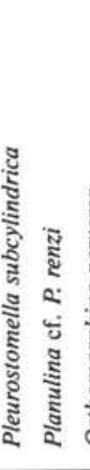 & 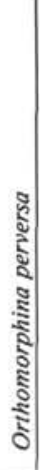 \\
\hline \multirow{7}{*}{ Miocene } & \multirow{4}{*}{ late } & CN8 & & & & $\begin{array}{l}7 \\
7 \\
6 \\
6\end{array}$ & $\begin{array}{l}5 \\
1 \\
3 \\
\end{array}$ & $\begin{array}{l}4 \\
1 \\
3\end{array}$ & $\begin{array}{l}4 \\
4\end{array}$ & 3 & & $\begin{array}{l}5 \\
2 \\
2\end{array}$ & 3 & & & $\begin{array}{l}1 \\
3 \\
1\end{array}$ & 1 & 1 & 1 & & 11 & $\begin{array}{l}1 \\
1 \\
\end{array}$ & 1 & 1 \\
\hline & & $\mathrm{CN} 7$ & N13-N15 & $\begin{array}{l}12 \mathrm{H}-3,120 \\
12 \mathrm{H}-4,120 \\
12 \mathrm{H}-3,121 \\
12 \mathrm{H}-6,114\end{array}$ & $\begin{array}{l}107.0 \\
108.5 \\
110.0 \\
111.4\end{array}$ & $\begin{array}{l}5 \\
5 \\
6 \\
6\end{array}$ & $\begin{array}{l}4 \\
4\end{array}$ & 1 & 1 & $\begin{array}{l}1 \\
5 \\
1 \\
2 \\
2\end{array}$ & 1 & $\begin{array}{l}1 \\
5 \\
3\end{array}$ & & $\begin{array}{l}1 \\
3 \\
2 \\
1\end{array}$ & $\begin{array}{l}1 \\
1 \\
1\end{array}$ & 1 & & $\begin{array}{l}2 \\
1 \\
5\end{array}$ & 1 & & & 1 & $\begin{array}{l}3 \\
1 \\
1\end{array}$ & 1 \\
\hline & & $\mathrm{CN} 5 \mathrm{~b}-\mathrm{CN} 5 \mathrm{c}$ & \multirow[b]{2}{*}{$\mathrm{N} 13$} & $\begin{array}{l}13 \mathrm{H}-1,120 \\
13 \mathrm{H}-2,120 \\
13 \mathrm{H}-3,170 \\
13 \mathrm{H}-4,120\end{array}$ & $\begin{array}{l}113.6 \\
115.1 \\
116.6 \\
118.1 \\
\end{array}$ & $\begin{array}{l}6 \\
6 \\
6\end{array}$ & 4 & 1 & 1 & $\begin{array}{ll}1 & 1 \\
1\end{array}$ & 1 & 1 & 3 & $\begin{array}{l}3 \\
3 \\
3\end{array}$ & 1 & $\begin{array}{l}1 \\
1 \\
1\end{array}$ & & & & & \multicolumn{4}{|c|}{$\begin{array}{l}3 \\
4\end{array}$} \\
\hline & & CN5a & & $13 \mathrm{H}-5,121$ & 119.6 & 5 & 1 & 1 & 5 & 1 & & & 5 & 1 & & & & & & & & & & 1 \\
\hline & middle & $\mathrm{CN} 4$ & $\mathrm{~N} 10-\mathrm{N} 12$ & $\begin{array}{l}11 \mathrm{H}-1,120 \\
11 \mathrm{H}-2,120 \\
11 \mathrm{H}-3,120\end{array}$ & $\begin{array}{l}123.2 \\
124.7 \\
126.2\end{array}$ & $\begin{array}{l}5 \\
5 \\
5\end{array}$ & $\begin{array}{l}1 \\
2\end{array}$ & & 1 & & & 2 & & 1 & 1 & 1 & & $\begin{array}{l}1 \\
1\end{array}$ & & & & & & \\
\hline & \multirow[t]{2}{*}{ early } & $\begin{array}{l}\mathrm{CN} 3 \\
\mathrm{CN} 2\end{array}$ & $\mathrm{~N} 5-\mathrm{N} 7$ & $\begin{array}{l}15 \mathrm{H}-2,121 \\
15 \mathrm{H}-3,120 \\
15 \mathrm{H}-4,120 \\
15 \mathrm{H}-5,120\end{array}$ & $\begin{array}{l}134.3 \\
135.8 \\
137.3 \\
138.8 \\
\end{array}$ & $\begin{array}{l}4 \\
4 \\
3 \\
6 \\
\end{array}$ & $\begin{array}{l}4 \\
5 \\
4\end{array}$ & & & $\begin{array}{l}1 \\
1 \\
4 \\
4\end{array}$ & & & $\begin{array}{l}1 \\
1 \\
2 \\
\end{array}$ & & & 4 & \multicolumn{4}{|c|}{1} & \multicolumn{4}{|c|}{1} \\
\hline & & $\mathrm{CNla}$ & $\mathrm{N} 4$ & $15 \mathrm{H}-6,56$ & 139.7 & 6 & & & & 1 & & & 4 & & & & & & & & & & & \\
\hline
\end{tabular}

Note: Explanation as in Table 3.

After the early warm part of Zone CP19 (Zone P22), a homogeneous benthic fauna again developed at deep and abyssal depths in the western Indian Ocean (Fig. 6). The preservation of carbonate became poorer, despite which diversity increased. Widespread development with depth and latitude of $O$. umbonatus, G. subglobosa, and the gyroidinids suggests expansion of an oxygenated deep-water mass. Because gyroidinids are associated with only moderately ventilated water masses today (Table 3), the troposphere was possibly less well oxygenated than earlier in Zone CP18 when C. praemundulus was ubiquitous. This fauna is called the moderately oxic WIdw fauna.

Deep-water faunas of the Central Indian Basin and Bay of Bengal were similar to lower intermediate water (2252-2262 mbsl) faunas living in the Wharton and Mascarene basins, and to the south on the middle latitude portion of the Ninetyeast Ridge (Fig. 6). These faunas contain more infauna and numerous indexes for lower oxygen conditions, including bolivinids and buliminids (Table 2). Deep-water faunas at Sites 709 and 710 in the Mascarene Basin do not include these indexes, being dominated instead by such indexes for moderately well-oxygenated water masses as $G$. subglobosa, $O$. umbonatus, and $P$. bulloides. The deep-water faunas of the Bay of Bengal and Central Indian Basin, called here the Central Indian deep-water fauna, indicate lower oxygen at the bottom, while a moderately oxic WIdw fauna persisted through depth in the western basin.

The absence of a bottom-water fauna is indicated by the widespread development of deep-water indexes through depth and by the scarcity of $N$. umbonifera and E. exiguua in the Oli- gocene (Fig. 6). At the end of Zone CN19, however, several species associated with AABW today, including $N$. umbonifera, $E$. exiguua, and $P$. quinqueloba migrated upward into deep-water sites of the Mascarene and Central Indian basins. This indicates that cold, low-salinity bottom water with characteristics like modern AABW first entered the northern Indian Ocean in pulses near the end of the Oligocene. The updepth expansion of bottom-water indexes reflects either increased bottom water or decreased deep-water formation; a southern source for oxygenated bottom waters was apparently developed at this time.

\section{Miocene}

The early Miocene is characterized by faunal homogenization with depth, which is mirrored by the continuing low thermal and carbon isotope contrasts through the water column (Vincent et al., 1985). Faunas at Site 710 in the Mascarene Basin contain the modern NADW index C. kullenbergi, associated with $G$. subglobosa and N. umbonifera. The presence of these indexes indicates that a well-oxygenated, deep-water mass extended from $2800 \mathrm{mbsl}$ to $3800 \mathrm{mbsl}$ in the Mascarene Basin through most of the early Miocene. This fauna is called the cold, oxic Western Indian Deep Water (WIdw) fauna (Fig. 9).

Continuing from Zone CN1 through most of the early Miocene and earliest middle Miocene Zone CN4, abyssal and deepwater faunas displayed a high degree of similarity, indicated by the widespread distribution of the O. umbonatus-C. kullenbergi index fauna and the updepth migration of $N$. umbonifera into deep-water sites (Fig. 9). This fauna indicates well-oxygen- 
Table 12 (continued).

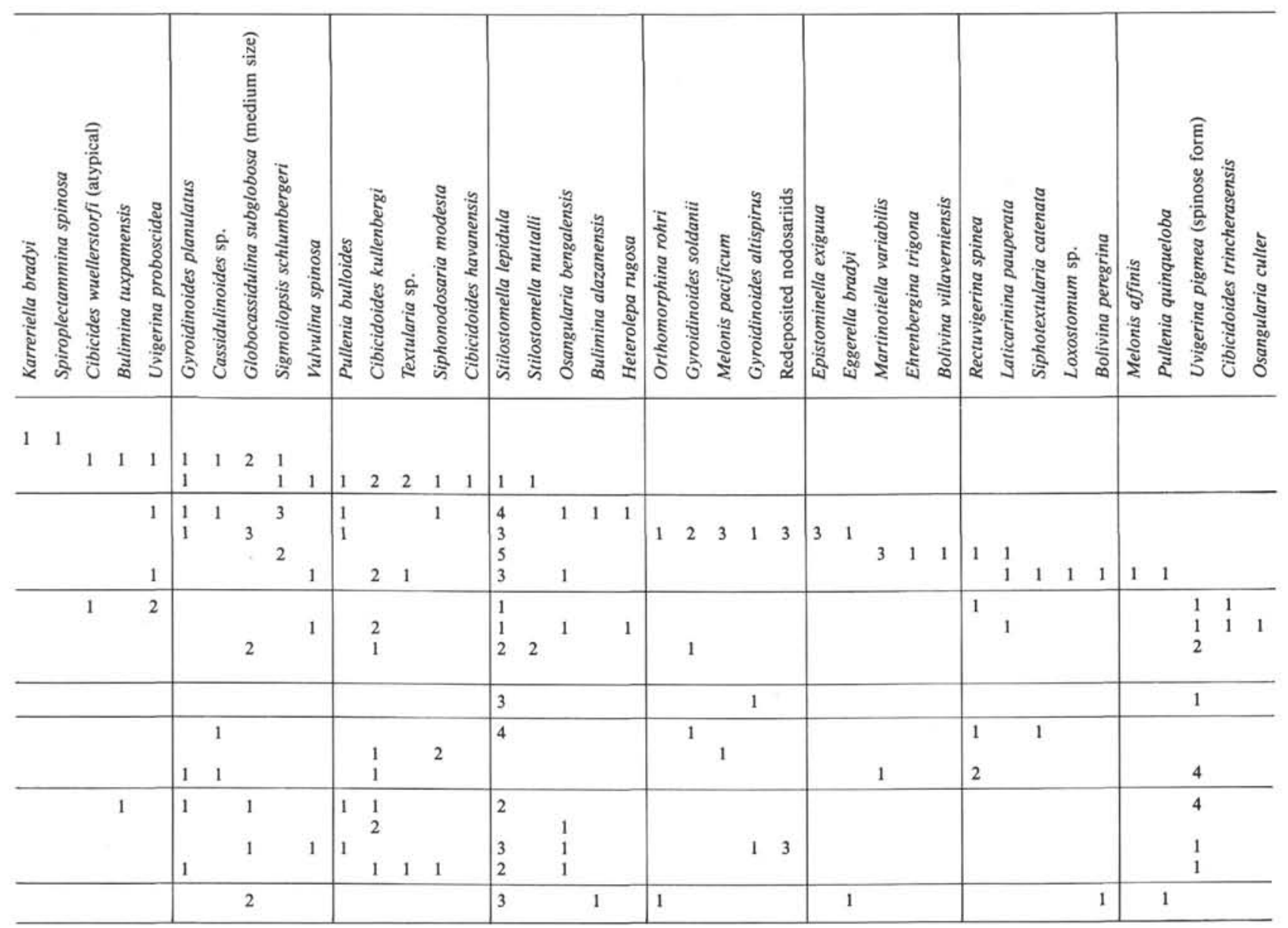

ated deep and bottom waters (Table 2) that may have been corrosive to carbonates (Bremer and Lohmann, 1982). Deep-water faunas at Sites 709 and 237, however, contain numerous forms in common with overlying intermediate-depth faunas. These include the infaunal indexes for lower oxygen conditions and elevated sediment organic carbon content, the bolivinids, stilostomellids, and uvigerinids. The prevalence of mottled sediment throughout this interval indicates that infaunal predators were common and, hence, that their food supply was high. The similarity between deep- and intermediate-depth faunas, then, suggests episodes either of increased redeposition or of enhanced preservation of organic carbon and lower oxygen conditions in the sediment, possibly resulting from redeposition as well.

Late Miocene Zone CN9 is characterized by faunal heterogeneity and the development of modern water-mass types in both the Central Indian and Mascarene basins. Bolivinids increase in deep-water Sites 709 and 713 early in the zone, suggesting lowered oxygen levels in the sediments (Fig. 11). The proliferation of spinose uvigerinids midway through the zone, although in generally low numbers, is coeval with the Epoch 6 carbon shift (Lutze, 1977; Vincent et al., 1980; Woodruff, 1985; Vincent et al., 1985; Boersma, 1985c; Woodruff et al., this volume). It has been proposed that more organic carbon was deposited in the ocean at this time, increasing oxygen demand in the water column and producing a widespread oxygen minimum zone under which carbonate preservation improved.

At Site 713, an O. umbonatus-B. alazanensis-Uvigerina-C. kullenbergi index fauna containing lagenids and crenulate bolivinids develops in Zone CN9 (Fig. 11). This expansion of uvi- gerinids and other infaunal indexes for lower oxygen and enhanced organic carbon preservation in the sediments, as well as increased overhead primary production, is related to the increased rates of carbonate accumulation registered in the Mascarene Basin and elsewhere (Lutze, 1977; Vincent et al., 1980; Boersma, 1985c; Peterson and Backman, this volume). Because of the presence of uvigerinids and its similarity to the factorfauna associated with modern IDW in the Central Indian Basin, this fauna is called a less oxygenated, proto-IDW fauna. Its dissimilarity from modern IDW-related assemblages is based on the crenulate bolivinids that are not present today, and so suggest only moderately oxygenated, not well-oxygenated, pore waters in Zone CN9. Modern IDW is less undersaturated with respect to calcium carbonate; the evolution of this well-saturated water type may also be related to the improved carbonate preservation registered in Zone CN9 (Heirtzler et al., 1977; Corliss, 1983; Peterson and Backman, this volume).

Near the end of Zone CN9, when bolivinids disappear from deep-water faunas, the remaining indexes suggest increased oxygenation at the bottom (Fig. 11). In the abyssal Mascarene Basin, a fauna typical of modern AABW, including N. umbonifera, C. wuellerstorfi, E. exiguua, and $O$. umbonatus, developed at abyssal Site 710. Because these factor-species are associated with low salinity, corrosive, and very cold Weddell Sea Water and AABW today (Bremer and Lohmann, 1982; Corliss, 1983; Mead, 1985), this water mass at Site 710 is called proto-AABW.

Factor-species related to IDW, such as F. fava, O. umbonatus, and G. subglobosa, proliferated upslope at Site 709, although uvigerinids, lagenids, miliolids, and $C$. kullenbergi are 
Table 12 (continued).

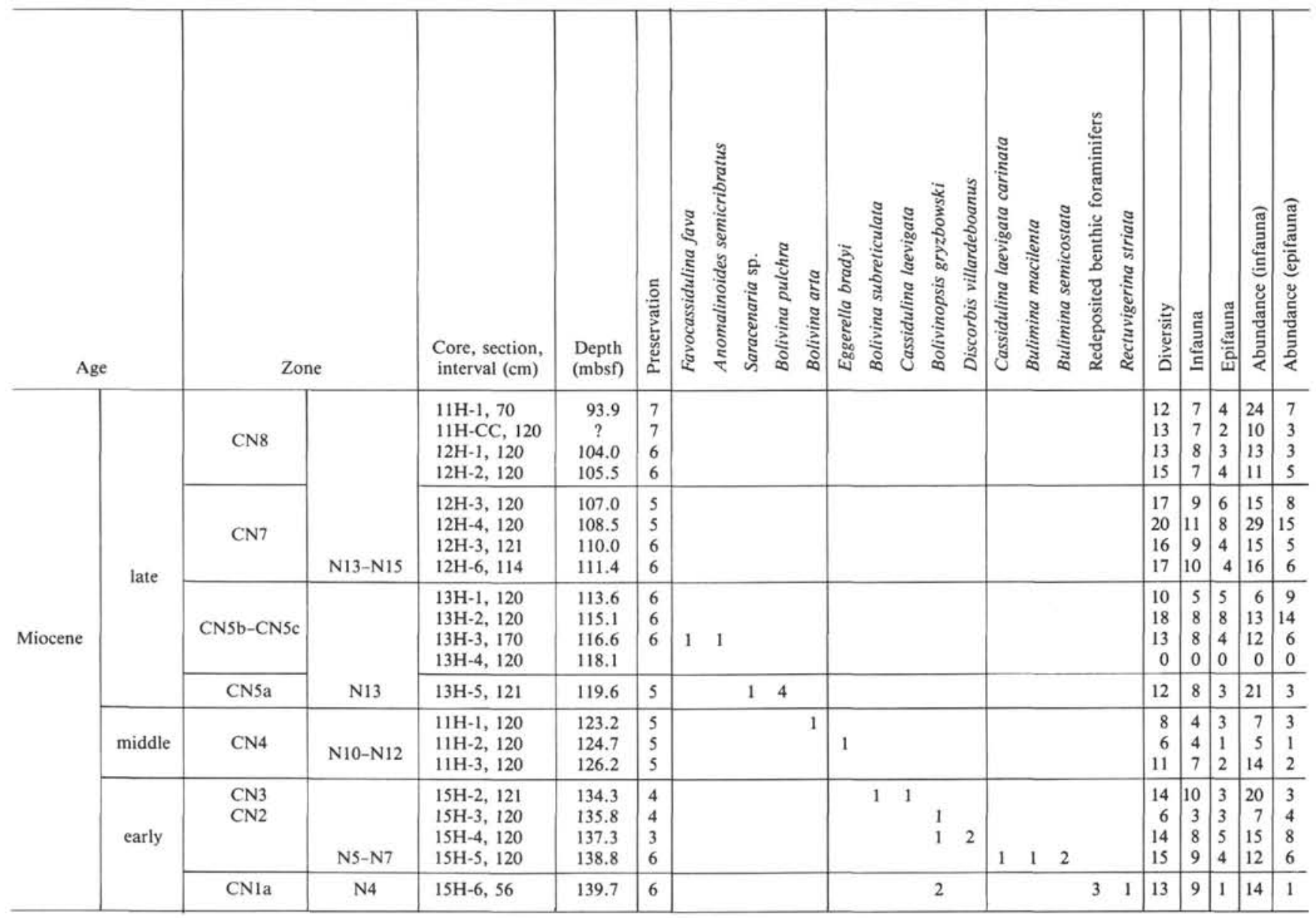

not found at this time (Fig. 11). Because uvigerinids are not found in IDW in the Mascarene Basin today and the indexes suggest oxic, but not well-oxygenated conditions, these faunas are called less oxic, western proto-IDW faunas. Together, the faunas at Sites 710 and 709 suggest that a well-oxygenated, lowsalinity, cold eastern Indian Ocean AABW-type bottom water underlying a moderately oxygenated deep water like eastern Indian Ocean IDW were present in the Mascarene Basin during the glacial at the end of the Miocene (Corliss, 1983; Peterson, 1984; Elmstrom and Kennett, 1985).

In summary, signals for the terminal Miocene glaciation include the development of modern eastern Indian Ocean-type IDW faunas at deep-water depths overlying eastern-IndianOcean-type AABW faunas at abyssal depths in both the Central Indian and Mascarene basins. Faunas indicate the presence of moderately well-saturated, warm, oxygenated deep waters, with elevated organic carbon contents in the underlying sediments, and cold, corrosive, oxic, low-salinity bottom waters.

\section{Pliocene}

In the early Pliocene a new abyssal fauna develops, although deep-water faunas reflect a clear partitioning between the Mascarene and Central Indian basins (Fig. 14). Deep-water faunal homogeneity is based on the presence of such forms as $F$. fava, P. murrhina, lagenids, and other miliolids that reflect the improvement in carbonate preservation at all sites (Table 3). The key to deep-water faunas in the Central Indian Basin, however, is the abundance of such uvigerinids as $U$. auberiana and some trifarinids, typical of IDW or CPDW today (Corliss, 1979; Pe- terson, 1984). Similarly, faunas at Site 709, lacking uvigerinids and $C$. wuellerstorfi but containing miliolids and $O$. umbona$t u s$, resemble those under IDW in the western Indian Ocean today (Corliss, 1979; Peterson, 1984). The Central Indian Basin faunas are called eastern proto-IDW faunas, whereas those at Site 709 are termed less fertile, western proto-IDW faunas because of the lack of $C$. wuellerstorfi.

The partitioning of deep-water faunas between the Mascarene and Central Indian basins in Zones CN10-CN11 suggests two possibilities:

1. Deep waters entering these basins had different source regions and/or different "aging" histories. Because western deep waters today experience a longer "aging" process because of their more circuitous routes through the western basins (Warren, 1981), this circulation route may have been initiated in the warmer, early Pliocene.

2. When the northern Indian Ocean ceased to be a source for intermediate and deep waters, deep waters in the Central Indian Basin were renewed by leakage from the southern Indian Basin, as happens today.

The presence of less oxygenated deep waters in the Mascarene Basin may be reflected in the deep-water benthic carbon isotope depletion between the late Miocene and early Pliocene (Shackleton et al., 1984) also registered in Hole 709B. Average early Pliocene benthic carbon isotope values, slightly depleted relative to those of latest Miocene Zone N17b (see Woodruff et al., this volume), indicate that an "aged" water mass is occupy- 


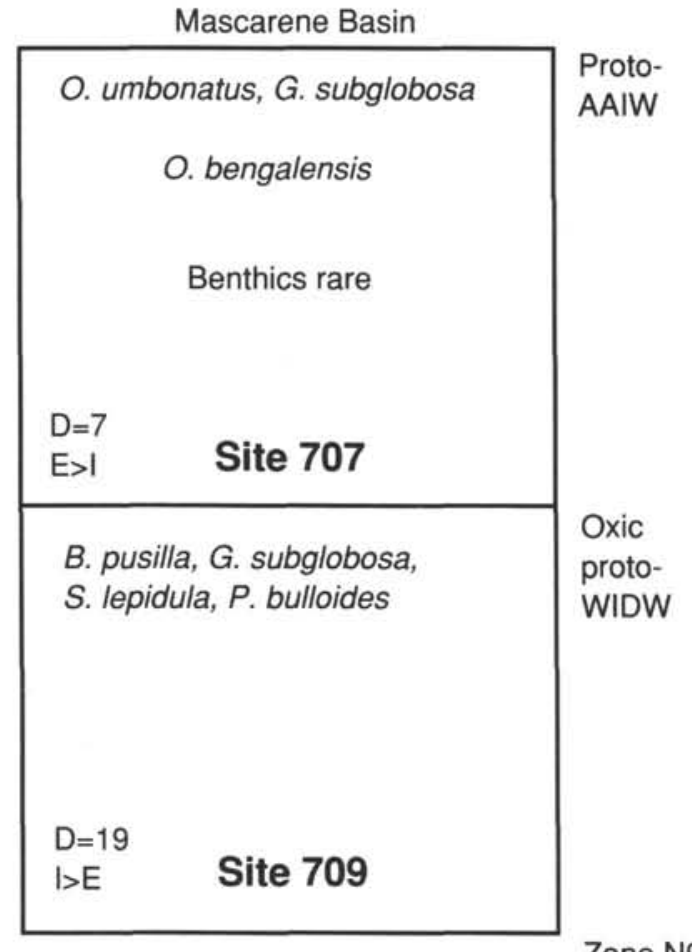

Time slice N9

Central Indian Basin

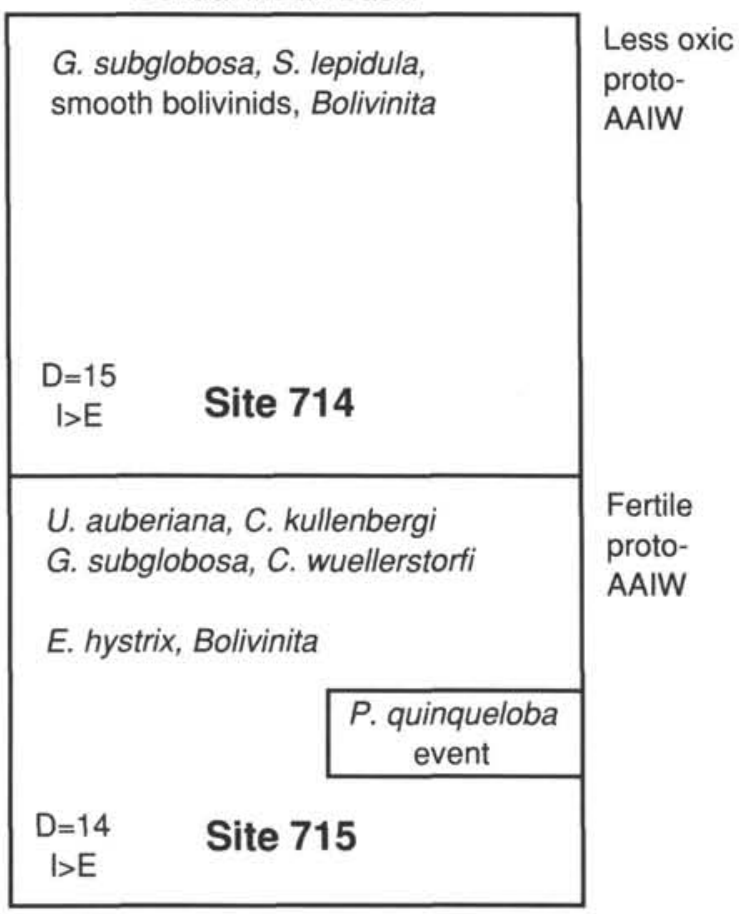

Figure 10. Benthic foraminifer index faunas of middle Miocene Zone N9 (= Zone CN4) from four sites in the western and central Indian Ocean. Indexes, listed at top, were most abundant or most consistently present. Index forms that occurred only in pulses or events are shown below. Total sample diversity and the relation of infaunal to epifaunal abundance are shown at bottom left of each box. The faunal name assigned to each index fauna is listed to the right of each box. Data from Tables 12-17. ing deep-water areas of the Mascarene Basin beginning in the early Pliocene. The $\sim 1 \%$ early Pliocene Atlantic-Pacific benthic carbon isotope gradient is similar to today's, suggesting that NADW formation was as active then as now (Shackleton et al., 1984). Thus, NADW production could have been responsible for "aged" deep waters in the northern Mascarene Basin at least by the early Pliocene.

Early Pliocene abyssal faunas at Site 710 in the Mascarene Basin were typified by $P$. quinqueloba and $M$. pompilioides, together with $O$. umbonatus and the gyroidinids, whereas such indexes for cold, low-salinity, and better oxygenated conditions as $N$. umbonifera and $E$. exiguua were absent. Although this fauna resembles the factor-species associated with warmer AABW in the eastern Indian Ocean today, the presence of the gyroidinids also suggests that bottom waters were less oxygen rich at this time (Fig. 14). This faunal type is termed the less oxic, warmer proto-AABW fauna. In summary, water masses similar to those in the modern eastern Indian Ocean basins occupied deep and abyssal depths in the Mascarene Basin in the early Pliocene.

By Zone $\mathrm{CN} 12$, the interstratification of more oxygen-rich deep water with lower oxygen intermediate and abyssal waters is suggested by the benthic index faunas (Fig. 16). Faunas at Site 710 contain indexes typical of eastern Indian Bottom Water, a lagenid-M. pompilioides-G. subglobosa-F. fava fauna with increasing numbers of uvigerinids. This water type is characterized by higher temperature, higher salinity, and lower dissolved oxygen contents than AABW (Corliss, 1979), and the fauna is here called an eastern proto-IBW fauna. Uvigerinids, which flourish in IDW, CPDW, and IBW in the Central Indian Basin, indicate increased accumulation of organic carbon, presumably resulting from the higher fertility of the southern source region. Lack of bolivinids and buliminids indicate well-oxygenated bottom waters and upper pore waters.

Deep-water faunas at Site 709 resemble those under AABW in the modern eastern Indian Ocean (Corliss, 1979). Index species include $N$. umbonifera and $G$. neosoldanii, whereas the lagenids, miliolids, and $F$. fava reflect improved carbonate preservation. This fauna appears intermediate between those factorfaunas in the eastern Indian Ocean today (Corliss, 1979) and those that underlie western Indian deep waters (Corliss, 1983). This fauna may represent the transition between water masses of eastern affinities and the development of typical western Indian IDW, which must then have occurred after late Pliocene Zone N21 time. This fauna is called, therefore, the transitional western Idw fauna.

Deep-water faunas at Site 238 in the Central Indian Basin are typical of those at equivalent depths under IDW today. Although the miliolids may reflect improved preservation of carbonates (Table 2), the occurrence of the uvigerinid-miliolid index fauna in samples lacking $N$. umbonifera or E. exiguua indicates the presence of an "aged," possibly less corrosive, deep water like the modern IDW of the Central Indian Basin (Bremer and Lohmann, 1982; Peterson, 1984). This fauna, therefore, is called the eastern proto-IDW fauna.

\section{CONCLUSIONS}

A quantitative census of benthic foraminifers from 20 sites in the Mascarene, Arabian, Central Indian, and Wharton basins and the Bay of Bengal produced index faunas indicative of oceanographic and water-mass reorganization from the late Oligocene to the late Pliocene in the tropical-subtropical Indian Ocean.

Indexes associated with modern bottom waters can be used to trace the history of abyssal areas of the Mascarene Basin. These include $N$. umbonifera, E. exiguua, $M$. pompilioides, and $P$. quinqueloba. A distinct bottom-water fauna cannot be 
Table 13. Ranges of benthic foraminifers through the early to middle Miocene in Hole 715A.

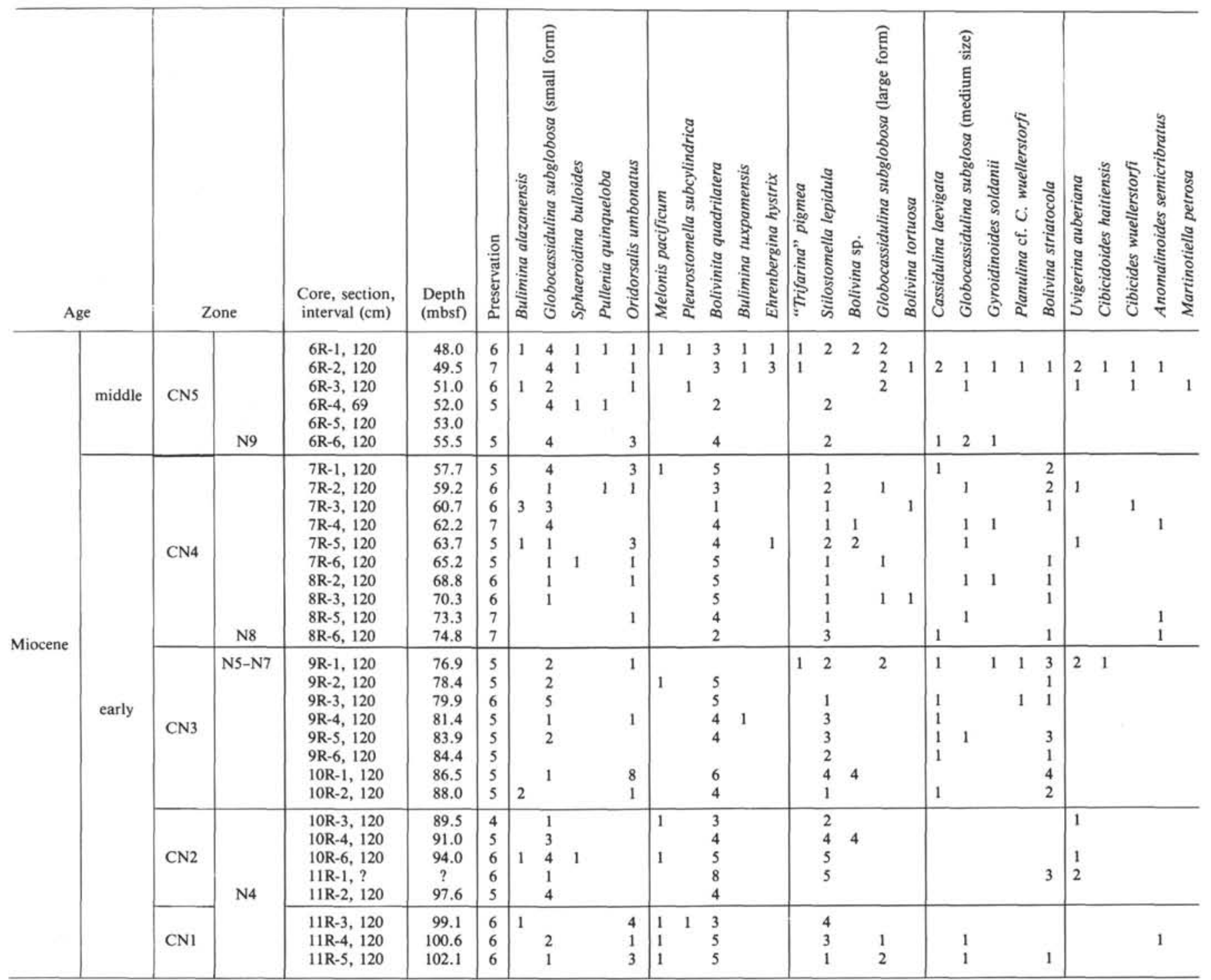

Note: Explanation as in Table 3.

identified in the late Oligocene and early Miocene when deepwater indexes associated with well-oxygenated waters, such as C. kullenbergi, were ubiquitous in the Mascarene Basin.

Infaunal indexes can be used to interpret conditions within the sediment. Indicative of organic-carbon-rich sediments are the uvigerinids, trifarinids, rectuvigerinids, high ratios of infauna:epifauna, and high benthic foraminifer diversity. Buliminid and bolivinid abundance is associated with the development of low-oxygen conditions. Low biomass of largely rotaloid benthic foraminifers is associated with well-oxygenated, low-fertility conditions under waters similar to modern AAIW.

Evidence of the formation of intermediate and deep waters within the Indian Ocean beginning in Zone CP18 (Zone P21) of the late Oligocene, and continuing from early to later Miocene, derives not only from the fossils but also from the redeposition patterns. Materials redeposited to deep and abyssal areas come from intermediate, not shallow water depths. One explanation for this pattern is that the materials derive from a vigorously sinking intermediate water mass. Redeposition of northernsource intermediate water fossils into the abyssal Mascarene Basin indicates north-south redeposition of material from intermediate depths. A northern source of sinking, well-oxygenated, sa- line waters based on carbon isotope data (Woodruff and Savin, 1989 ) is also indicated by the fossil data.

Faunal criteria for recognizing the source region of sinking intermediate- and deep-water masses include development of (1) vertical faunal homogeneity from intermediate through abyssal areas, and (2) index faunas for well-oxygenated water masses and aerated conditions in the sediments from intermediate into abyssal areas.

Infaunal indexes indicate the evolution of conditions underlying intermediate waters in the northern Indian Ocean:

1. Less oxygenated conditions in the sediment in the northern Indian Ocean beginning in late Oligocene Zone CP18;

2. Oxygen-rich, "new" waters and aerated conditions in the sediment from the latest Oligocene through most of the early Miocene after Zone $\mathrm{CN1}$ and into the early middle Miocene; these waters may have been more fertile than their late Neogene analogs;

3. Organic-carbon-rich, less oxygenated bottom sediments and water masses early in late Miocene Zone CN9;

4. Beginning in early Pliocene Zones CN10-CN11, oxygenrich, probably low-nutrient conditions in the northern Masca- 
Table 13 (continued).

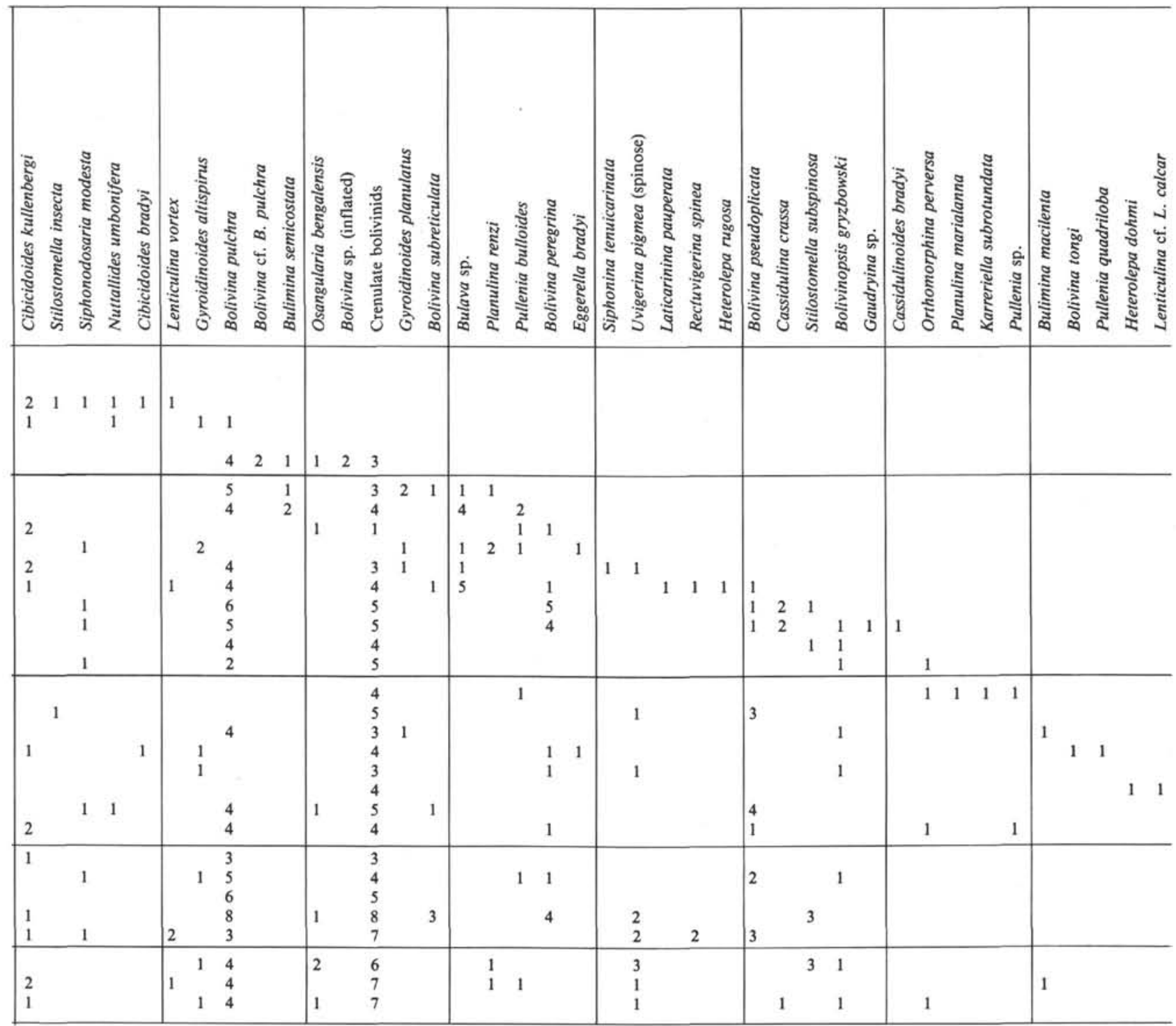

rene Basin, but fertile, oxygen-depleted sediments and water masses to the north in the Arabian Sea and under the southern Indian upwelling zone.

Benthic signals for the late Miocene glaciation in the northern Indian Ocean include (1) increased numbers of bottom-water indexes in abyssal areas and updepth migration of bottom water indexes; (2) increased numbers of bottom-water indexes at intermediate depth sites; (3) increased numbers of spinocostate uvigerinids and miliolids at intermediate- and deep-water sites; and (4) decreased numbers of bolivinids and buliminids at intermediate depths.

Water-mass stratification during the latest Miocene and earliest Pliocene glacial episodes reflected the expansion of well-oxygenated intermediate waters throughout the northern Mascarene Basin and southern Arabian Sea. This means that the less well-oxygenated waters and conditions prevalent at the time of the Epoch 6 carbon shift were eventually replaced by well-oxygenated conditions at intermediate depths. A well-oxygenated intermediate water spread not only through the Mascarene Basin, but as far north as the southern Arabian Sea during this glacial episode. This water mass was more fertile than modern AAIW.

By the end of the Miocene, deep- and bottom-water faunas resembled their modern counterparts. Deep-water masses first resembled eastern IDW in both the Mascarene and Central Indian basins before the glacial episode in late Miocene Zone CN9. When the northern Indian Ocean ceased to be a region of deep-water formation, the "aged," less oxygen-rich deep waters of both northern basins probably came from the south. By the early Pliocene, however, proto-IDW-type faunas were sequestered in the Central Indian Basin, presumably as the result of deep-water inflow from the southern Indian Basin, as occurs today.

Early Pliocene faunas of the Mascarene Basin indicate a different southern influence: a fauna similar to those under modern AAIW existed at intermediate depths, while a warmer, moderately well-oxygenated AABW type fauna expanded throughout the northern Mascarene Basin from abyssal to deep-water depths. Updepth expansion of abyssal indexes implies either decreased deep-water or increased bottom-water circulation through the Mascarene Basin in the warmer part of the early Pliocene. 
Table 13 (continued).

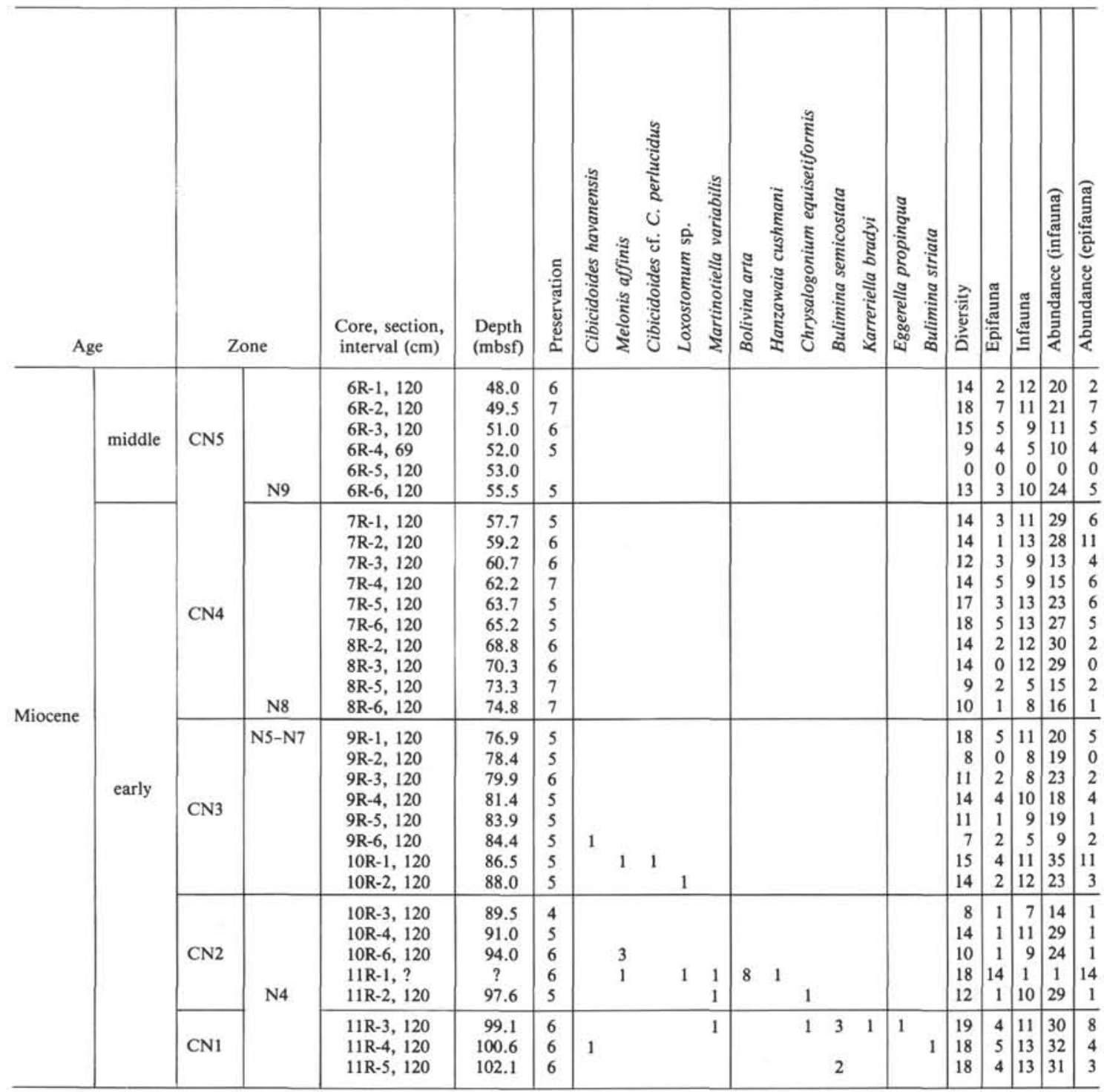

By late Pliocene Zone CN12, index faunas in the Mascarene Basin suggest the stratification of a well-oxygenated deep water between intermediate and abyssal water masses that were more organic carbon rich, but lower in oxygen. Deep and abyssal faunas resemble those from the eastern basins today. The modern western basin faunas had not developed in the Mascarene Basin by Zone $\mathrm{CN} 12$ time.

\section{ACKNOWLEDGMENTS}

I would like to thank J. Backman, the Ocean Drilling Program, and USSAC for inviting me to participate on Leg 115. Support provided for post-cruise studies by USSAC and W. A. Berggren, Woods Hole, is gratefully acknowledged. Additional samples were kindly provided by C. Mato from the ODP Core Repository in College Station. I. Premoli Silva, University of Milan, kindly offered the use of the scanning microscope laboratory, and the photographs were taken by A. Rizzi, CNR of Milano. Special thanks go to B. Corliss for reviewing this paper, and to F. Woodruff, whose relentless pursuit of clarity greatly improved the manuscript.

\section{REFERENCES}

Archer, D., Emerson, S., and Smith, C., 1989. Direct measurement of the diffusive sublayer at the deep sea floor using oxygen microelectrodes. Nature, 340:623-626.

Backman, J., Duncan, R., et al., 1988. Proc. ODP, Init. Repts., 115: College Station, TX (Ocean Drilling Program).

Banse, K., 1968. Hydrography of the Arabian Sea shelf of India and Pakistan and effects of demersal fishes. Deep-Sea Res., 15:45-79.

Boersma, A., 1984. Handbook of Common Tertiary Uvigerina: Stony Point, NY (Microclimates Press).

1985a. Oligocene benthic foraminifers from North Atlantic sites: benthic foraminifers as water-mass indexes in the North and South Atlantic. In Bougalt, H., Cande, S. C., et al., Init. Repts. DSDP, 82: Washington (U.S. Govt. Printing Office), 611-627. ,1985b. Pliocene planktonic and benthic foraminifers from the southeastern Atlantic Angola margin: Leg 75, Site 532, Deep Sea Drilling Project. In Hay, W. W., Sibuet, J.-C., et al., Init. Repts. DSDP, 75, Pt. 2: Washington (U.S. Govt. Printing Office), 657-670. $1985 \mathrm{c}$. Biostratigraphy and biogeography of Tertiary bathyal benthic foraminifers: Tasman Sea, Coral Sea, and on the Chatham Rise (Deep Sea Drilling Project, Leg 90). In Kennett, J. P., von der Borch, C. C., et al., Init. Repts. DSDP, 90, Pt. 2: Washington (U.S. Govt. Printing Office), 961-1037. 
Boersma, A., and Shackleton, N., 1977. Oxygen and carbon isotope record through the Oligocene, DSDP Site 366, equatorial Atlantic. In Lancelot, Y., Seibold, E., et al., Init. Repts. DSDP, 41: Washington (U.S. Govt. Printing Office), 957-962.

Boltovskoy, E., 1977. Neogene deep water benthonic foraminifera of the Indian Ocean. In Heirtzler, J. R., Bolli, H. M., Davies, T. A., Saunders, J. B., and Sclater, J. G. (Eds.), Indian Ocean Geology and Biostratigraphy: Washington (American Geophysical Union), 599-616.

Bremer, M., and Lohmann, G., 1982. Evidence for primary control of the distribution of certain Atlantic Ocean benthonic foraminifera by degree of carbonate saturation. Deep-Sea Res., 29:987-998.

Brun, L., Chierici, M., and Meijer, M., 1982. Evolution and morphological variations of the principal species of Bolivinitidae in the Tertiary of the Gulf of Guinea. Geol. Mediterr., 11:13-57.

Burke, S. C., 1981. Recent benthic foraminifera of the Ontong-Java Plateau., J. Foraminiferal Res., 11:1-19.

Cita, M., and Zocchi, M., 1978. Distribution patterns of benthic foraminifera on the floor of the Mediterranean Sea. Oceanol. Acta, 1: 445-462.

Clarke, M., and Wright, R., 1984. Paleogene abyssal foraminifers from the Cape and Angola Basins, South Atlantic Ocean. In Hsü, K. J., LaBrecque, J. L., et al., Init. Repts. DSDP, 73: Washington (U.S. Govt. Printing Office), 459-480.

Corliss, B., 1979. Recent deep-sea benthonic foraminiferal distributions in the southeast Indian Ocean: inferred bottom-water routes and ecological implications. Mar. Geol., 31:115-138.

1983. Distribution of Holocene deep sea benthonic foraminifera in the southwest Indian Ocean. Deep-Sea Res., 30:95-117.

Corliss,- B., and Chen, T., 1988. Morphotype patterns of Norwegian Sea deep-sea benthic foraminifera and ecological implications. Geology, 16:716-719.

Corliss, B., and Honjo, S., 1980. Dissolution of deep-sea benthonic foraminifera. Micropaleontology, 27:356-378.

Douglas, R., 1981. Paleoecology of continental margin basins: a modern case history from the borderland of Southern California. Depositional Systems of Active Continental Margin Basins, SEPM, Pacific Section, Short Course, 121-156.

Elmstrom, K., and Kennett, J. P., 1985. Late Neogene paleoceanographic evolution of Site 590: southwest Pacific. In Kennett, J. P., von der Borch, C. C., et al., Init. Repts. DSDP, 90: Washington (U.S. Govt. Printing Office), 1361-1383.

Gary, A., 1985. A preliminary study of the relationship between test morphology and bathymetry in Recent Bolivina albatrossi Cushman, northwestern Gulf of Mexico. Trans. Gulf Coast Assoc. Geol. Soc., 35:381-386.

Hendrix, W., 1958. Foraminiferal shell form, a key to sedimentary environment. J. Paleontol., 32:649-659.

Heirtzler, J. R., Bolli, H. M., Davies, T. A., Saunders, J. B., and Sclater, J. G., 1977. Indian Ocean Geology and Biostratigraphy: Washington (American Geophysical Union).

Hodell, D., Williams, D., and Kennett, J. P., 1985. Late Pliocene reorganization of deep vertical water-mass structure in the western South Atlantic: faunal and isotopic evidence. Geol. Soc. Am. Bull., 96: 495-505.

Jahnke, R., Heggio, D., Emerson, S., and Grundmaris, V., 1982. Pore water of the central Pacific Ocean: nutrient results. Earth Planet. Sci. Lett., 61:233-256.

Johnson, D., 1985. Abyssal teleconnections II. Initiation of Antarctic Bottom Water flow in the southwestern Atlantic. In Hsü, K., and Weissert, H. (Eds.), South Atlantic Paleoceanography: Cambridge (Cambridge Univ. Press), 283-325.

Keigwin, L., and Corliss, B., 1986. Stable isotopes in late middle Eocene to Oligocene foraminifera. Geol. Soc. Am. Bull., 97:335-345.

Leutenegger, S., and Hansen, H., 1979. Ultrastructural and radiotracer studies of pore function in foraminifera. Mar. Biol., 54:11-16.

Lutze, G., 1977. Neogene benthonic foraminifera from Site 369, Leg 41, Deep Sea Drilling Project. In Lancelot, Y., Seibold, E., et al., Init. Repts. DSDP, 41: Washington (U.S. Govt. Printing Office), 659666.

Lutze, G., and Coulbourn, W., 1984. Recent benthic foraminifera from the continental margin of northwest Africa: community structure and distribution patterns. Mar. Micropaleontol., 8:361-401.

Lohmann, G., 1978. Abyssal benthonic foraminifera as hydrographic indexes in the western South Atlantic Ocean. J. Foraminiferal Res., $8: 6-34$.
Mead, G., 1985. Recent benthic foraminifera in the Polar Front region of the southwest Atlantic. Micropaleontology, 31:21-248.

Miller, K., and Curry, W., 1985. Late Paleogene (Eocene to Oligocene) benthic foraminiferal oceanography of the Goban Spur region, Deep Sea Drilling Project Leg 80. In de Graciansky, P. C., Poag, C. W., et al., Init. Repts. DSDP, 80, Pt. 1: Washington (U.S. Govt. Printing Office), 505-538.

Miller, K., and Lohmann, G., 1982. Environmental distribution of Recent benthic foraminifera on the Northeast United States continental slope. Bull. Geol. Soc. Am., 93:200-206.

Murray, J., 1973. Distribution and Ecology of Recent Foraminifera: Baltimore, MD (Johns Hopkins Press).

Oberhänsli, H., 1986. Latest Cretaceous-early Neogene oxygen and carbon isotopic record at DSDP sites in the Indian Ocean. Mar. Micropaleontol., 10:91-115.

Oberhänsli, H., Grunig, A., and Herb, R., 1983. Oxygen and carbon isotope study in the late Eocene sediments of Possagno (northern Italy). Riv. Ital. Paleontol. Strat., 89:377-394.

Peterson, L. C., 1984. Recent abyssal benthic foraminiferal biofacies of the eastern equatorial Indian Ocean. Mar. Micropaleontol., 8:479519.

Phleger, F., and Soutar, A., 1973. Production of benthic foraminifera in three east Pacific oxygen minima. Micropaleontol., 19:110-115.

Poag, W., 1981. Ecologic Atlas of Benthic Foraminifera of the Gulf of Mexico: Stroudsberg, PA (Hutchinson and Ross Publ.).

Poag, W., and Low, D., 1984. Environmental trends among Neogene benthic foraminifers at Deep Sea Drilling Project Site 548, Irish Continental Margin. In de Graciansky, P. C., Poag, C. W., et al., Init. Repts. DSDP, 80, Pt. 1: Washington (U.S. Govt. Printing Office), 489-503.

Reid, J., Nowlin, W., and Patzert, W., 1977. On the characteristics and circulation of the southwestern Atlantic Ocean. J. Phys. Oceanogr., 77:62-90.

Ross, C., and Kennett, J. P., 1983. Late Quaternary paleoceanography as recorded by benthonic foraminifera in Strait of Sicily sediment sequences. Mar. Micropaleontol., 8:315-336.

Saunders, J., Bernoulli, D., Muller-Merz, E., Oberhänsli, H., PerchNielsen, K., Riedel, W., Sanfilipo, A., and Torrini, R., 1985. Stratigraphy of the late middle Eocene to early Oligocene in the Bath Cliff section, Barbados, West Indies. Micropaleontology, 30:390-425.

Schnitker, D., 1974. West Atlantic abyssal circulation during the past 120,000 years. Nature, 248:385-387.

1979. Cenozoic deep water benthic foraminifers, Bay of Biscay. In Montadert, L., Roberts, D. G., et al., Init. Repts. DSDP, 48: Washington (U.S. Govt. Printing Office), $377-413$.

Seiglie, G., 1968. Foraminiferal assemblages as indexes of organic carbon content in sediments or of water pollution. AAPG Bull., 52: 2231-2241.

Shackleton, N., Hall, M., and Boersma, A., 1984. Oxygen and carbon isotope data from Leg 74 foraminifers. In Moore, T. C., Jr., Rabinowitz, P. D., et al., Init. Repts DSDP., 74: Washington (U.S. Govt. Printing Office) 599-612.

Shackleton, N. J., and Kennett, J. P., 1975. Paleotemperature history of the Cenozoic and the initiation of Antarctic glaciation: oxygen and carbon isotope analyses in DSDP Sites 277, 279, and 281. In Kennett, J. P., Houtz, R. E., et al., Init. Repts. DSDP, 29: Washington (U.S. Govt. Printing Office), 743-755.

Thomas, E., 1985. Late Eocene to Recent deep-sea benthic foraminifers from the central equatorial Pacific Ocean. In Mayer, L., Theyer, F., Thomas, E., et al., Init. Repts. DSDP, 85: Washington (U.S. Govt. Printing Office), 655-694.

1986. Early to middle Miocene benthic foraminiferal faunas from DSDP Sites 608 and 610, North Atlantic. In Summerhayes, C. P., and Shackleton, N. J. (Eds.), North Atlantic Palaeoceanography. Spec. Publ., Geol. Soc. (London), 21:205-218.

Tjalsma, L., 1983. Eocene to Miocene benthic foraminifers from Deep Sea Drilling Project Site 516, Rio Grande Rise, South Atlantic. In Barker, P. F., Carlson, R. L., Johnson, D. A., et al. Init. Repts. DSDP, 72: Washington (U.S. Govt. Printing Office), 731-755.

Tjalsma, L., and Lohmann, G., 1983. Paleocene-Eocene bathyal and abyssal benthic foraminifera from the Atlantic Ocean. Spec. Publ., Micropaleontol., 4:1-90.

Vincent, E., Killingley, J., and Berger, W., 1980. The magnetic epoch-6 carbon shift: a change in the oceans $\mathrm{C} 13 / \mathrm{C} 12$ ratio 6.2 million years ago. Mar. Micropaleontol., 5:185-203. 
, 1985. Miocene oxygen and carbon isotope stratigraphy of the tropical Indian Ocean. In Kennett, J. P. (Ed.), The Miocene Ocean. Mem. Geol. Soc. Am., 163:103-130.

Warren, B., 1981. Transindian hydrographic section at Lat. $18^{\circ} \mathrm{S}$ : property distributions and circulation in the South Indian Ocean. DeepSea Res., 28A:759-788.

Woodruff, F., 1985. Changes in Miocene deep-sea benthic foraminifera distribution in the Pacific Ocean: relationship to paleoceanography. In Kennett, J. P. (Ed.), The Miocene Ocean. Mem. Geo. Soc. Am., 163:131-176.

Woodruff, F., and Douglas, R., 1981. Response of deep-sea benthic foraminifera to Miocene paleoclimatic events, DSDP Site 289. Mar. Micropaleontol., 6:617-632.
Woodruff, F., and Savin, S., 1989. Miocene deepwater oceanography. Paleoceanography, 4:87-140.

Wyrtki, K., 1973. Physical oceanography of the Indian Ocean. In Zeitzschel, B. (Ed.), The Biology of the Indian Ocean: Berlin-Heidelberg-New York (Springer-Verlag), 18-36.

Date of initial receipt: 1 June 1989

Date of acceptance: 15 January 1990

Ms 115B-146 
Mascarene Basin

\begin{tabular}{|c|c|}
\hline \multicolumn{2}{|c|}{$\begin{array}{l}\text { U. auberiana, C. wuellerstorfi, } \\
\text { G. subglobosa small, lagenids }\end{array}$} \\
\hline & $\begin{array}{l}\text { Uvigerinids } \\
\text { R. spinea } \\
\text { E. exiguua }\end{array}$ \\
\hline \multicolumn{2}{|c|}{ Site 707} \\
\hline \multicolumn{2}{|c|}{ G. subglobosa, O. umbonatus } \\
\hline \multicolumn{2}{|c|}{$\begin{array}{l}\text { Uvigerinids, U. proboscidea, } \\
N \text {. umbonifera }\end{array}$} \\
\hline & $\begin{array}{l}\text { Uvigerinids } \\
\text { Pyrgo }\end{array}$ \\
\hline $\begin{array}{l}D=25 \\
I>E\end{array}$ & \\
\hline
\end{tabular}

Arabian Sea

B. alazanensis, uvigerinids,

C. kullenbergi, S. lepidula,

G. subglobosa, O. umbonatus,

$M$. affinis, bolivinids

Uvigerinids Loss of crenulate bolivinids

E. exiguua

$\mathrm{D}=45$

N. umbonifera

$1 \gg \mathrm{E}$

\section{Site 219}

Proto-

AAIW
Central Indian Basin

$U$. auberiana-O. umbonatus, lagenids, crenulate bolivinids, C. kullenbergi, B. alazanensis

Loss of all bolivinids

N. umbonifera

$D=29$

$1>E$

\section{Site 713}

Proto-

IDW
Oxic

proto-

NIIW

Time slice

N17

Mascarene Basin

E. exiguua-N. umbonifera,

O. umbonatus, $C$. wuellerstorfi

Figure 11. Benthic foraminifer index faunas of late Miocene Zone N17 (= Zone CN9) from five sites in the western and central Indian Ocean. Indexes, listed at top, were most abundant or most consistently present. Index forms that occurred only in pulses or events are shown below. Total sample diversity and the relation of infaunal to epifaunal abundance are shown at bottom left of each box. The faunal name assigned to each index fauna is listed to the right of each box. Data from Tables 12-17. 


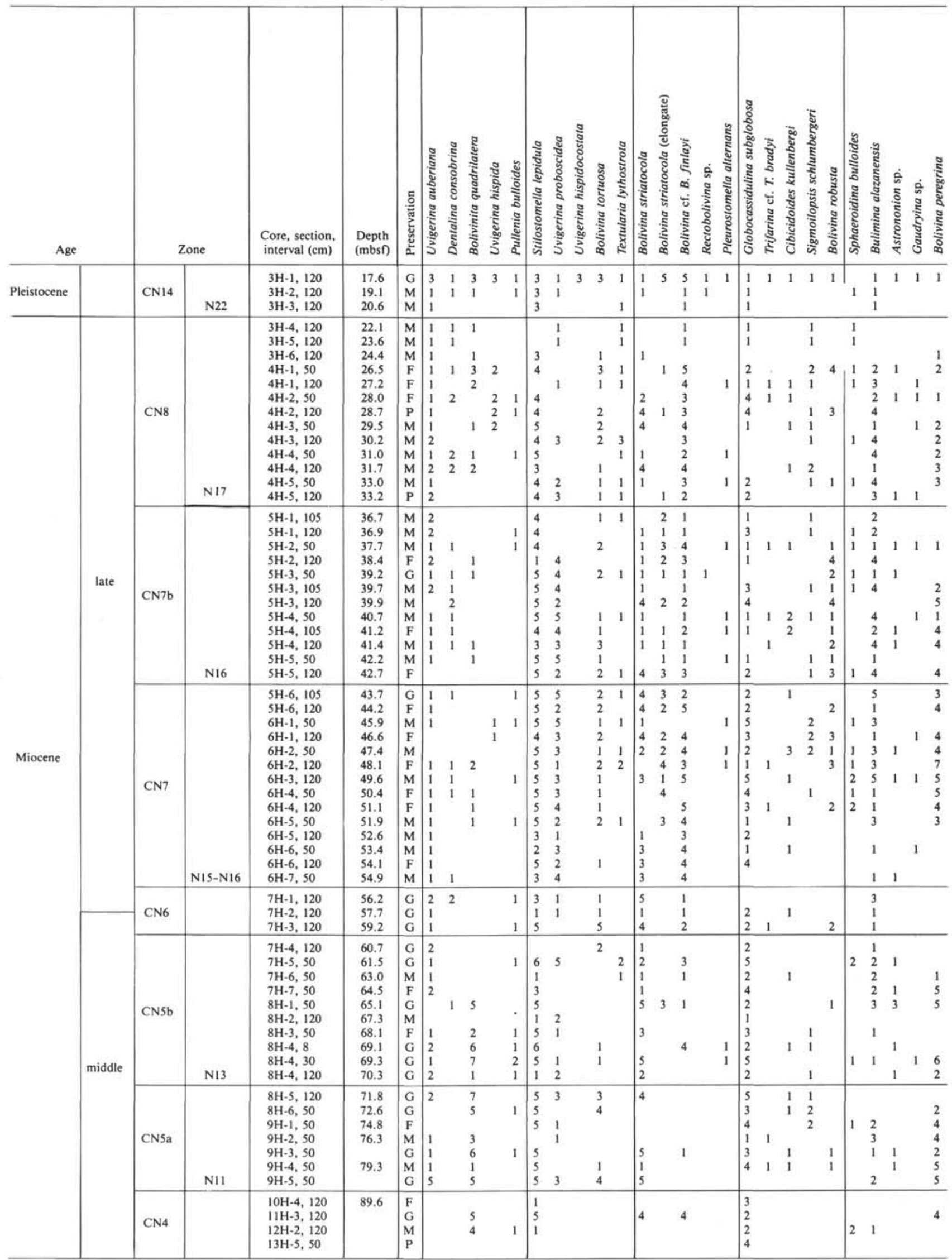

Note: Explanation as in Table 3. 
Table 14 (continued).

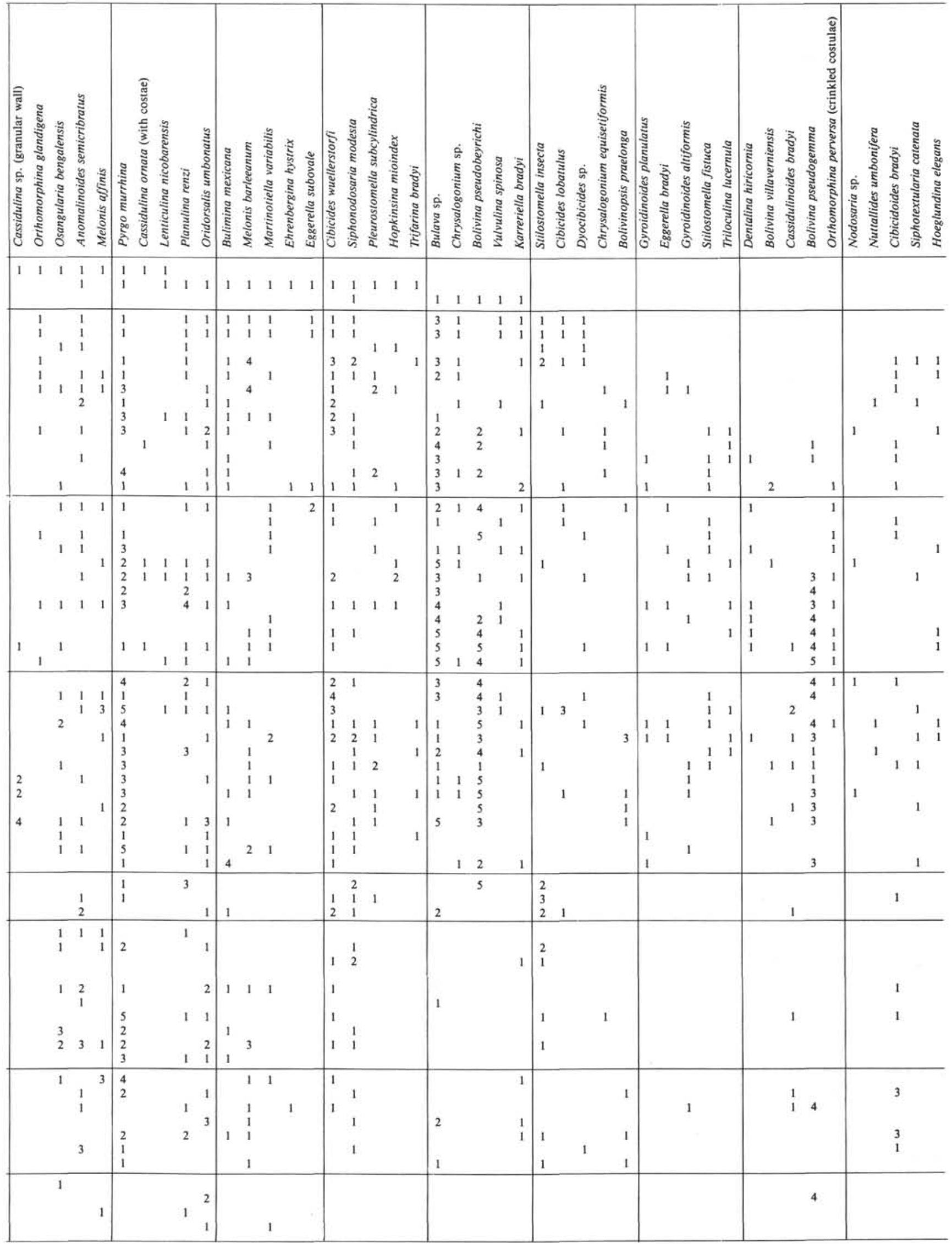


Table 14 (continued).

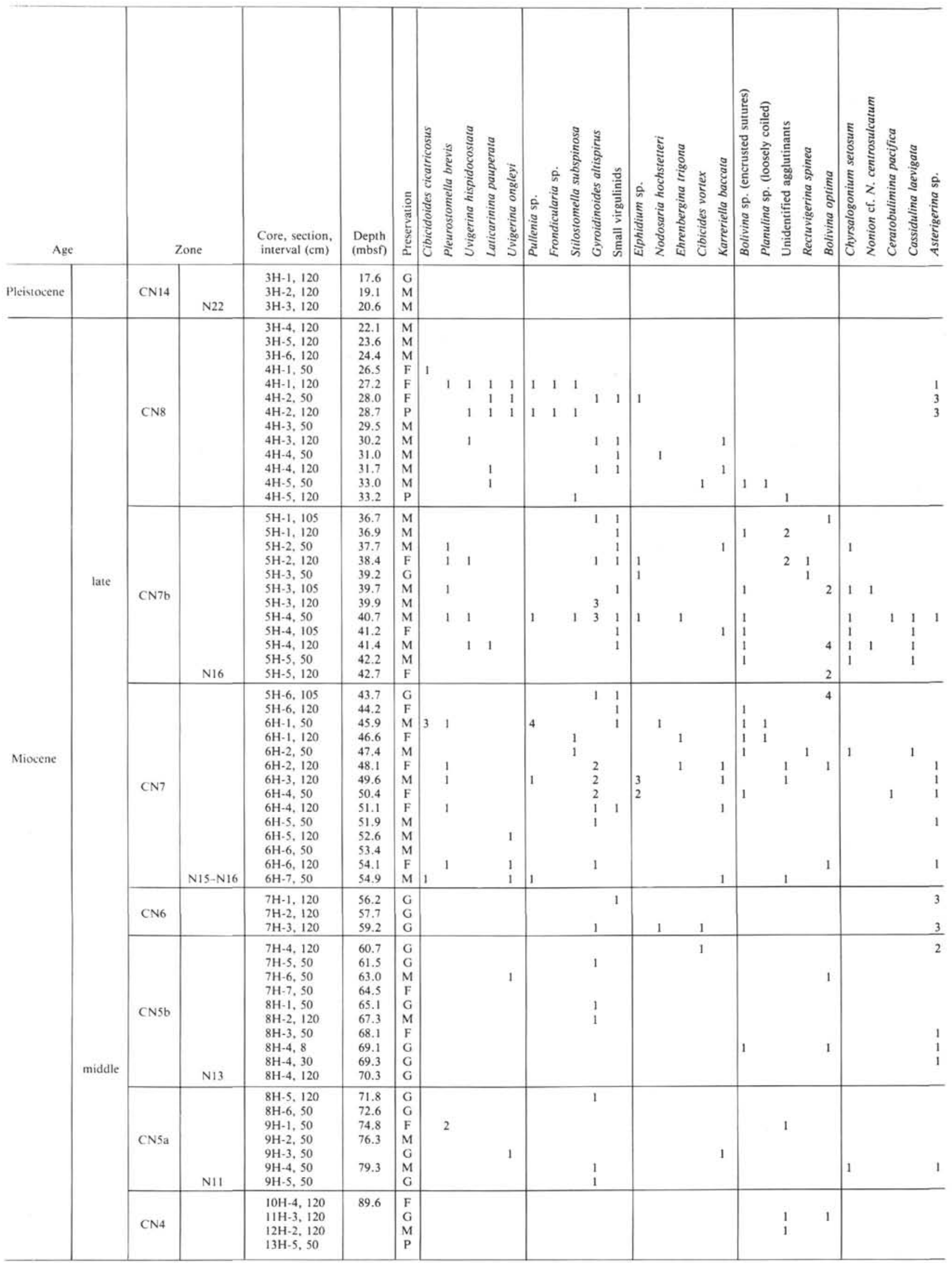


Table 14 (continued).

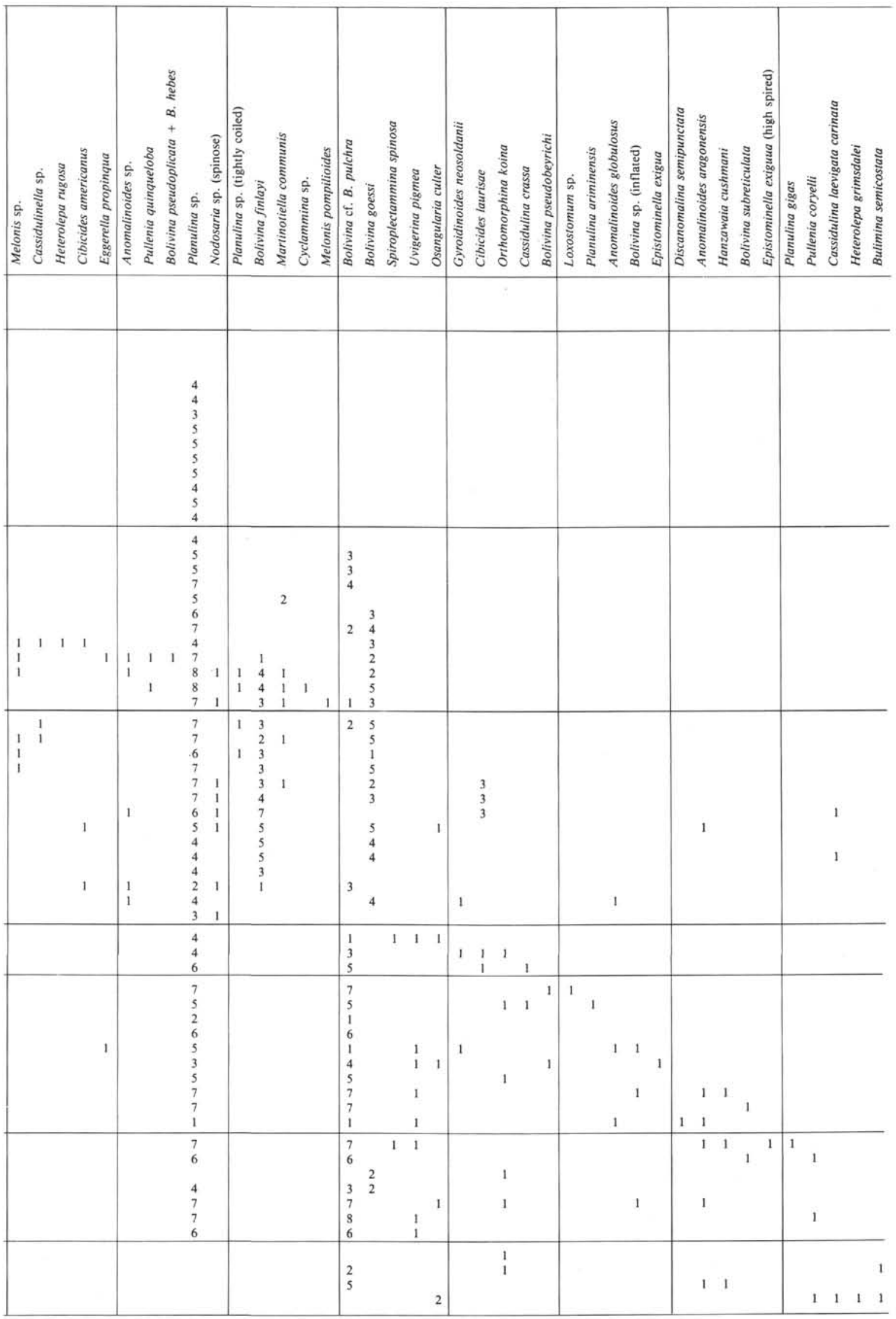


Table 14 (continued).

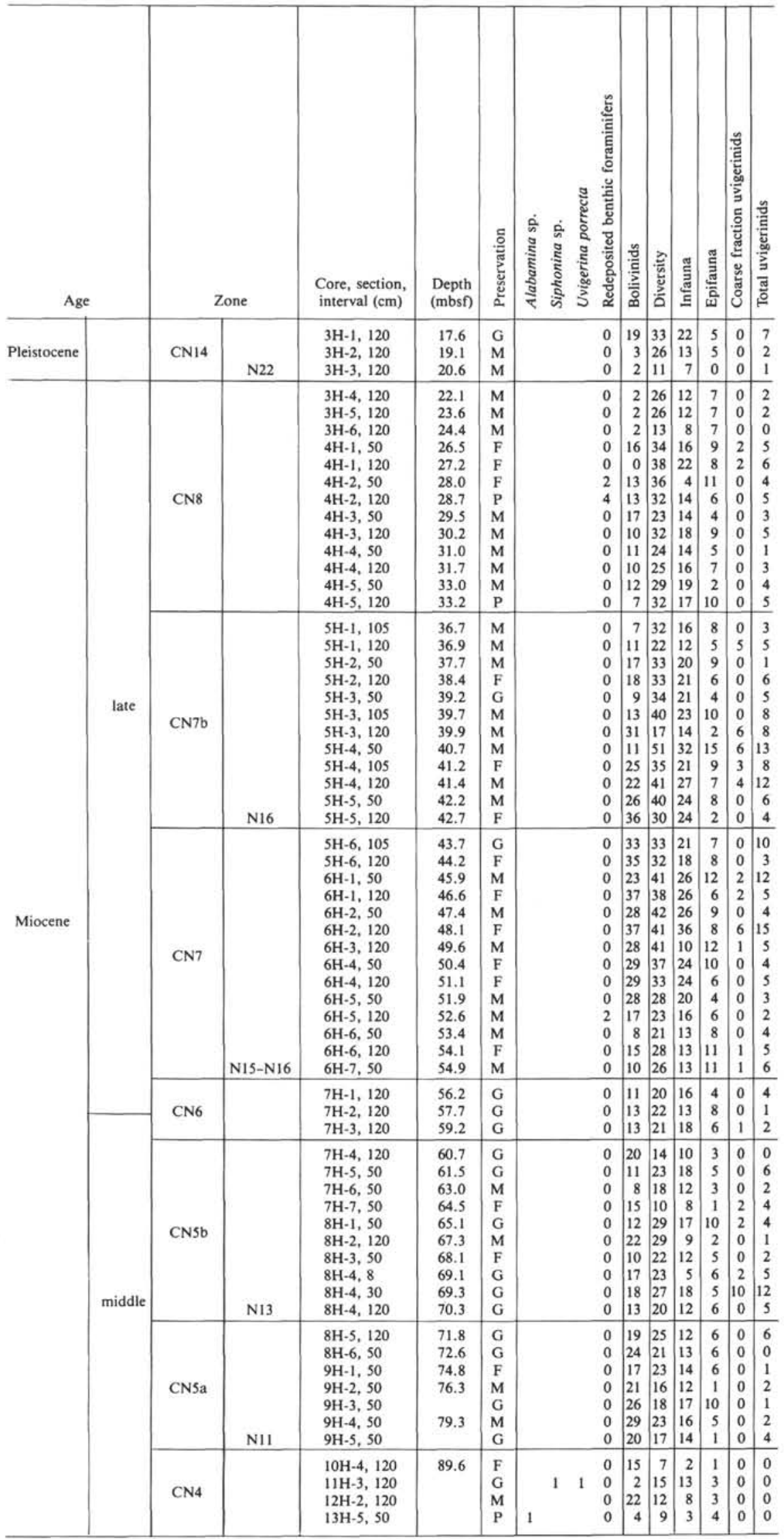




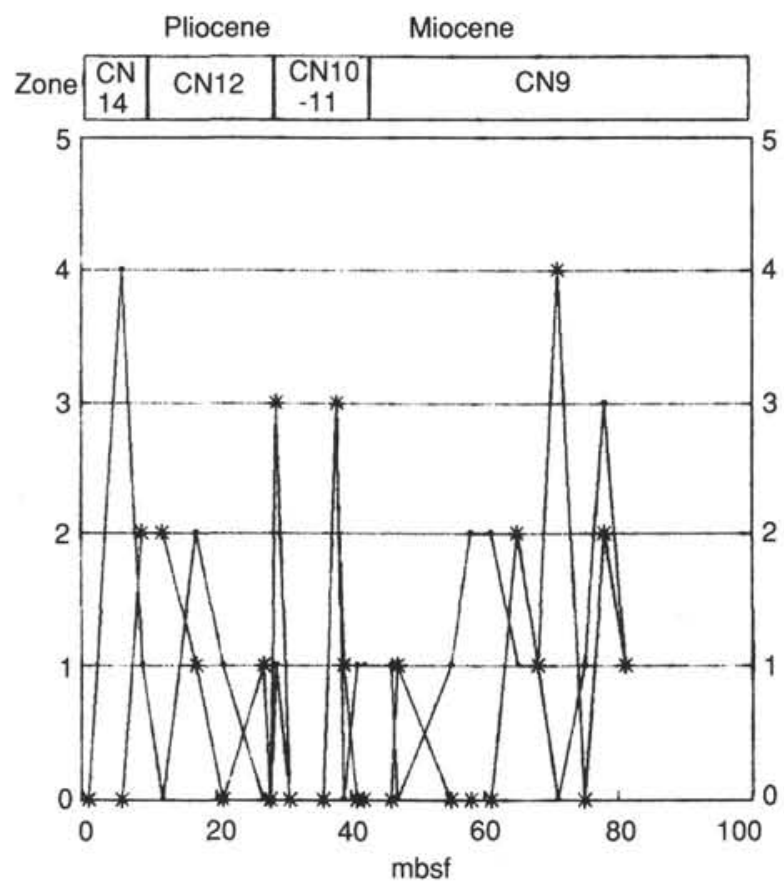

-U. auberiana $\quad *$ G. subglobosa
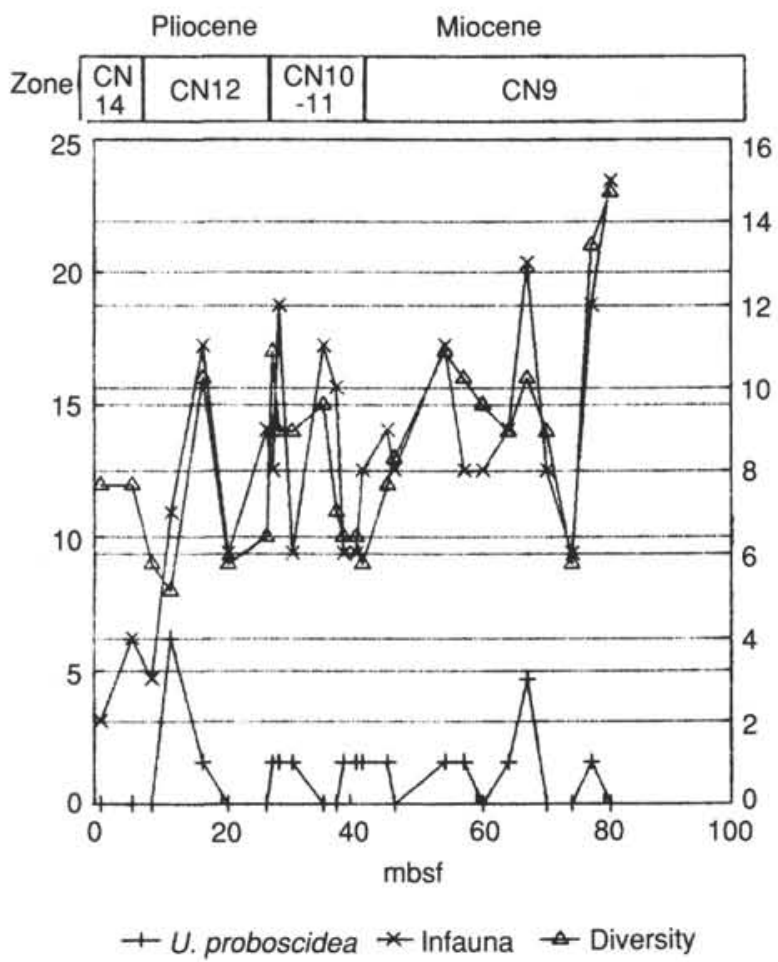

Figure 12. Relative abundances of most common benthic foraminifers from the late Miocene through the Pliocene at Site 707. Species include Uvigerina auberiana, Globocassidulina subglobosa, and Uvigerina proboscidea. Total infaunal number and total benthic foraminifer diversity in each sample are also plotted. As at other sites, there is generally an inverse relation between abundances of $U$. auberiana and $G$. subglobosa. Data from Table 19. Zonation from Backman, Duncan, et al. (1988). 
Table 15. Ranges of benthic foraminifers through the early-middle Miocene in Hole 709A.

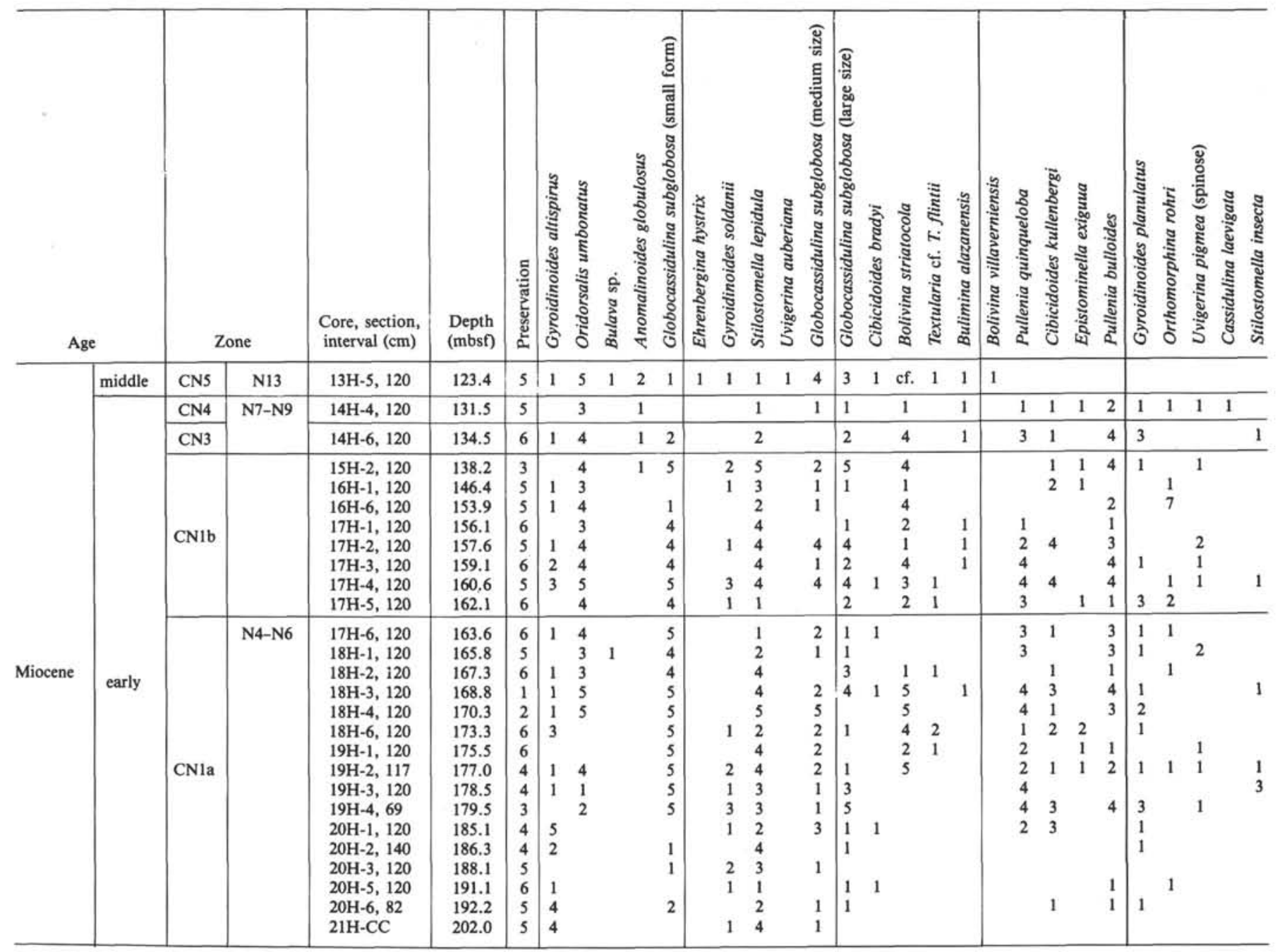

Note: Explanation as in Table 3. 
Table 15 (continued).

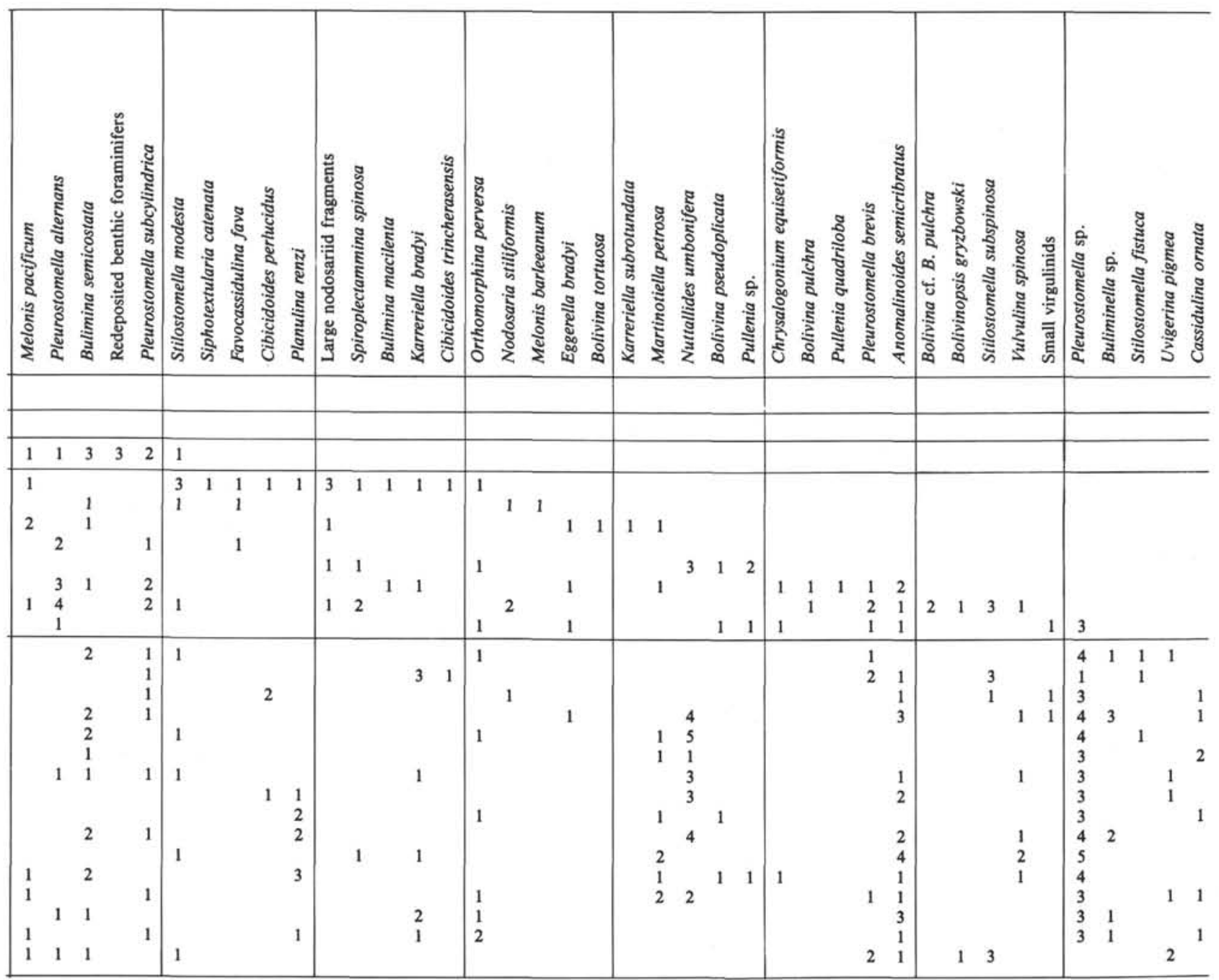


Table 15 (continued).

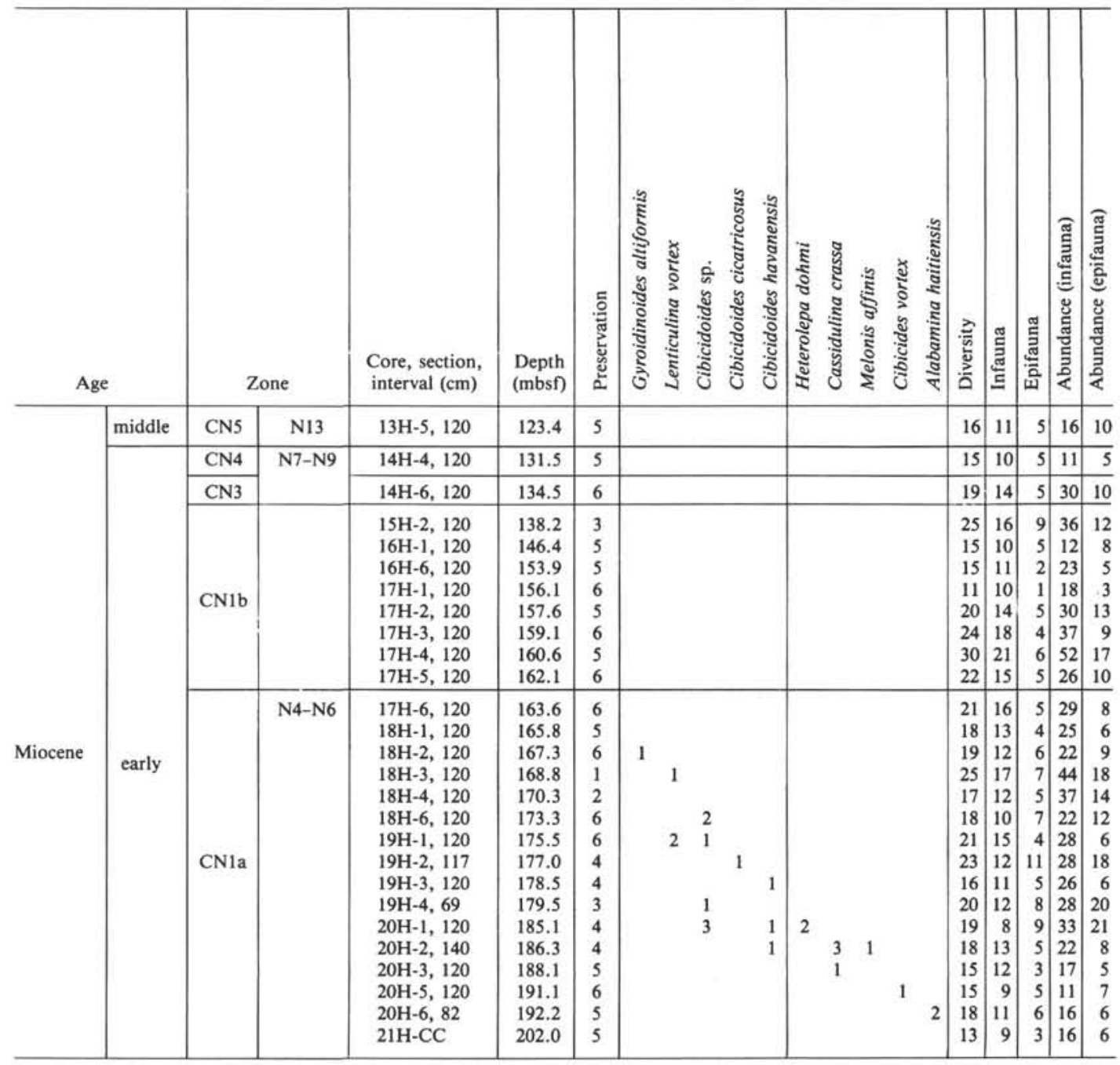



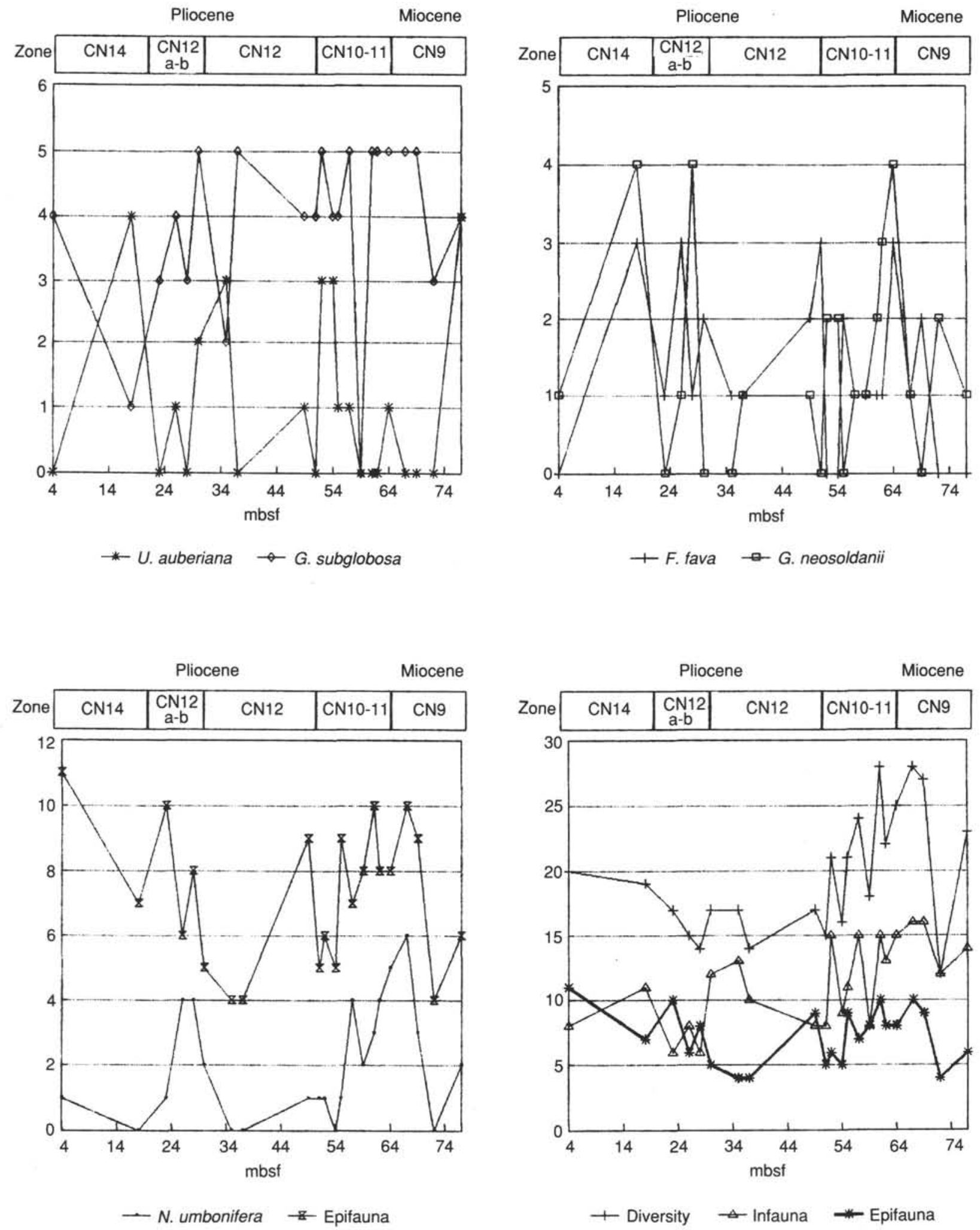

Figure 13. Relative abundances of the most common benthic foraminifers from the late Miocene through the Pliocene at Site 709. Species include Uvigerina auberiana, Globocassidulina subglobosa, Favocassidulina fava, Gyroidinoides neosoldanii, and Nuttallides umbonifera. Diversity and number of epifaunal and infaunal species are also shown. Data from Table 15. Zonation from Backman, Duncan, et al. (1988). 


\section{A. BOERSMA}

Table 16. Ranges of benthic foraminifers through the Neogene in Hole 710A.

\begin{tabular}{|c|c|c|c|c|c|c|c|c|c|c|c|c|c|c|c|c|c|c|c|c|c|c|}
\hline \multicolumn{2}{|c|}{ Age } & \multicolumn{2}{|c|}{ Zone } & \multirow{2}{*}{$\begin{array}{c}\begin{array}{c}\text { Core, section, } \\
\text { interval }(\mathrm{cm})\end{array} \\
1 \mathrm{H}-\mathrm{CC} \\
2 \mathrm{H}-1,120 \\
2 \mathrm{H}-5,120\end{array}$} & \multirow{2}{*}{$\begin{array}{r}\begin{array}{r}\text { Depth } \\
\text { (mbsf) }\end{array} \\
9.5 \\
10.7 \\
16.7\end{array}$} & \multirow{2}{*}{ 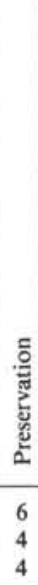 } & \multicolumn{2}{|c|}{ 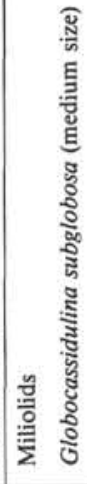 } & 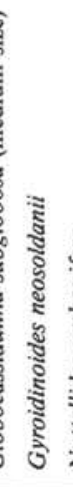 & \multicolumn{2}{|c|}{ 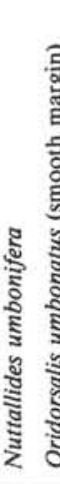 } & \multicolumn{2}{|c|}{ 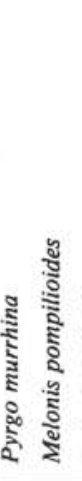 } & 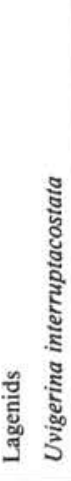 & \multicolumn{4}{|c|}{ 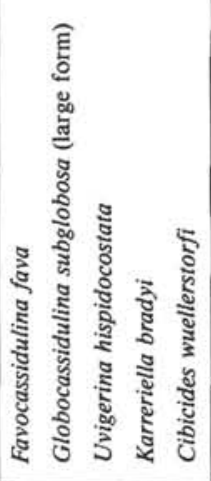 } & \multicolumn{2}{|c|}{ 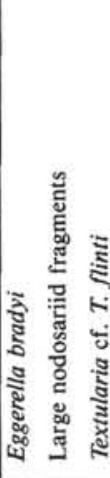 } & \multicolumn{2}{|c|}{ 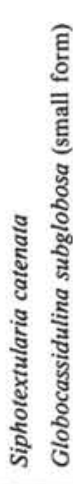 } \\
\hline \multirow[t]{2}{*}{ Pliocene } & late & $\mathrm{CN} 13$ & $\mathrm{~N} 21$ & & & & $\begin{array}{l}3 \\
4\end{array}$ & $\begin{array}{l}3 \\
3\end{array}$ & $\begin{array}{l}1 \\
2\end{array}$ & $\begin{array}{l}1 \\
2\end{array}$ & $\begin{array}{l}5 \\
4 \\
3 \\
\end{array}$ & $\begin{array}{l}3 \\
1\end{array}$ & $\begin{array}{l}1 \\
4 \\
1 \\
\end{array}$ & $\begin{array}{ll}2 & 4 \\
3 & \\
5 & \\
\end{array}$ & $\begin{array}{l}3 \\
1 \\
2\end{array}$ & $\begin{array}{l}4 \\
3 \\
\end{array}$ & $\begin{array}{ll}21 \\
\\
\end{array}$ & $\begin{array}{l}1 \\
1\end{array}$ & $\begin{array}{l}1 \\
1 \\
4 \\
\end{array}$ & $\begin{array}{l}3 \\
\quad 2 \\
\end{array}$ & 3 & $\begin{array}{l}3 \\
1 \\
\end{array}$ \\
\hline & early & $\mathrm{CN} 12$ & N18-N19 & $\begin{array}{l}3 \mathrm{H}-1,120 \\
4 \mathrm{H}-\mathrm{CC}\end{array}$ & $\begin{array}{l}20.4 \\
38.3\end{array}$ & $\begin{array}{l}2 \\
3\end{array}$ & & 3 & $\begin{array}{l}3 \\
3\end{array}$ & $\begin{array}{l}2 \\
1\end{array}$ & $\begin{array}{l}3 \\
5\end{array}$ & $\begin{array}{l}4 \\
1\end{array}$ & 3 & & 1 & 2 & & 3 & 2 & $\begin{array}{l}2 \\
2\end{array}$ & & 1 \\
\hline \multirow{7}{*}{ Miocene } & \multirow{4}{*}{ late } & $\mathrm{CN} 9 \mathrm{~b}$ & N17b & $6 \mathrm{H}-\mathrm{CC}$ & 57.2 & 1 & 2 & & 2 & 2 & 6 & 2 & 3 & 2 & & 3 & & 3 & 2 & 3 & & 5 \\
\hline & & CN9a & N17 & $7 \mathrm{H}-5,120$ & 64.7 & 1 & & 1 & 1 & 4 & 3 & 1 & 1 & 3 & & 3 & & 3 & & & & \\
\hline & & $\mathrm{CN} 8$ & & $8 \mathrm{H}-6,120$ & 75.8 & 1 & & & 2 & 1 & 4 & 1 & 3 & & & & & 3 & & 1 & & 2 \\
\hline & & $\mathrm{CN} 7$ & N16 & $9 \mathrm{H}-2,120$ & 79.3 & 1 & & & 1 & 1 & 4 & & 1 & & & 1 & & 1 & & 3 & & \\
\hline & \multirow{3}{*}{ early } & $\mathrm{CN} 3-\mathrm{CN} 4$ & N5-N7 & $12 \mathrm{H}-\mathrm{CC}$ & 115.2 & 1 & & & 5 & 5 & 6 & & 5 & & & & & & 1 & & & 5 \\
\hline & & $\mathrm{CN} 2$ & \multirow[b]{2}{*}{$\mathrm{N} 4$} & $13 \mathrm{H}-\mathrm{CC}$ & 124.8 & 1 & & 5 & 5 & 5 & 5 & & 3 & & 2 & 1 & & & & 3 & & 3 \\
\hline & & $\mathrm{CN} 1$ & & $15 \mathrm{X}-\mathrm{CC}$ & 139.4 & 1 & & 5 & & & 5 & & & & & 1 & & & & & & 3 \\
\hline
\end{tabular}

Note: Explanation as in Table 3. 
Table 16 (continued).

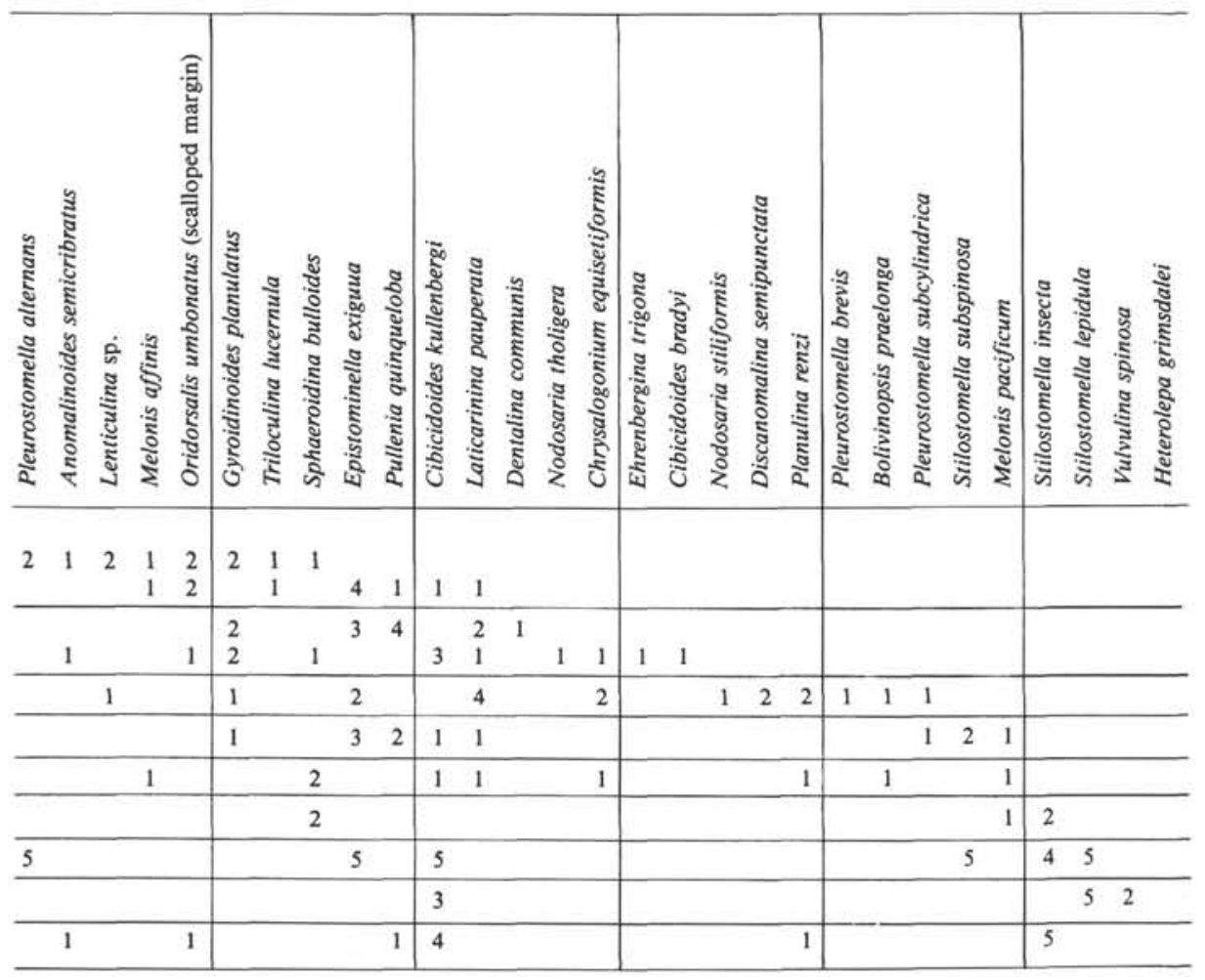


Table 17. Ranges of benthic foraminifers through the late Neogene in Hole 713A.

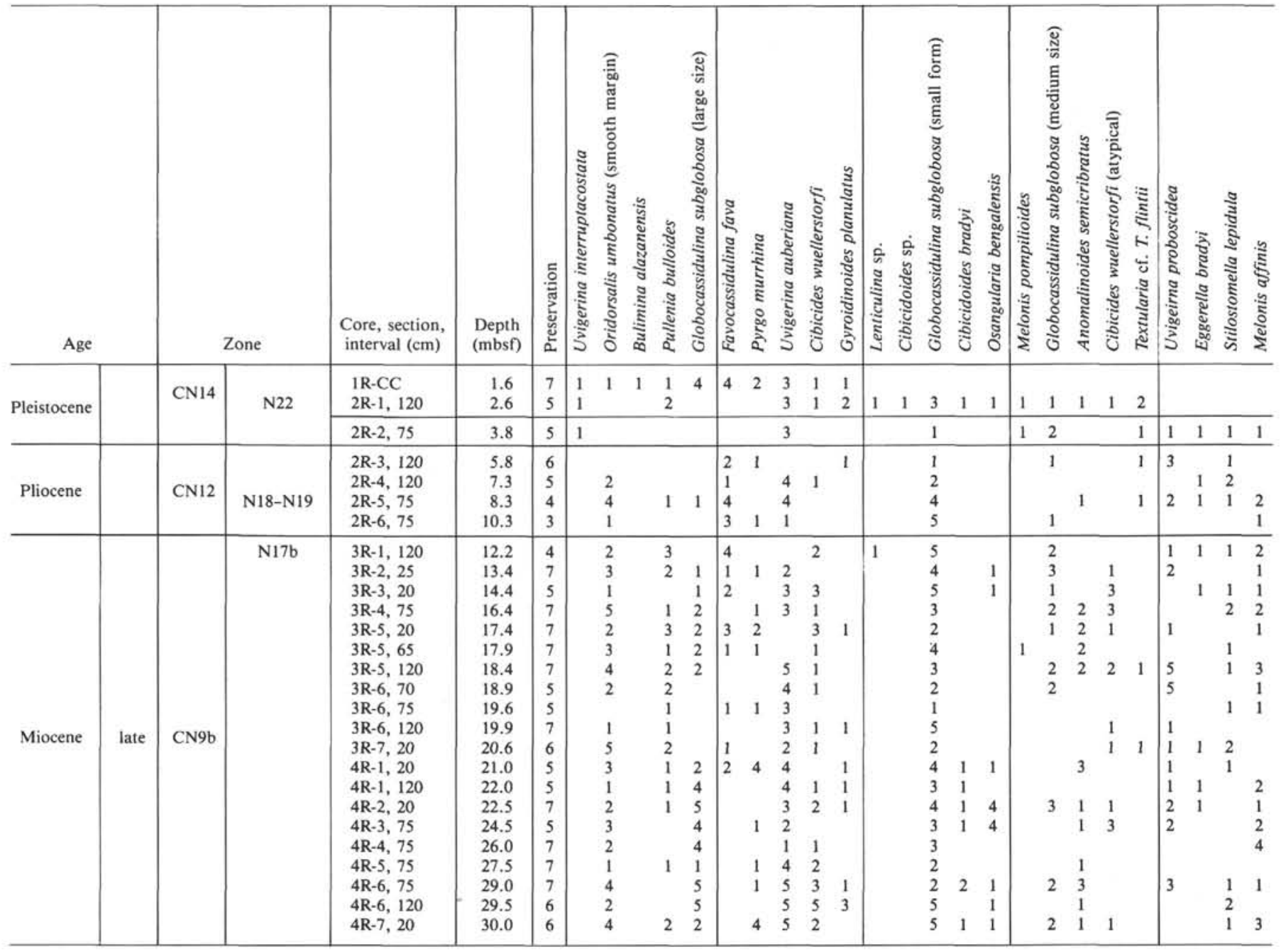

Note: Explanation as in Table 3. 
Table 17 (continued).

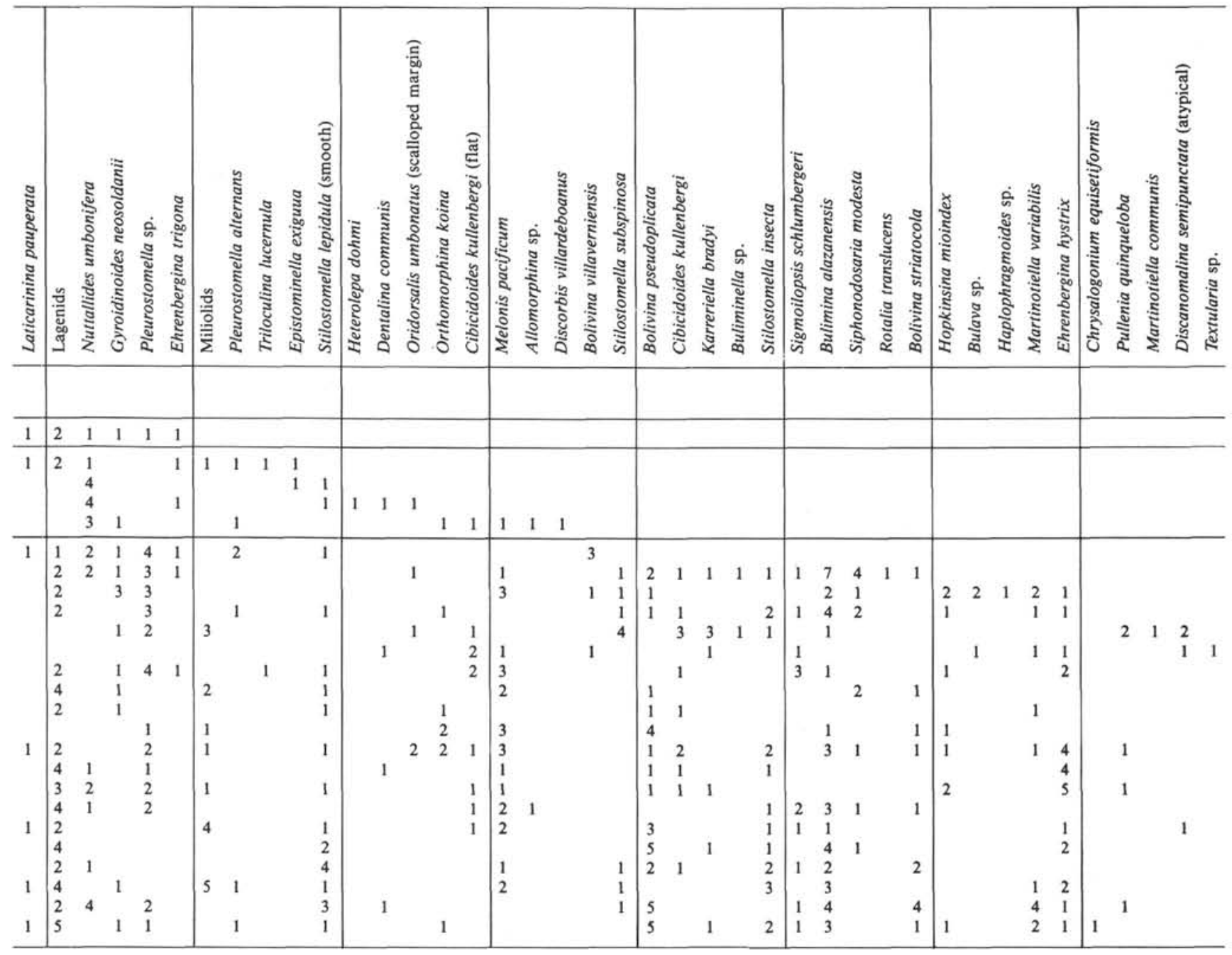


Table 17 (continued).

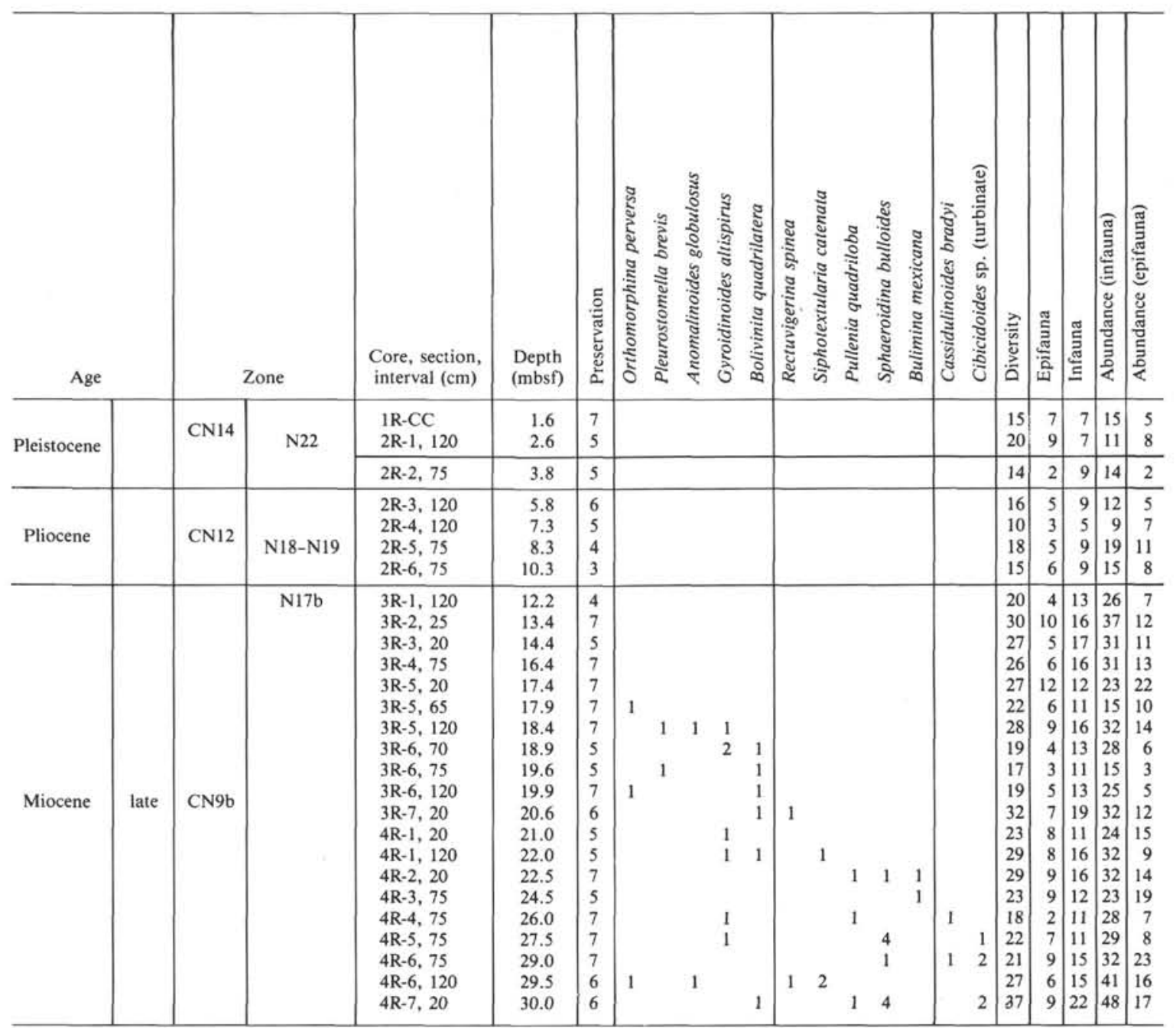


Table 18. Ranges of benthic foraminifers through the Neogene at Site 219.

\begin{tabular}{|c|c|c|c|c|c|c|c|c|c|c|c|c|c|c|c|c|c|c|c|c|c|c|c|c|c|c|c|}
\hline \multicolumn{2}{|c|}{ Age } & \multicolumn{2}{|c|}{ Zone } & \multirow{2}{*}{$\begin{array}{c}\text { Core, section, } \\
\text { interval }(\mathrm{cm})\end{array}$} & \multirow[t]{2}{*}{ 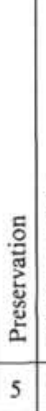 } & \multirow{2}{*}{\multicolumn{2}{|c|}{ 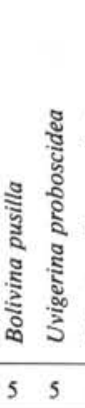 }} & \multirow[t]{2}{*}{ 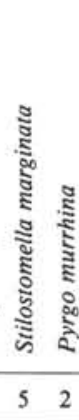 } & \multirow[t]{2}{*}{ 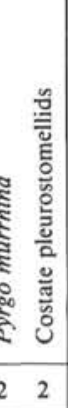 } & \multirow[t]{2}{*}{ 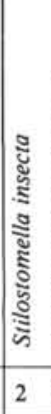 } & \multirow{2}{*}{\multicolumn{2}{|c|}{ 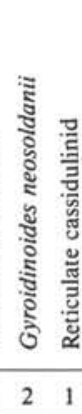 }} & \multirow[t]{2}{*}{ 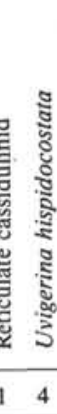 } & \multirow[t]{2}{*}{ 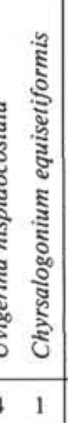 } & \multirow[t]{2}{*}{ 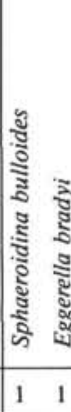 } & \multirow{2}{*}{\multicolumn{3}{|c|}{ 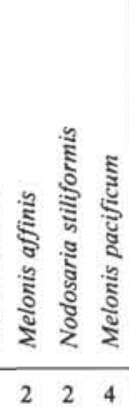 }} & \multirow{2}{*}{\multicolumn{2}{|c|}{ 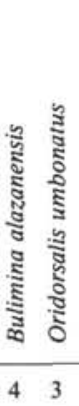 }} & 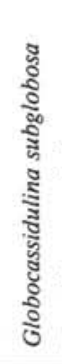 & \multirow[t]{2}{*}{ 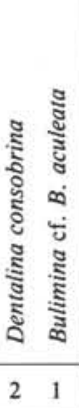 } & \multicolumn{2}{|c|}{ 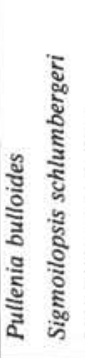 } & \multicolumn{2}{|c|}{ 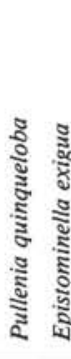 } & 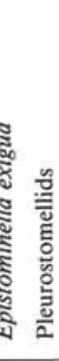 \\
\hline \multirow{3}{*}{ Pliocene } & late & $\mathrm{CN}_{12}$ & $\mathrm{~N} 21$ & & & & & & & & & & & & & 1 & & & & & 1 & & 2 & 4 & 1 & 3 & 4 \\
\hline & \multirow[b]{2}{*}{ early } & $\mathrm{CN} 11$ & $\mathrm{~N} 19-\mathrm{N} 20$ & $\begin{array}{l}5-1,70 \\
5-2,97 \\
5-3,73\end{array}$ & $\begin{array}{l}4 \\
5 \\
3 \\
\end{array}$ & \begin{tabular}{|l|}
5 \\
6 \\
6 \\
\end{tabular} & $\begin{array}{l}5 \\
6 \\
5\end{array}$ & $\begin{array}{ll}5 & 1 \\
5 & 3 \\
4 & 2 \\
\end{array}$ & $\begin{array}{l}1 \\
3 \\
2\end{array}$ & $\begin{array}{l}1 \\
5\end{array}$ & $\begin{array}{l}1 \\
3 \\
3\end{array}$ & & $\begin{array}{l}5 \\
1 \\
5 \\
\end{array}$ & 2 & & $\begin{array}{l}1 \\
1 \\
4\end{array}$ & $\begin{array}{l}1 \\
1 \\
4\end{array}$ & 11 & $\begin{array}{l}5 \\
5 \\
5\end{array}$ & $\begin{array}{l}5 \\
2 \\
3 \\
\end{array}$ & $\begin{array}{l}3 \\
3 \\
5 \\
\end{array}$ & $\begin{array}{l}3 \\
3\end{array}$ & $\begin{array}{l}2 \\
1 \\
4 \\
\end{array}$ & $\begin{array}{l}1 \\
1 \\
2\end{array}$ & $\begin{array}{l}1 \\
1\end{array}$ & $\begin{array}{l}1 \\
5 \\
3\end{array}$ & $\begin{array}{l}1 \\
4\end{array}$ \\
\hline & & $\mathrm{CN} 10$ & N18 & $\begin{array}{l}6-2,65 \\
6-5,73 \\
7-4,73 \\
8-3,67\end{array}$ & $\begin{array}{l}3 \\
5 \\
5\end{array}$ & $\begin{array}{l}5 \\
5 \\
5\end{array}$ & $\begin{array}{l}4 \\
4 \\
5\end{array}$ & $\begin{array}{l}1 \\
2 \\
1\end{array}$ & $\begin{array}{l}1 \\
1\end{array}$ & 1 & $\begin{array}{l}1 \\
2\end{array}$ & $\begin{array}{l}3 \\
1\end{array}$ & 1 & $\begin{array}{l}1 \\
2 \\
1\end{array}$ & $\begin{array}{l}2 \\
3\end{array}$ & $\begin{array}{l}5 \\
3 \\
2\end{array}$ & $\begin{array}{l}5 \\
3 \\
2\end{array}$ & 1 & 5 & $\begin{array}{l}3 \\
5 \\
1\end{array}$ & $\begin{array}{l}5 \\
6 \\
5\end{array}$ & & $\begin{array}{l}1 \\
1\end{array}$ & $\begin{array}{l}1 \\
2 \\
2\end{array}$ & $\begin{array}{l}4 \\
1\end{array}$ & $\begin{array}{l}3 \\
2\end{array}$ & $\begin{array}{l}2 \\
3 \\
5\end{array}$ \\
\hline \multirow{3}{*}{ Miocene } & late & CN9 & N17 & $\begin{array}{l}8-4,70 \\
10-6,70\end{array}$ & $\begin{array}{l}5 \\
4\end{array}$ & $\begin{array}{l}2 \\
1\end{array}$ & $\begin{array}{l}5 \\
5\end{array}$ & $\begin{array}{l}2 \\
5\end{array}$ & 3 & 3 & $\begin{array}{l}1 \\
1\end{array}$ & 1 & $\begin{array}{l}1 \\
2\end{array}$ & $\begin{array}{l}2 \\
1\end{array}$ & 1 & $\begin{array}{l}1 \\
1\end{array}$ & $\begin{array}{l}5 \\
5 \\
\end{array}$ & 1 & 5 & $\begin{array}{l}4 \\
5\end{array}$ & $\begin{array}{l}5 \\
5\end{array}$ & $\begin{array}{l}1 \\
1\end{array}$ & $\begin{array}{l}2 \\
1 \\
\end{array}$ & 1 & $\begin{array}{l}2 \\
1\end{array}$ & 1 & $\begin{array}{l}3 \\
3 \\
\end{array}$ \\
\hline & middle & CN5 & N10 & $\begin{array}{l}13-1,24 \\
13-1,130 \\
13-6,95\end{array}$ & $\begin{array}{l}6 \\
5 \\
5 \\
\end{array}$ & & 1 & $\begin{array}{l}1 \\
1 \\
\end{array}$ & & & & & & & 2 & & 1 & ff. & & & $\begin{array}{l}5 \\
1 \\
5 \\
\end{array}$ & & 2 & & & & 1 \\
\hline & early & $\mathrm{CN} 4$ & N7-N8 & $14-3,102$ & 5 & & & & & 1 & & & & 1 & 1 & & 1 & & & 3 & & & & & & & \\
\hline
\end{tabular}

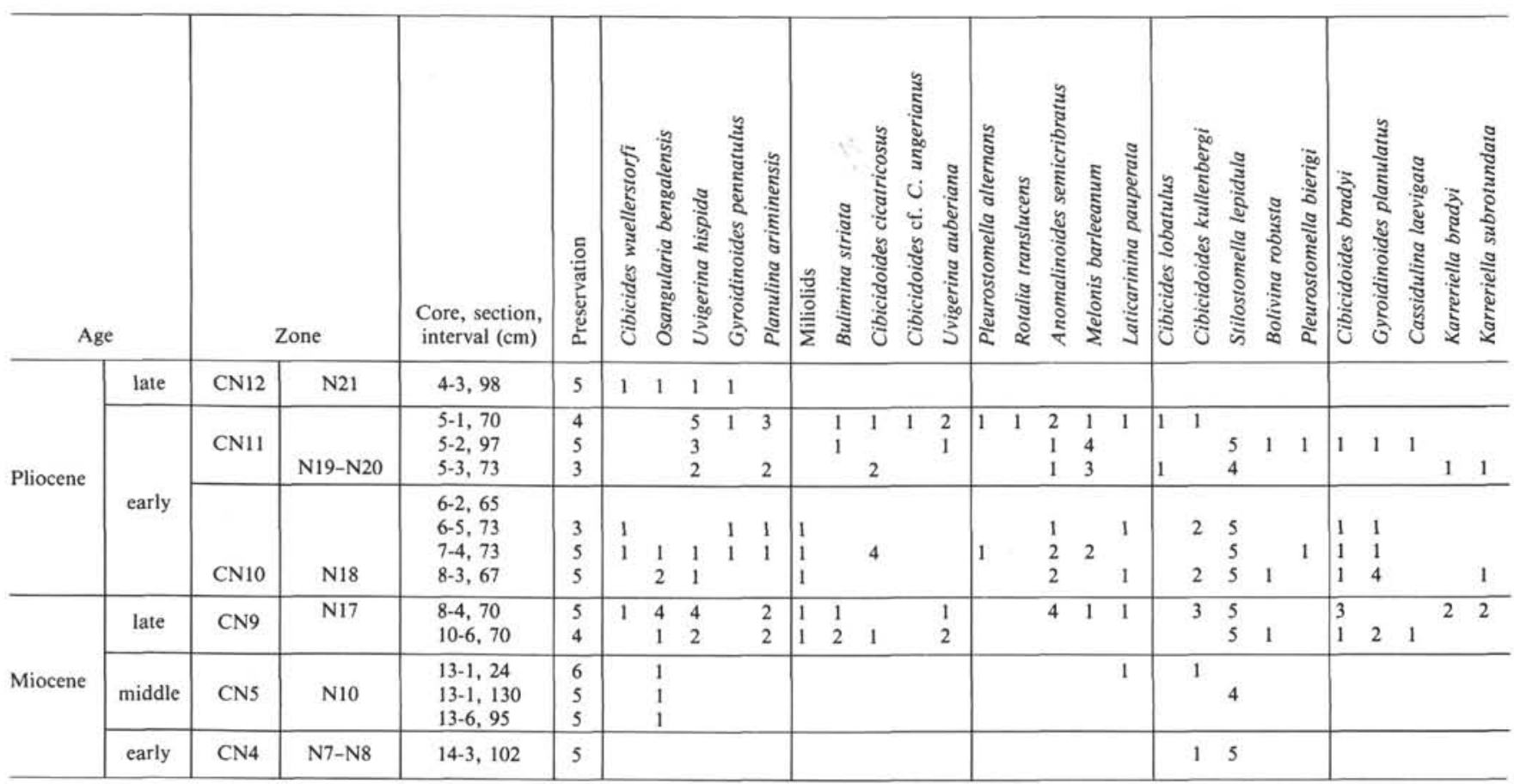

Note: Explanation as in Table 3. 
Table 18 (continued).

\begin{tabular}{|c|c|c|c|c|c|c|c|c|c|c|c|c|c|c|c|c|c|c|c|c|c|c|}
\hline \multicolumn{2}{|c|}{ Age } & \multicolumn{2}{|c|}{ Zone } & \multirow{2}{*}{$\begin{array}{c}\text { Core, section, } \\
\text { interval }(\mathrm{cm})\end{array}$} & \multirow[t]{2}{*}{ 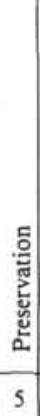 } & 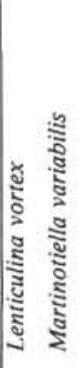 & : & \multicolumn{2}{|c|}{ 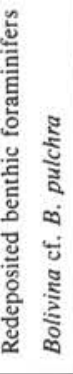 } & \multicolumn{2}{|c|}{ 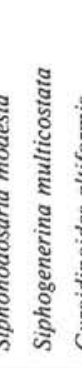 } & \multicolumn{2}{|c|}{ 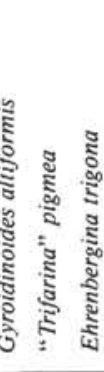 } & & \multirow{2}{*}{\multicolumn{2}{|c|}{ 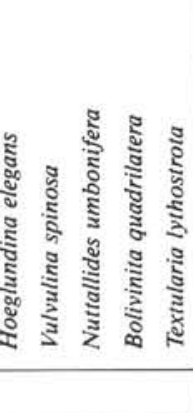 }} & \multirow{2}{*}{\multicolumn{3}{|c|}{ 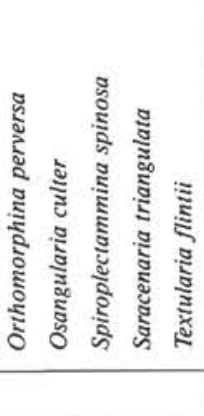 }} & \multirow{2}{*}{\multicolumn{2}{|c|}{ 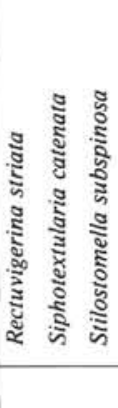 }} & \multirow[t]{2}{*}{ 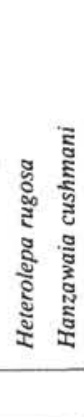 } \\
\hline \multirow{3}{*}{ Pliocene } & late & $\mathrm{CN} 12$ & $\mathrm{~N} 21$ & & & & & & & 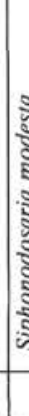 & & & & & & & & & & & & \\
\hline & \multirow[b]{2}{*}{ early } & $\mathrm{CN} 11$ & $\mathrm{~N} 19-\mathrm{N} 20$ & $\begin{array}{l}5-1,70 \\
5-2,97 \\
5-3,73\end{array}$ & $\begin{array}{l}4 \\
5 \\
3 \\
\end{array}$ & & & & & & & & & & & & & & & & & \\
\hline & & $\mathrm{CN} 10$ & N18 & $\begin{array}{l}6-2,65 \\
6-5,73 \\
7-4,73 \\
8-3,67\end{array}$ & $\begin{array}{l}3 \\
5 \\
5\end{array}$ & $\begin{array}{l}1 \\
1 \\
1\end{array}$ & $\begin{array}{l}1 \\
3 \\
1\end{array}$ & $\begin{array}{l}1 \\
1\end{array}$ & $\begin{array}{l}1 \\
5\end{array}$ & $\begin{array}{l}2 \\
5\end{array}$ & $\begin{array}{l}4 \\
2\end{array}$ & 2 & $\begin{array}{ll}1 & 1 \\
& 1\end{array}$ & $\begin{array}{l}1 \\
1\end{array}$ & 1 & 11 & & & & & & \\
\hline \multirow{3}{*}{ Miocene } & late & $\mathrm{CN} 9$ & N17 & $\begin{array}{l}8-4,70 \\
10-6,70\end{array}$ & $\begin{array}{l}5 \\
4 \\
\end{array}$ & $\begin{array}{l}1 \\
1\end{array}$ & $\begin{array}{l}5 \\
2\end{array}$ & 4 & $\begin{array}{l}5 \\
3\end{array}$ & $\begin{array}{l}2 \\
1\end{array}$ & 4 & 11 & 11 & & 1 & $\begin{array}{l}3 \\
1 \\
\end{array}$ & $\begin{array}{ll}1 & 2 \\
1 & \end{array}$ & 1 & 11 & & & \\
\hline & middle & CNS & N10 & $\begin{array}{l}13-1,24 \\
13-1,130 \\
13-6,95\end{array}$ & $\begin{array}{l}6 \\
5 \\
5 \\
\end{array}$ & $\begin{array}{ll}1 & 2 \\
2 & 1 \\
1 & \\
\end{array}$ & & 1 & & 1 & 1 & & & & 1 & & $\begin{array}{l}1 \\
1 \\
\end{array}$ & 1 & & $\begin{array}{ll}1 & 1\end{array}$ & $\begin{array}{l}1 \\
1\end{array}$ & $\begin{array}{ll}1 & 1 \\
1 & 1 \\
\end{array}$ \\
\hline & early & $\mathrm{CN} 4$ & N7-N8 & $14-3,102$ & 5 & & & & & & & 1 & & & & & & & & & & \\
\hline
\end{tabular}

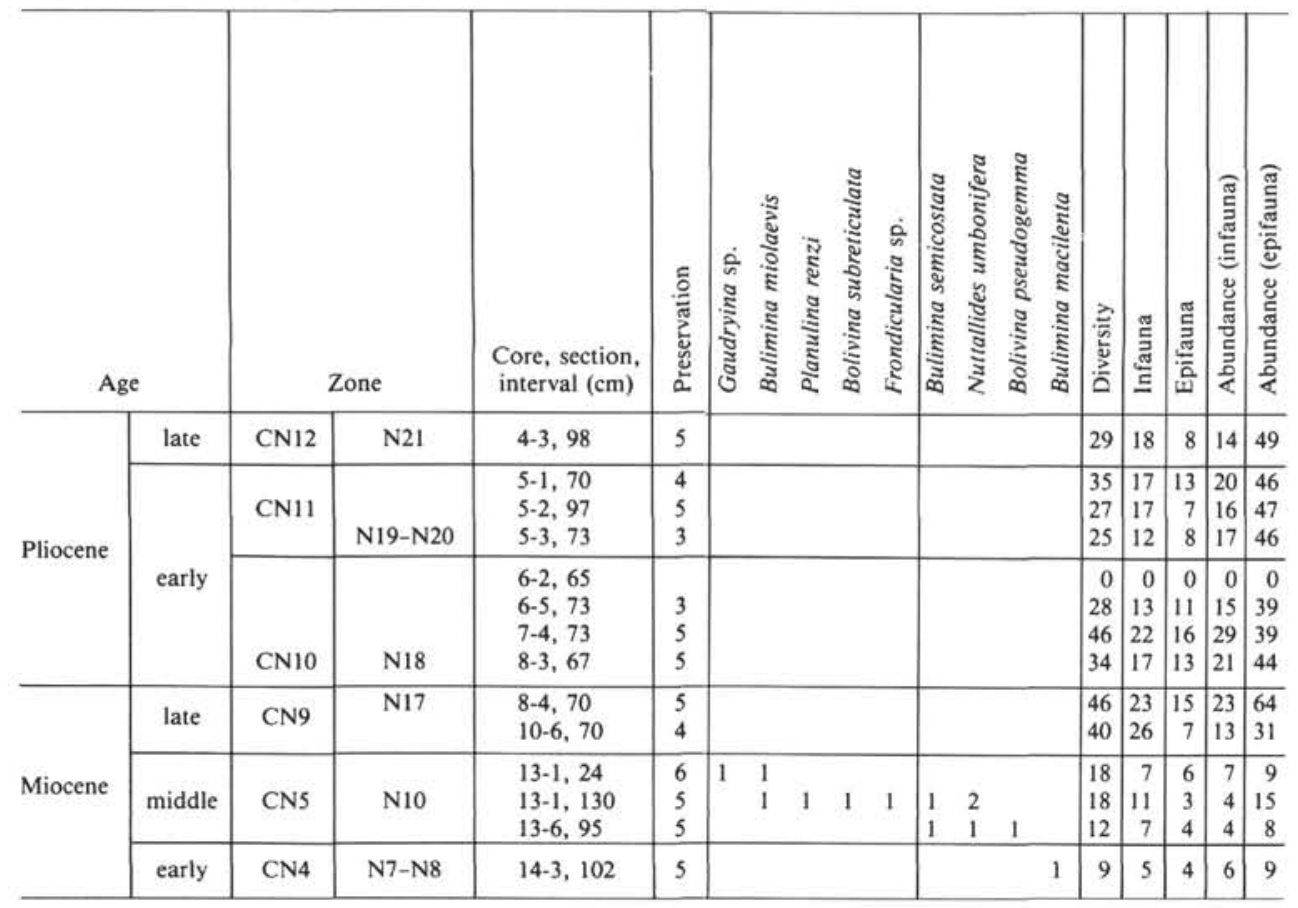


Mascarene Basin

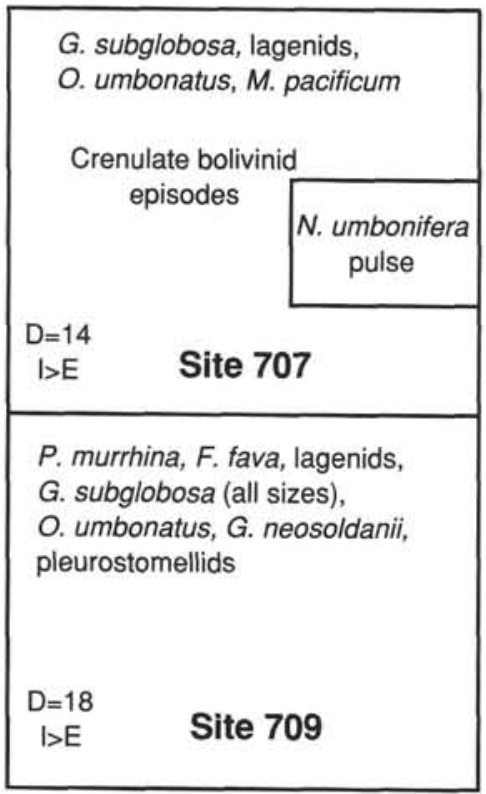

Proto-

AAIW

\section{Less}

fertile

proto-

IDW

Arabian Sea

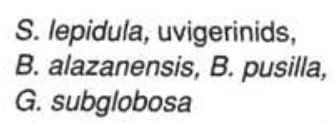

S. lepidula, uvigerinids,

B. alazanensis, B. pusilla,

G. subglobosa

\section{E. exiguua B. cf. cincta \\ Miliolids}

$P$. quinqueloba

$D=35$

$1 \gg E$

\section{Site 219}

Proto-

NIIW

Time slice

N18

Figure 14. Benthic foraminifer index faunas of early Pliocene Zone N18 (= Zones CN10-CN11) from six sites in the western and central Indian Ocean. Indexes, listed at top, were most abundant or most consistently present. Index forms that occurred only in pulses or events are shown below. Total sample diversity and the relation of infaunal abundance to epifaunal abundance are shown at bottom left of each box. The faunal name assigned to each index fauna is listed to the right of each box. Data from Tables 15-19. 
Table 19. Ranges of benthic foraminifers from the late Miocene through the Pleistocene in Hole 707A.

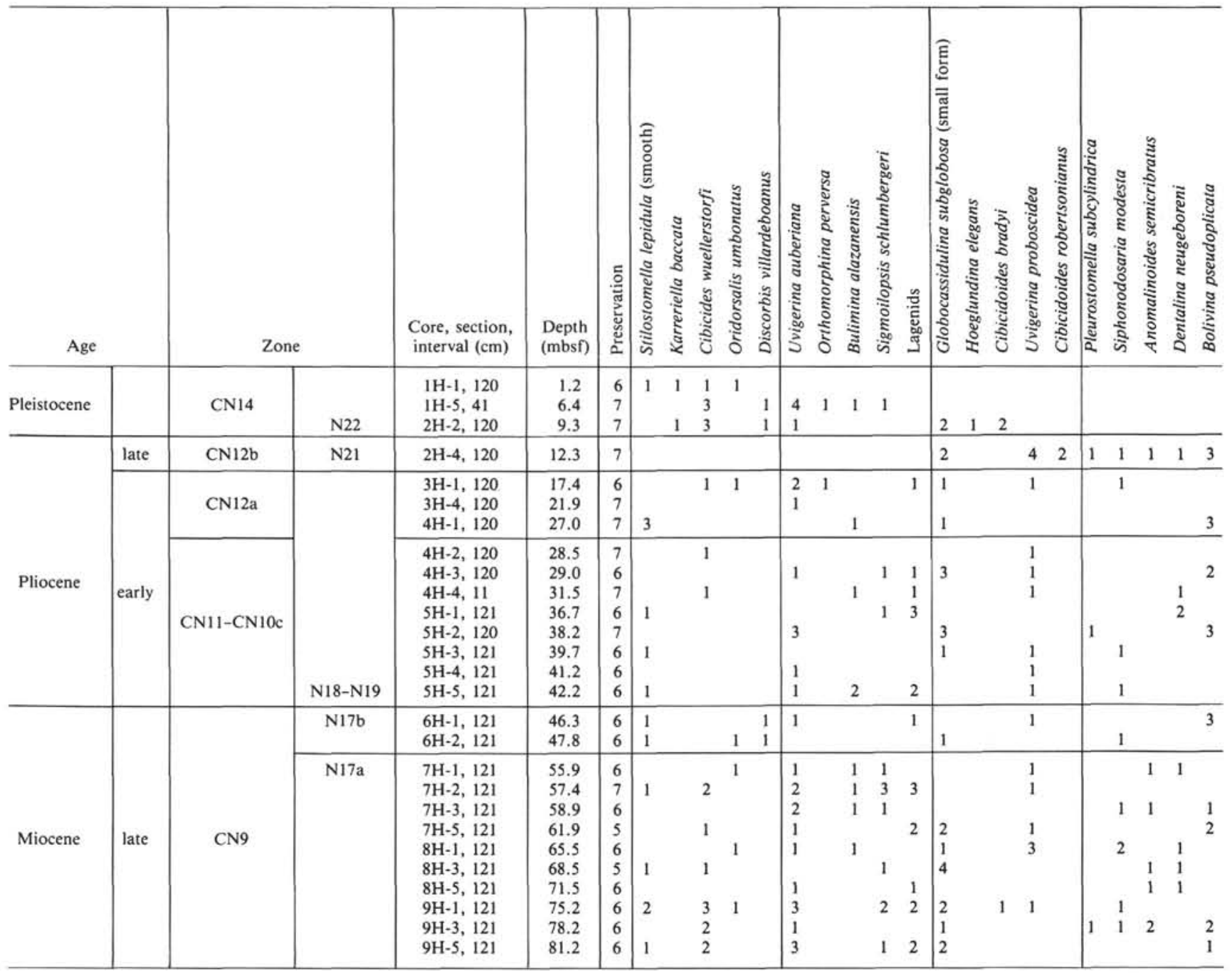

Note: Explanation as in Table 3. 
Table 19 (continued).

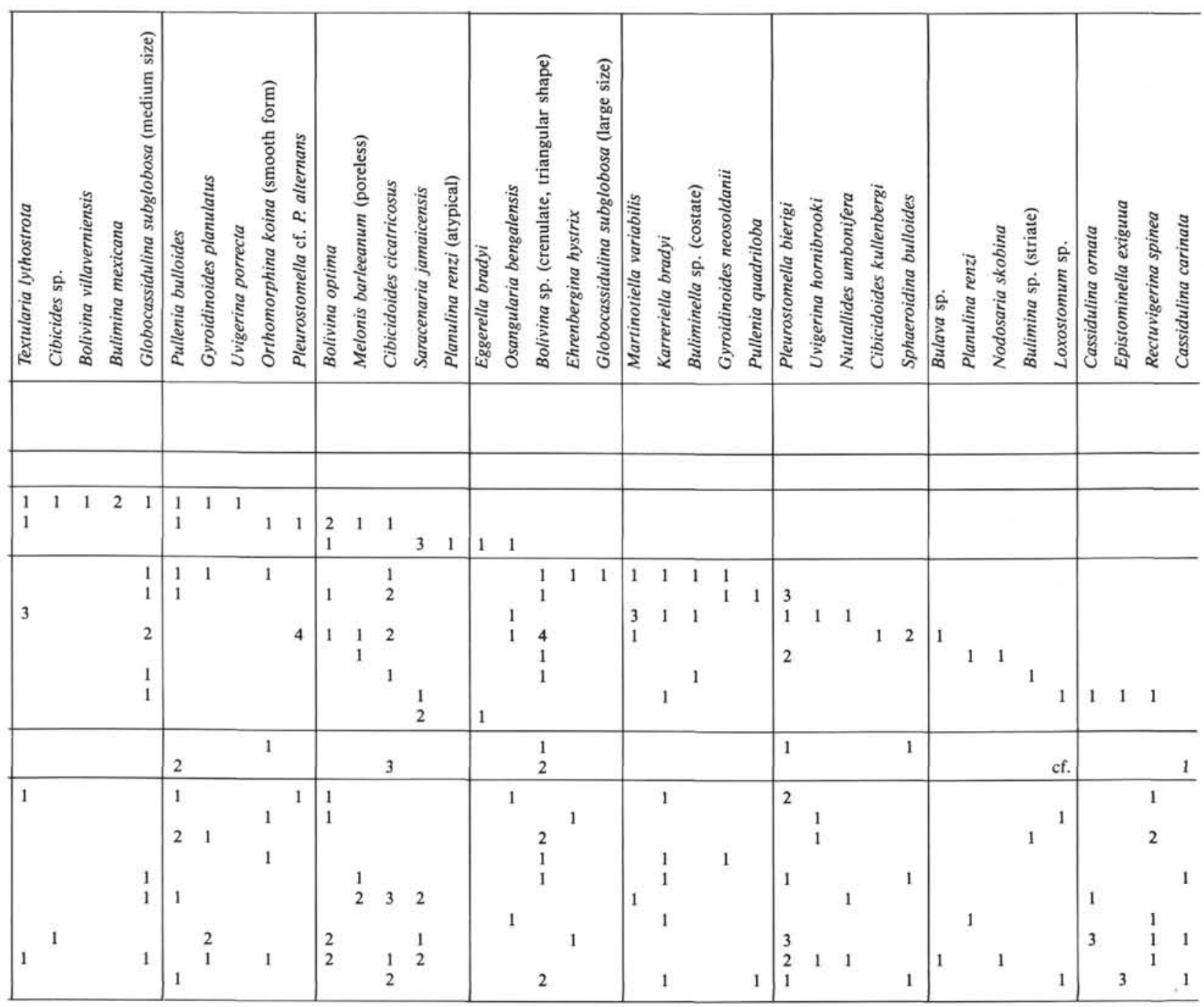




\section{A. BOERSMA}

Table 19 (continued).

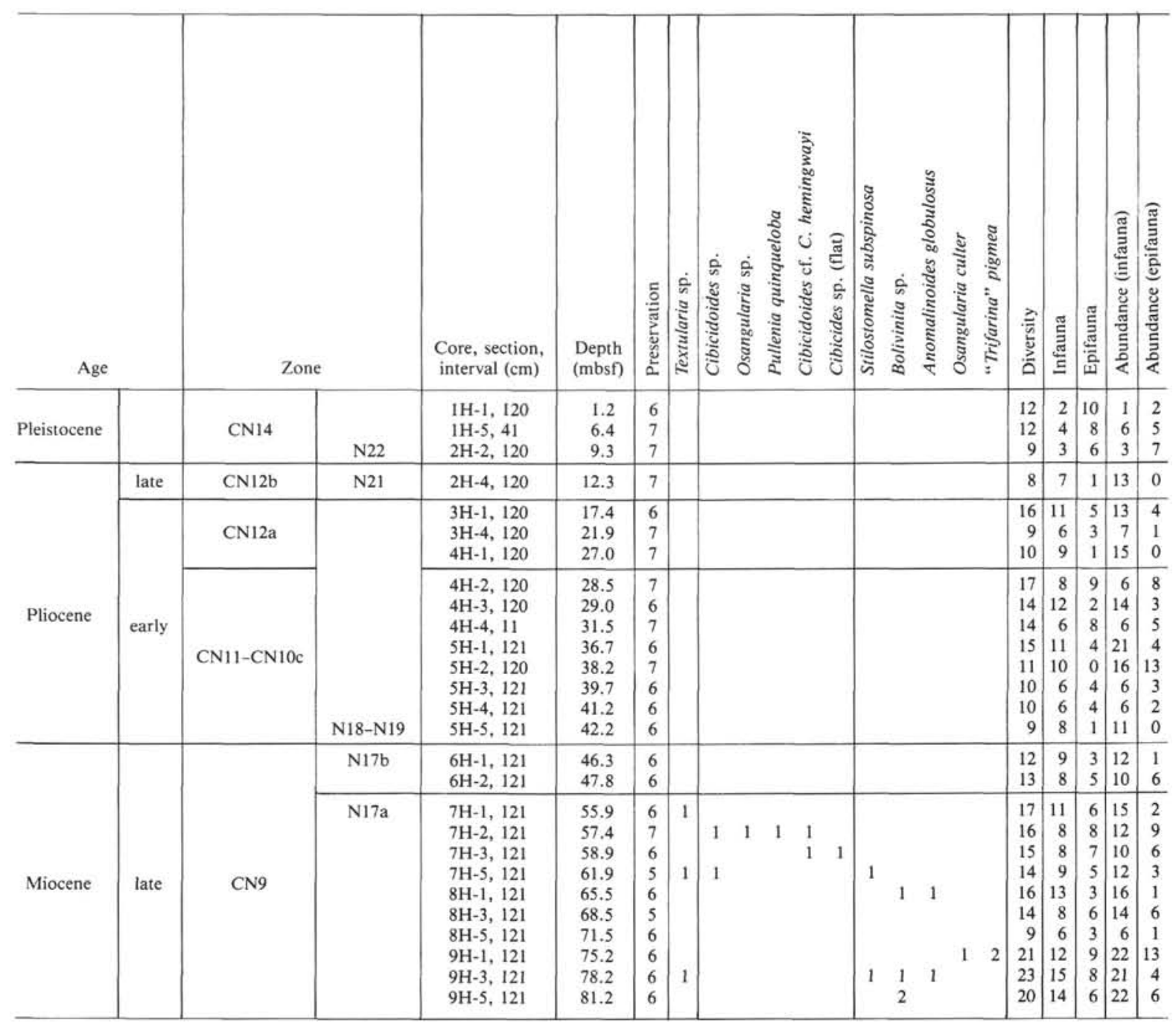



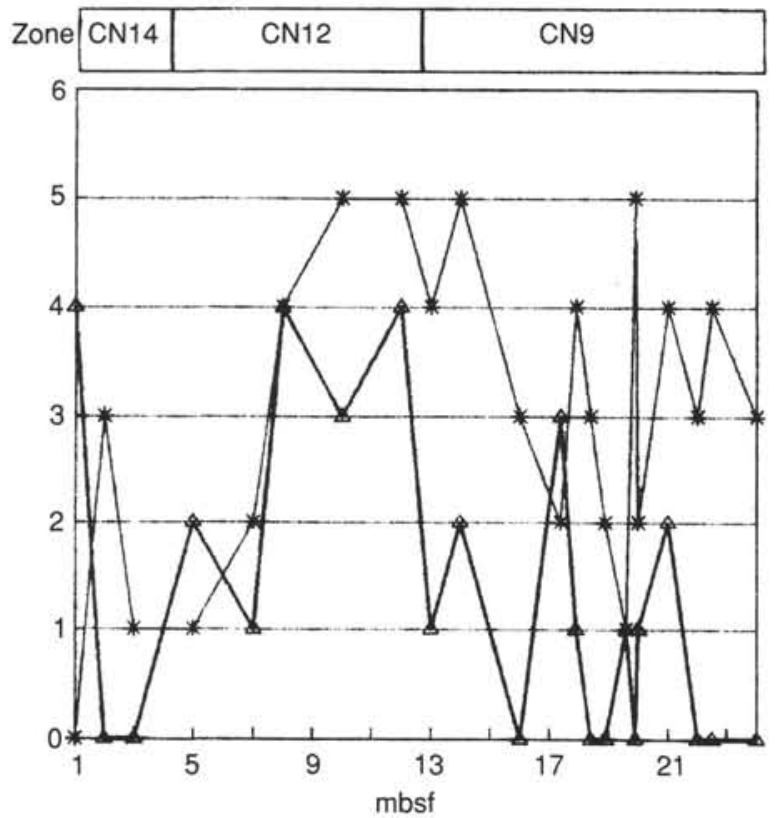

*-G. subglobosa $-F$ fava
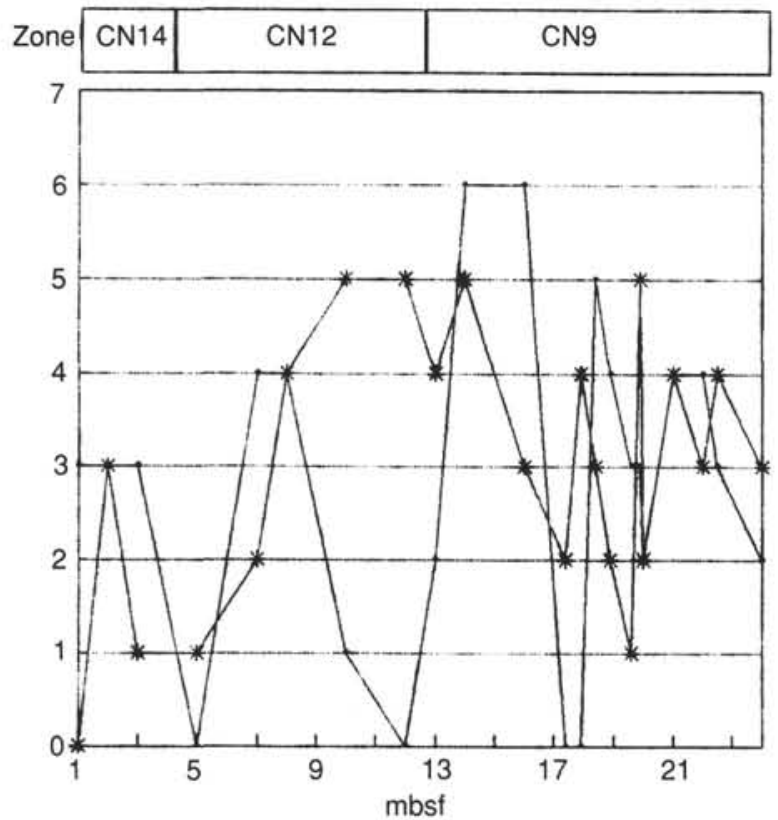

- U. auberiana * G. subglobosa

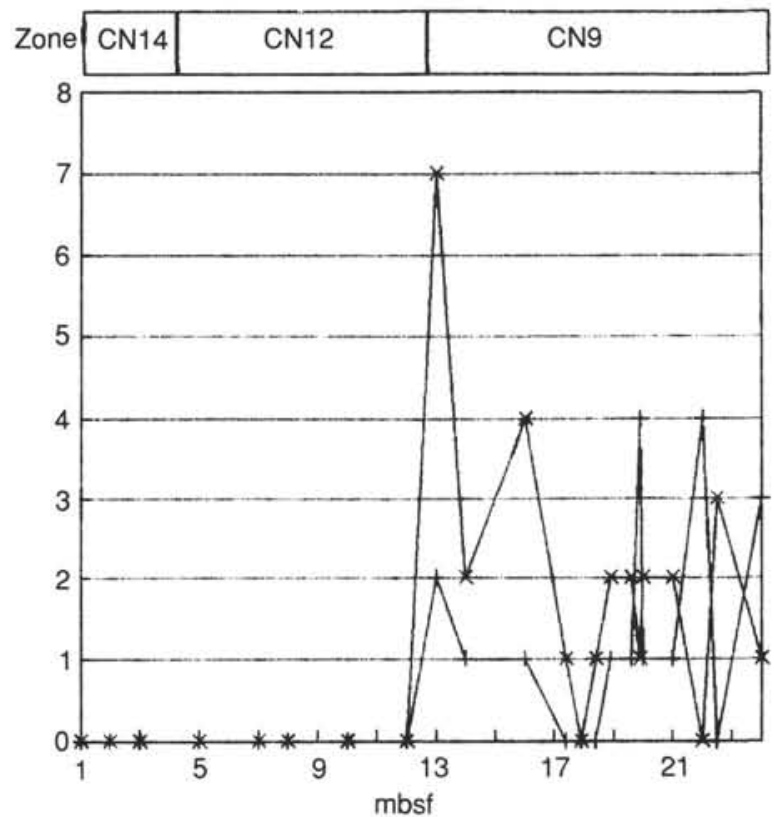

+ Crenulate Bol. $\quad *$ B. alazanensis
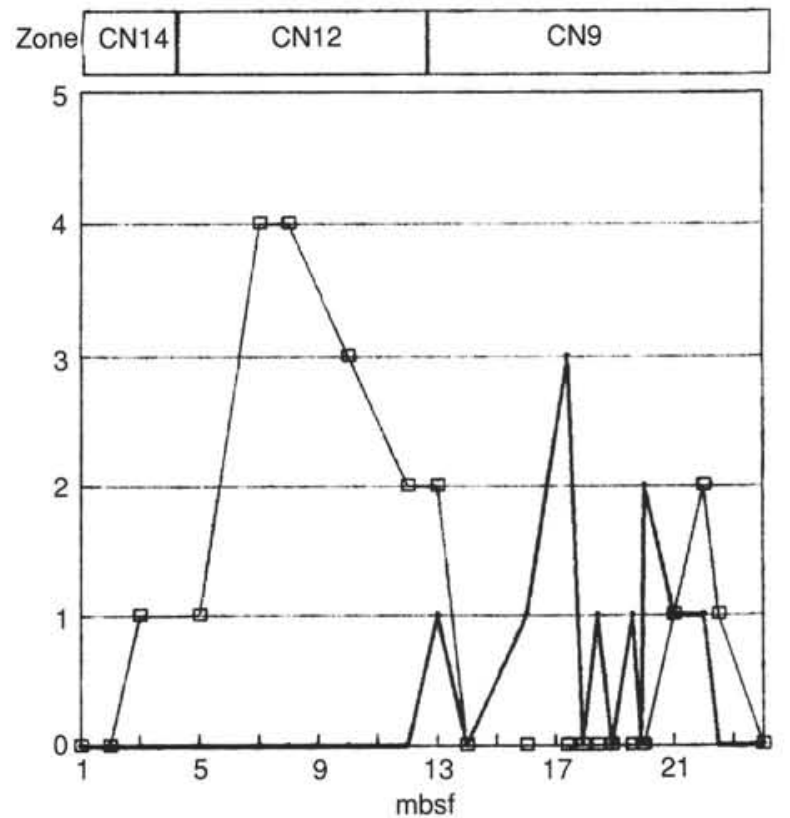

N. umbonifera - C. kullenbergi

Figure 15. Relative abundances of most common species during the late Miocene through the Pliocene at Site 713. Species include Globocassidulina subglobosa, Favocassidulina fava, Bulimina alazanensis, Uvigerina auberiana, Nuttallides umbonifera, all crenulate bolivinids counted together, and Cibicidoides kullenbergi. Data from Table 17. Zonation from Backman, Duncan, et al. (1988). 
Table 20. Ranges of benthic foraminifers from the late Miocene through the Pliocene in Hole 709A.

\begin{tabular}{|c|c|c|c|c|c|c|c|c|c|c|c|c|c|c|c|c|c|c|c|c|c|c|c|c|}
\hline \multicolumn{2}{|l|}{ Age } & \multicolumn{2}{|c|}{ Zone } & \multirow{2}{*}{$\begin{array}{c}\begin{array}{c}\text { Core, section, } \\
\text { interval }(\mathrm{cm})\end{array} \\
1 \mathrm{H}-3,120 \\
2 \mathrm{H}-6,60\end{array}$} & \multirow{2}{*}{\begin{tabular}{r|}
$\begin{array}{r}\text { Depth } \\
\text { (mbsf) }\end{array}$ \\
4.2 \\
18.1
\end{tabular}} & \multirow{2}{*}{ 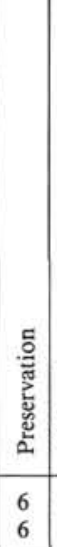 } & 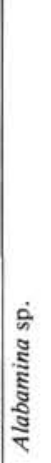 & \multicolumn{2}{|c|}{ 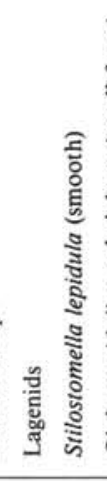 } & \multicolumn{2}{|c|}{ 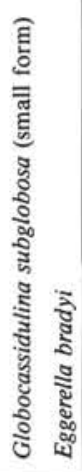 } & \multicolumn{2}{|c|}{ 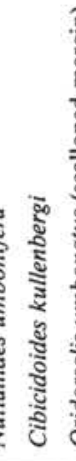 } & \multirow{2}{*}{\multicolumn{2}{|c|}{ 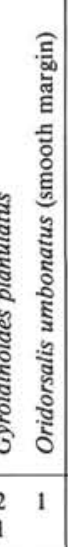 }} & \multirow[t]{2}{*}{ 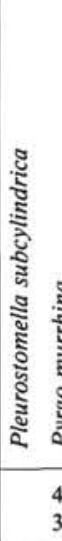 } & \multicolumn{2}{|c|}{ 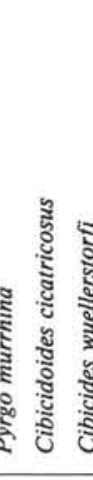 } & \multirow{2}{*}{ 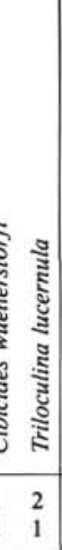 } & \multirow{2}{*}{\multicolumn{2}{|c|}{ 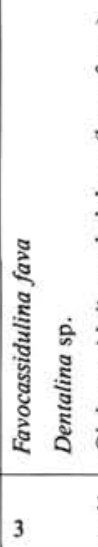 }} & \multicolumn{2}{|c|}{ 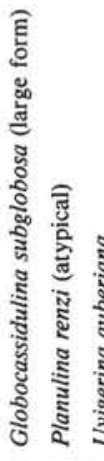 } & \\
\hline Pleistocene & & $\mathrm{CN} 14$ & $\mathrm{~N} 22$ & & & & 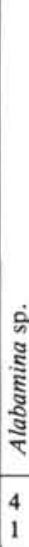 & $\begin{array}{l}4 \\
2\end{array}$ & & $\begin{array}{ll}4 & 3 \\
1 & 1\end{array}$ & $\begin{array}{l}3 \\
1\end{array}$ & 1 & 1 & & & & $\begin{array}{ll}4 & 1 \\
3 & \end{array}$ & 1 & & & & $\begin{array}{l}5 \\
1\end{array}$ & 4 & \\
\hline \multirow{5}{*}{ Pliocene } & late & $\mathrm{CN} 12 \mathrm{a}-\mathrm{CN} 12 \mathrm{c}$ & $\mathrm{N} 21$ & $\begin{array}{l}3 \mathrm{H}-3,120 \\
3 \mathrm{H}-5,120 \\
3 \mathrm{H}-6,120\end{array}$ & $\begin{array}{l}23.9 \\
26.9 \\
28.4\end{array}$ & \begin{tabular}{l|}
6 \\
5 \\
6 \\
\end{tabular} & $\begin{array}{l}1 \\
1\end{array}$ & $\begin{array}{l}2 \\
2 \\
\end{array}$ & $\begin{array}{l}1 \\
1 \\
\end{array}$ & $\begin{array}{ll}3 & 1 \\
4 & 3 \\
3 & \\
\end{array}$ & \begin{tabular}{l|l}
1 & 1 \\
3 & 4 \\
& 4 \\
\end{tabular} & $\begin{array}{ll}1 & 1 \\
4 & \\
4 & \\
\end{array}$ & $\begin{array}{l}1 \\
1\end{array}$ & 1 & \begin{tabular}{l|}
2 \\
4 \\
1 \\
\end{tabular} & cf. & $\begin{array}{l}4 \text { cf } \\
4 \\
4\end{array}$ & ff. & $\begin{array}{l}1 \\
1\end{array}$ & \begin{tabular}{|l|}
1 \\
3 \\
1 \\
\end{tabular} & 1 & & 1 & \\
\hline & \multirow{4}{*}{ early } & $\mathrm{CN} 12 \mathrm{a}$ & & $4 \mathrm{H}-1,120$ & 30.6 & 4 & & 2 & 1 & 5 & & 2 & & & 1 & & 4 & & & 2 & 1 & 5 & 13 & \\
\hline & & CN11 & & $\begin{array}{l}4 \mathrm{H}-4,120 \\
4 \mathrm{H}-5,120 \\
\end{array}$ & $\begin{array}{c}35.1 \\
?\end{array}$ & $\begin{array}{l}4 \\
3 \\
\end{array}$ & & 3 & & $\begin{array}{ll}2 & 1 \\
5 & \\
\end{array}$ & & & & & \begin{tabular}{l|}
4 \\
1 \\
\end{tabular} & cf. & $\begin{array}{l}4 \\
4 \\
\end{array}$ & & 1 & $\begin{array}{l}1 \\
1 \\
\end{array}$ & 1 & 1 & 2 & \\
\hline & & CN10c & & $\begin{array}{l}6 \mathrm{H}-1,120 \\
6 \mathrm{H}-2,120 \\
6 \mathrm{H}-3,120 \\
6 \mathrm{H}-4,120\end{array}$ & $\begin{array}{l}49.9 \\
51.4 \\
52.9 \\
54.4\end{array}$ & $\begin{array}{l}3 \\
3 \\
5 \\
6\end{array}$ & & $\begin{array}{l}3 \\
2 \\
2 \\
2\end{array}$ & 5 & $\begin{array}{ll}4 & \\
4 & 1 \\
5 & \\
4 & 1 \\
\end{array}$ & & $\begin{array}{l}1 \\
1 \\
1\end{array}$ & 1 & $\begin{array}{l}1 \\
1 \\
1 \\
1 \\
\end{array}$ & \begin{tabular}{l|}
3 \\
4 \\
4 \\
3
\end{tabular} & & $\begin{array}{l}1 \\
2 \\
1 \\
3\end{array}$ & 1 & & $\begin{array}{l}2 \\
3\end{array}$ & $\begin{array}{l}2 \\
1\end{array}$ & $\begin{array}{l}4 \\
4\end{array}$ & $\begin{array}{l}3 \\
3\end{array}$ & $\begin{array}{l}3 \\
3 \\
\end{array}$ \\
\hline & & $\mathrm{CN} 10 \mathrm{a}-\mathrm{CN} 10 \mathrm{~b}$ & N18-N19 & $\begin{array}{l}6 \mathrm{H}-5,120 \\
6 \mathrm{H}-6,120 \\
7 \mathrm{H}-1,120 \\
7 \mathrm{H}-2,120\end{array}$ & $\begin{array}{l}55.9 \\
57.4 \\
59.5 \\
61.0\end{array}$ & $\begin{array}{l}5 \\
4 \\
6 \\
4\end{array}$ & $\begin{array}{l}1 \\
2\end{array}$ & $\begin{array}{l}1 \\
3 \\
1\end{array}$ & 5 & $\begin{array}{ll}4 & \\
5 & 1 \\
& 1 \\
5 & 1\end{array}$ & $\begin{array}{l}1 \\
4 \\
2 \\
3\end{array}$ & $\begin{array}{ll}1 & 1 \\
4 & \\
2 & \\
3 & \end{array}$ & & 4 & $\begin{array}{l}4 \\
2 \\
1 \\
2\end{array}$ & & $\begin{array}{ll}1 & 2 \\
4 & \\
4 & \\
4 & \end{array}$ & $\begin{array}{ll}2 & 1 \\
1 \\
1 \\
\\
& 4\end{array}$ & $\begin{array}{l}1 \\
1\end{array}$ & $\begin{array}{l}2 \\
1 \\
1 \\
1\end{array}$ & & 2 & 1 & \\
\hline Miocene & late & CN9 & $\mathrm{N} 17 \mathrm{~b}$ & $\begin{array}{l}7 \mathrm{H}-3,120 \\
7 \mathrm{H}-4,120 \\
7 \mathrm{H}-6,120 \\
8 \mathrm{H}-1,120 \\
8 \mathrm{H}-3,120 \\
8 \mathrm{H}-\mathrm{CC} \\
9 \mathrm{H}-4,120 \\
9 \mathrm{H}-6,120 \\
10 \mathrm{H}-1,120\end{array}$ & $\begin{array}{l}62.5 \\
64.0 \\
67.0 \\
69.2 \\
72.2 \\
77.5 \\
83.3 \\
86.3 \\
88.5 \\
\end{array}$ & $\begin{array}{l}4 \\
4 \\
3 \\
4 \\
5 \\
5 \\
4 \\
3 \\
4\end{array}$ & 1 & $\begin{array}{l}3 \\
1 \\
1 \\
3 \\
2\end{array}$ & $\begin{array}{ll} & 5 \\
1 & 5 \\
& 5 \\
3 & 5 \\
& 3 \\
& 4 \\
& 1 \\
& 1 \\
1 & 3\end{array}$ & $\begin{array}{ll}5 & 2 \\
5 & \\
5 & 1 \\
5 & \\
3 & \\
4 & 2 \\
1 & 3 \\
1 & 4 \\
3 & 2\end{array}$ & \begin{tabular}{l|l} 
& 4 \\
5 \\
6 \\
3 \\
2 \\
2 \\
1 \\
1 \\
1
\end{tabular} & $\begin{array}{ll}4 & \\
5 & \text { cf. } \\
6 & 2 \\
3 & \\
& 1 \\
2 & \\
1 & \\
1 & 2 \\
1 & \end{array}$ & $\begin{array}{l}1 \\
1 \\
1\end{array}$ & $\begin{array}{l}2 \\
5 \\
4 \\
2\end{array}$ & $\begin{array}{l}4 \\
5 \\
1 \\
2 \\
4 \\
4 \\
3\end{array}$ & cf. & $\begin{array}{l}1 \\
5 \\
2\end{array}$ & $\begin{array}{l}5 \\
4 \\
1\end{array}$ & & $\begin{array}{l}1 \\
3 \\
1 \\
2\end{array}$ & $\begin{array}{l}3 \\
2 \\
1\end{array}$ & $\begin{array}{l}3 \\
4 \\
4 \\
4 \\
5\end{array}$ & $\begin{array}{ll}3 & 4 \\
1 & \end{array}$ & \\
\hline
\end{tabular}

Note: Explanation as in Table 3. 
Table 20 (continued).

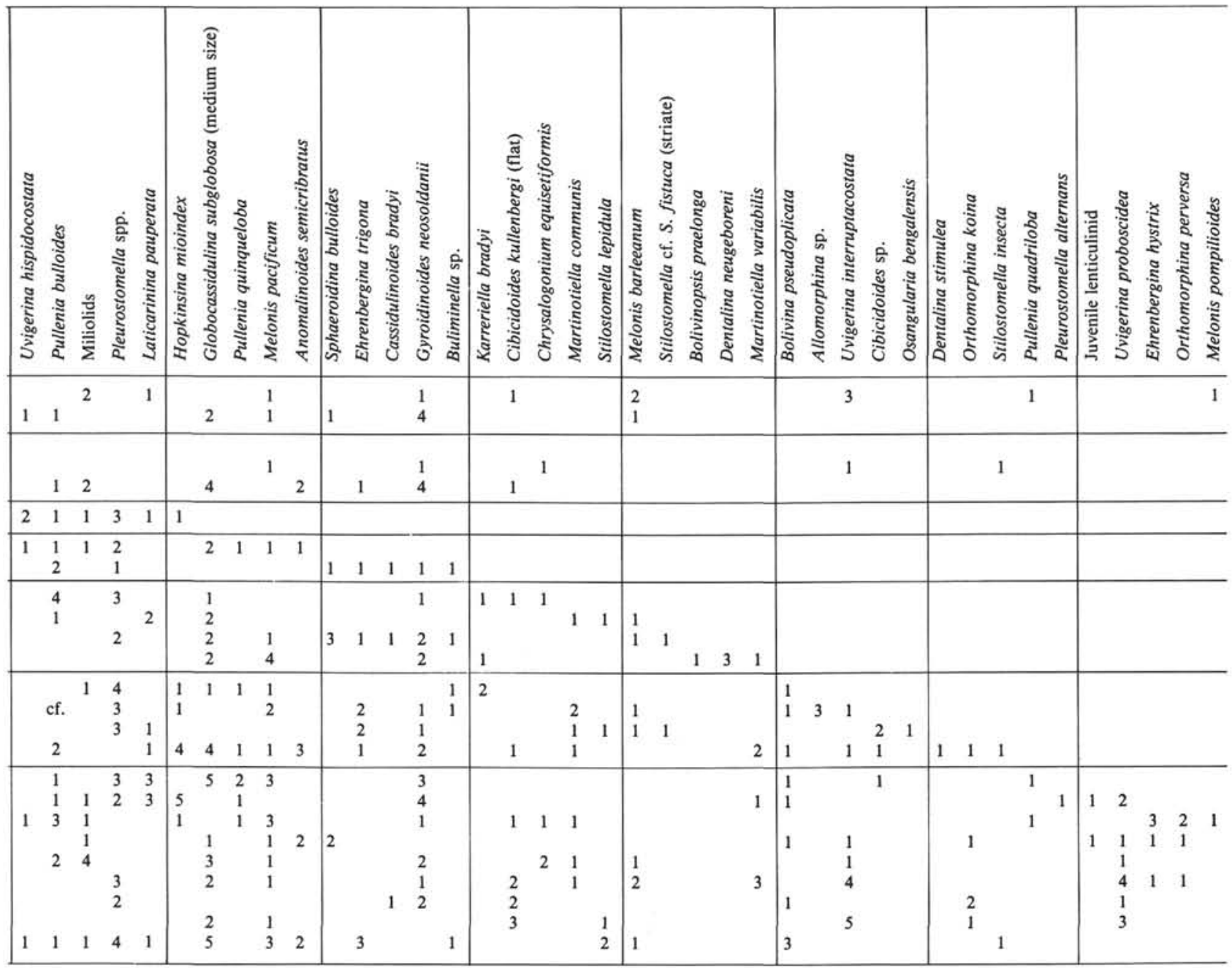


Table 20 (continued).

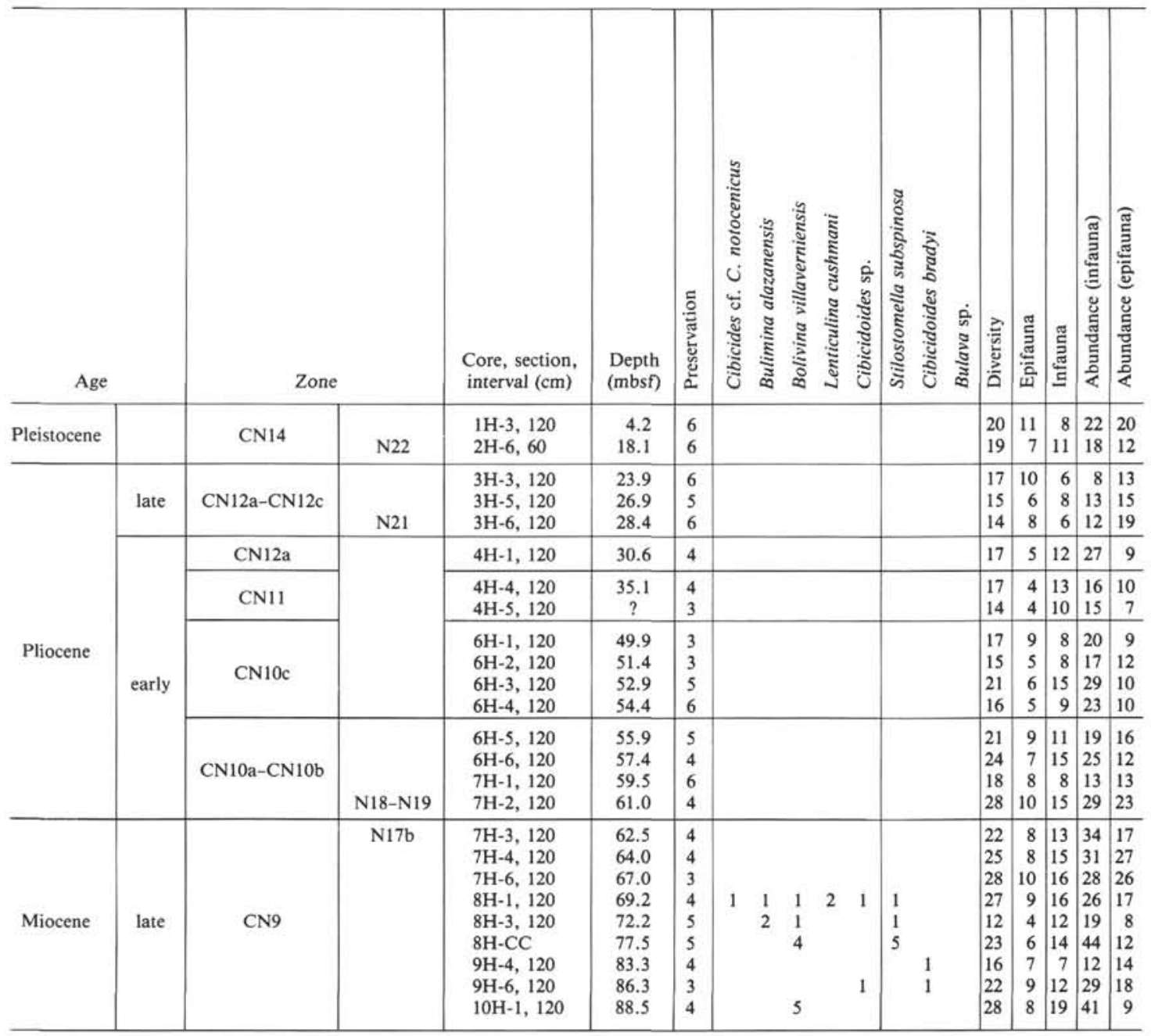



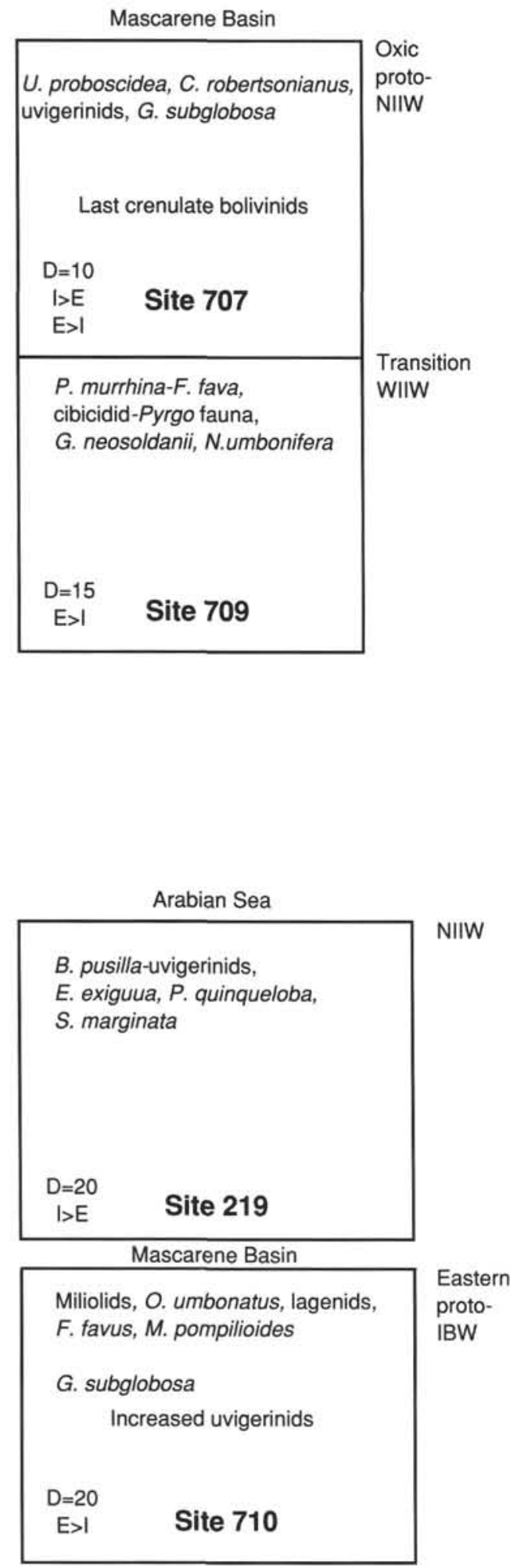

\begin{tabular}{|l|}
\hline \multicolumn{1}{|c|}{ Central Indian Basin } \\
M. pompilioides-F. fava \\
Miliolids, C. wuellerstorfi, \\
trifarinids \\
IDW \\
E>I Site 238 \\
\hline
\end{tabular}

Time slice

N21

Figure 16. Benthic foraminifer index faunas of late Pliocene Zone N21 (= Zone CN12) from five sites in the western and central Indian Ocean. Indexes, listed at top, were most abundant or most consistently present. Index forms that occurred only in pulses or events are shown below. Total sample diversity and the relation of infaunal to epifaunal abundance are shown at bottom left of each box. The faunal name assigned to each index fauna is listed to the right of each box. Data from Tables 15-19. 


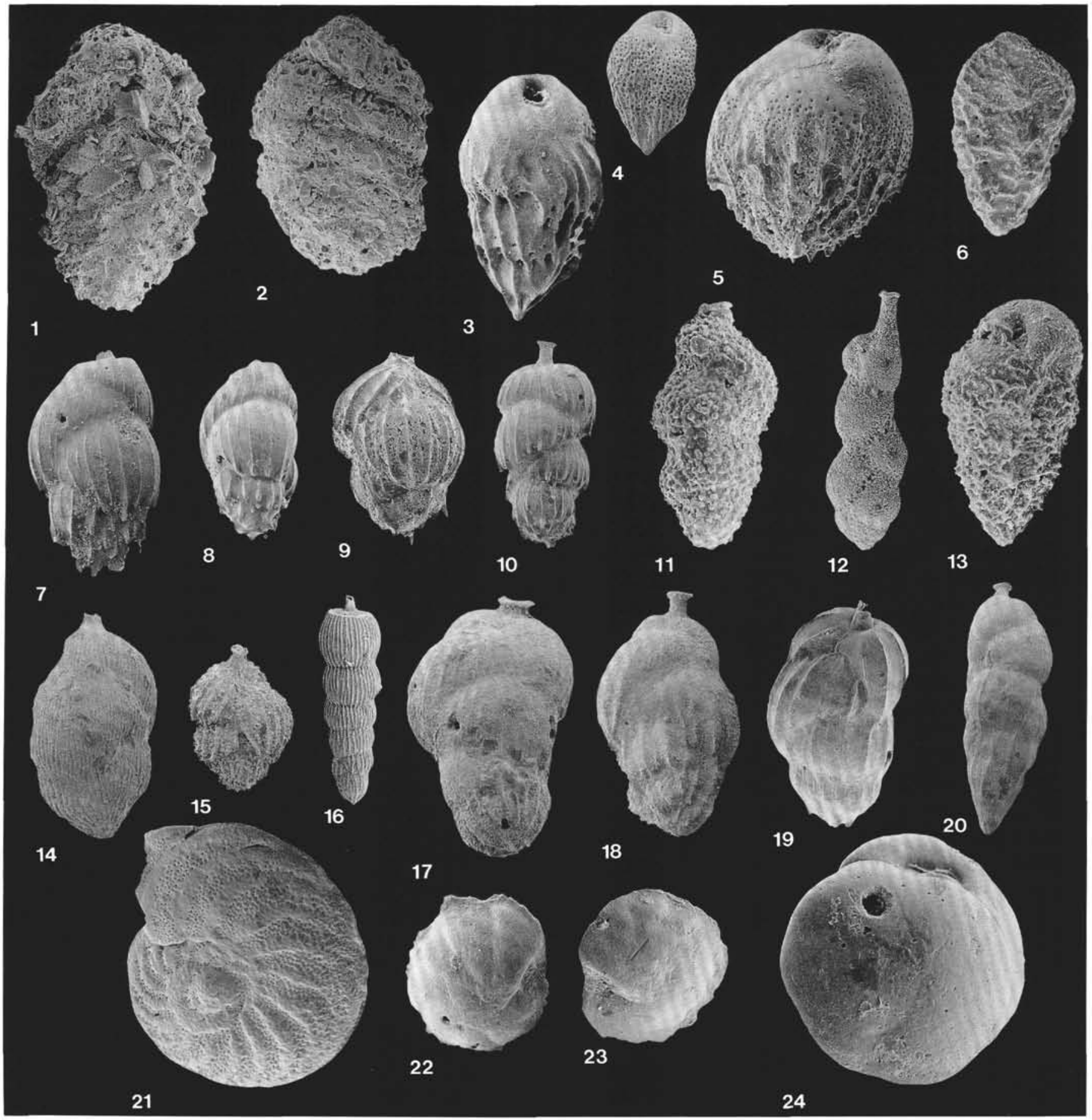

Plate 1. Benthic foraminifers typical at intermediate-depth Sites 707, 714, and 716. 1, 2. Textularia lythostrota Schwager; (1) Sample 115-707A$5 \mathrm{H}-\mathrm{CC}, \times 100$; (2) Sample 115-707A-2H-CC, $\times 100$. 3. Bulimina alazanensis Nuttall; Sample 115-707A-17H-CC. 4. Bulimina semicostata Nuttall; Sample 115-707A-17H-CC. 5. Bulimina mexicana Cushman; Sample 115-707A-5H-CC. 6. Bolivina pseudoplicata Herron-Allen and Earland; Sample 115-708A-11X-CC, $\times 200$; although this species is typical of intermediate depths, this specimen is probably redeposited downdepth to Site 708. 7, 8, 9, 10. Uvigerina spinulosa Hadley. (7) Sample 115-714A-23X-CC, $\times 100$. (8) Sample 115-707A-17H-CC, $\times 100$. (9) Sample 115707A-22X-5, $121 \mathrm{~cm}, \times 100$. (10) Sample 115-707A-11H-CC, $\times 100$. 11. Uvigerina sp.; Sample 115-714A-23X-CC, $\times 100$. 12. Uvigerina proboscidea Schwager; Sample 115-707A-11H-CC, $\times 100$. 13. Bolivina $\mathrm{cf}$. B. huneri Howe; Sample 115-707A-15H-CC, $\times 400$; although similar to the new genus, Abditodendrix, these heavily calcified forms lack the most distinctive feature of that genus, the truncated sides and rectangular cross-section; they are not strictly $B$. huneri, which is described as having delicate reticulation, but resemble $B$. cf. $B$. huneri, pictured by Tjalsma and Lohmann (1983). 14. Uvigerina flintii Cushman; Sample 115-716A-13H-CC, $\times 100$. 15. Uvigerina pigmea d'Orbigny; Sample 115-716A-13H-CC, $\times 100$. 16. Rectuvigerina striata (Schwager); Sample 115-716A-13H-CC, $\times 100$. 17. Uvigerina sp., possibly Uvigerina gemmaeformis Schwager; Sample 115-716A-13H-CC, $\times 100$. 18, 19, 20. Uvigerina schwageri Brady. (18) Sample 115-716A-26H-CC. (19) Sample 115-707A-5H-CC, $\times 100$. (20) Sample 115-716A-26H-CC, $\times 100$. 21. Planulina marialanna; Sample $115-707 \mathrm{~A}-11 \mathrm{H}-\mathrm{CC}, \times 50 . \quad$ 22. Osangularia bengalensis Schwager; Sample 115-709A-12H-CC, $\times 100$; note counterclockwise coiling of Miocene-age deep-water specimen from the Mascarene Basin. 23. Osangularia bengalensis Schwager; Sample 115-714A-23X-CC, $\times 200$; note smaller size and clockwise coiling of specimen from the latest Oligocene in the southern Indian upwelling zone. 24. Cassidulina crassa d'Orbigny; Sample 115-707A-15H-CC, $\times 200$. 


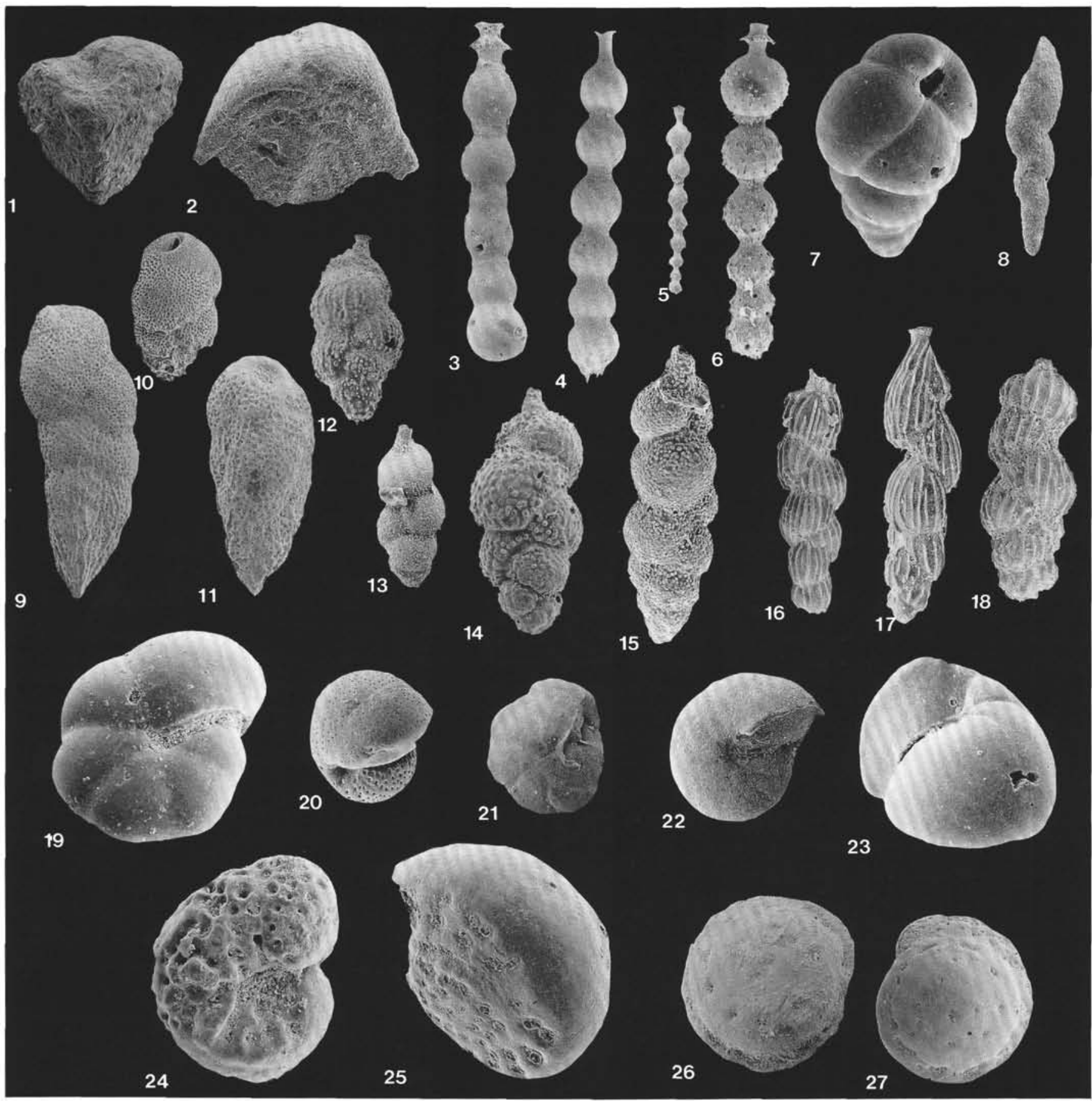

Plate 2. Typical lower bathyal and abyssal depth benthic foraminifers from Mascarene Basin Sites 708, 709, 710, and 711. 1. Gaudryina pyramidata Cushman; Sample 115-711A-21X-CC, $\times 100$. 2. Vulvulina spinosa Cushman; Sample 115-708A-20X-CC, $\times 100$. 3. Stilostomella nuttalli (Cushman and Jarvis); Sample 115-711A-21X-CC, $\times 100$. 4. Stilostomella insecta (Schwager); Sample 115-711A-8H-CC, $\times 100$. 5, 6. Stilostomella lepidula (Schwager). (5) Sample 115-711A-11 H-CC, $\times 50$. (6) Sample 115-709A-6H-CC, $\times 100$. 7. Buliminella sp.; Sample 115-709A-7H-CC, $\times 100$. 8. Pleurostomella alternans Schwager; Sample 115-711A-8H-CC, $\times 100$. 9, 11. Bulimina jarvisi Cushman and Parker. (9) Sample 115709C-29X-CC, $\times 100$. (11) Sample 115-709C-22X-CC, $\times 100$. 10. Bulimina macilenta Cushman and Parker; Sample 115-709A-6H-CC, $\times 100$. 12. Uvigerina hispidocostata Cushman and Todd; Sample 115-709A-4H-CC, $\times 100$. 13. Uvigerina sp.; Sample $115-710 \mathrm{~A}-2 \mathrm{H}-5,20 \mathrm{~cm}, \times 100$. 14. Uvigerina hispida Schwager; Sample $115-709 \mathrm{~A}-4 \mathrm{H}-\mathrm{CC}, \times 100$. 15. Uvigerina sp.; Sample 115-709A-9H-CC, $\times 100$. 16, 17. Hopkinsina mioindex Finlay. (16) Sample 115-709A-9H-CC, $\times 100$. (17) Sample 115-709A-4H-CC, $\times 100$. 18. Uvigerina spinicostata Cushman and Bermudez; Sample 115-709C-29X-CC, $\times 100$; this elongate specimen with few spines closely resembles the younger form, H. mioindex. 19. Pullenia quinqueloba (Reuss); Sample 115-711A-11H-CC, $\times 200$. 20. Melonis sphaeroides Voloshnaya; Sample 115-709A-9H-CC, $\times 100$. 21. Nuttallides umbonifera Cushman; Sample 115-710A-2H-5, $20 \mathrm{~cm}, \times 100$. 22. Gyroidinoides planulatus (Cushman and Renz); Sample 115-708A-20X-CC, $\times 100$. 23. Gyroidinoides soldanii (d'Orbigny); Sample $115-711 \mathrm{~A}-8 \mathrm{H}-\mathrm{CC}, \times 200$. 24. Anomalinoides aragonensis (Cole); Sample $115-711 \mathrm{~A}-21 \mathrm{X}-\mathrm{CC}, \times 100$. 25. Heterolepa grimsdalei (Nuttall); Sample 115-710A-17X-CC, $\times 100,26,27$. Cibicidoides havanensis (Cushman and Bermudez). (26) Sample 115-711A-7H-CC, $\times 100$. (27) Sample 115-709C-22X-CC, $\times 50$. 